\title{
Nederland in leerstand
}

Citation for published version (APA):

Fouarge, D., van Eldert, P., de Grip, A., Künn, A., \& Poulissen, D. (2018). Nederland in leerstand. ROA. ROA Reports No. 004 https://doi.org/10.26481/umarep.2018004

Document status and date:

Published: 01/01/2018

DOI:

10.26481/umarep.2018004

Document Version:

Publisher's PDF, also known as Version of record

\section{Please check the document version of this publication:}

- A submitted manuscript is the version of the article upon submission and before peer-review. There can be important differences between the submitted version and the official published version of record.

People interested in the research are advised to contact the author for the final version of the publication, or visit the DOI to the publisher's website.

- The final author version and the galley proof are versions of the publication after peer review.

- The final published version features the final layout of the paper including the volume, issue and page numbers.

Link to publication

\footnotetext{
General rights rights.

- You may freely distribute the URL identifying the publication in the public portal. please follow below link for the End User Agreement:

www.umlib.nl/taverne-license

Take down policy

If you believe that this document breaches copyright please contact us at:

repository@maastrichtuniversity.nl

providing details and we will investigate your claim.
}

Copyright and moral rights for the publications made accessible in the public portal are retained by the authors and/or other copyright owners and it is a condition of accessing publications that users recognise and abide by the legal requirements associated with these

- Users may download and print one copy of any publication from the public portal for the purpose of private study or research.

- You may not further distribute the material or use it for any profit-making activity or commercial gain

If the publication is distributed under the terms of Article $25 \mathrm{fa}$ of the Dutch Copyright Act, indicated by the "Taverne" license above, 


\title{
Maastricht University $\quad \mathrm{ROA}$
}

\section{Nederland in leerstand}

\section{ROA Rapport}

\author{
ROA-R-2018/4
}

Researchcentrum voor Onderwijs en Arbeidsmarkt | ROA Research Centre for Education and the Labour Market / ROA 


\section{NEDERLAND IN LEERSTAND}

ROA-R-2018/4

Didier Fouarge

Peter van Eldert

Andries de Grip

Annemarie Künn-Nelen

Davey Poulissen 


\title{
Colofon
}

(C) Researchcentrum voor Onderwijs en Arbeidsmarkt (ROA). Niets uit deze uitgave mag op enige manier worden verveelvoudigd zonder voorafgaande schriftelijke toestemming van de directeur van het ROA.

\author{
Researchcentrum voor Onderwijs en Arbeidsmarkt \\ Postbus 616 \\ 6200 MD Maastricht \\ $\mathrm{T}+31433883647$ \\ $\mathrm{F}+31433884914$ \\ secretary-roa-sbe@maastrichtuniversity.nl \\ www.roa.nl
}

School of Business and Economics

Maastricht University

\section{Vormgeving}

ROA secretariaat, Maastricht

ISBN: 978-90-5321-567-8

mei 2108

\section{NR@)}

Dit rapport maakt onderdeel uit van het NRO project 'Levenslang leren en competentieontwikkeling' (dossiernummer 405-16-402). 


\section{INHOUD}

Voorwoord

Resumé

vii

1 Trends in het leren in Nederland $\quad 1$

$\begin{array}{lll}1.1 & \text { Ontwikkelingen in de cursusdeelname } & 1\end{array}$

1.2 Ontwikkelingen in informeel leren op het werk 10

1.3 Leren buiten het werk 17

1.4 Bruikbaarheid van formeel en informeel leren voor de loopbaan 21

1.5 Trends in de kennisontwikkeling 23

2 Taken en leren op het werk 27

$\begin{array}{ll}2.1 & \text { Leren en het belang van taken op het werk }\end{array}$

2.2 Multivariate analyses 32

3 Leren, externe employability en mobiliteit 41

3.1 Ontwikkelingen in externe employability en mobiliteit 41

3.2 Informeel en formeel leren in relatie tot externe employability en mobiliteit 49

Literatuur

59

Bijlage A

61

Bijlage B

69 


\section{VOORWOORD}

De Nederlandse overheid ervaart het als zeer urgent een goed levenslang leren beleid te ontwikkelen dat onze kenniseconomie een impuls geeft. Daarbij staan twee aan elkaar gerelateerde vragen centraal:

- Over welke competenties moet de (vergrijzende) Nederlandse beroepsbevolking beschikken?

- Hoe kan de scholing en het informeel leren dat daarvoor nodig is worden gestimuleerd?

Het NRO project Levenslang Leren en competentieontwikkeling (405-16-402) richt zich op het beantwoorden van deze twee vragen.'

Het doel van levenslang leren is het op peil houden en vergroten van iemands competenties zodat iedereen inzetbaar blijft op de arbeidsmarkt. Echter, de vraag naar competenties is veranderlijk. Ook kunnen niet alle competenties op eenzelfde manier verworven worden en zijn bepaalde leervormen voor specifieke groepen juist meer of minder geschikt (zie Künn-Nelen et al., 2018). In dit rapport staat de relatie tussen de gevraagde competenties, de deelname aan scholing en informeel leren en iemands loopbaan centraal. Eerst schetsen wij een beeld van de ontwikkeling in levenslang leren activiteiten in de periode 2004-2017. Daarna gaan wij op de relatie tussen deelname aan scholing en informeel leren en de competenties van de beroepsbevolking en ten slotte beschrijven we de betekenis van verschillende vormen van levenslang leren voor iemands loopbaan en externe employability. In het rapport zal nog niet worden ingegaan op de beleidsimplicaties van het onderzoek. Hierop zal worden ingegaan in het samenvattende Beleidsrapport Levenslang leren en competentieontwikkeling.

Het onderzoek is uitgevoerd aan de hand van data uit de ROA Levenslang Leren Enquête en de Nederlandse Skills Survey. In februari 2017 vond de vijfde meting van de ROA Levenslang Leren Enquête plaats. Deze meting is een voortzetting van eerdere metingen (in 2004, 2007, 2010 en 2013) met een aantal toevoegingen, waaronder vragen gericht op het informeel leren buiten het werk (bijvoorbeeld bij het doen van vrijwilligerswerk). De Nederlandse Skills Survey is in 2012 en 2017 gehouden met het oog op het meten van

$1 \quad$ Zie de ROA website voor meer informatie: http://roa.sbe.maastrichtuniversity.nl/?port-folio=roa-lifelong-learning-survey 
het belang van de taken en vaardigheden van werkenden. Doordat de 2017 peiling van de ROA Levenslang Leren Enquête en de Nederlandse Skills Survey beide gehouden zijn onder respondenten van het LISS panel kunnen beide databronnen op individueel niveau worden gekoppeld. Dit geeft een unieke kans om de relatie te leggen tussen het niveau van competenties van werkenden en de levenslang leren activiteiten die zij ondernemen.

Wij danken de leden van Klankbordgroep (Dirk Scheele, Ans Harthoorn, André de Moor, Brigid Claassen, Jonneke Bolhaar) en Bas ter Weel voor hun waardevol commentaar. Dit rapport maakt onderdeel uit van het NRO project 'Levenslang leren en competentieontwikkeling' (dossiernummer 405-16-402).

Prof. dr. Andries de Grip

Directeur ROA 


\section{RESUMÉ}

In dit rapport staan de trends en ontwikkelingen in het levenslang leren onder werkenden en niet-werkenden centraal. Hierbij besteden wij zowel aandacht aan het formele leren, het informele leren van taken op het werk en het leren buiten het werk als gevolg van uiteenlopende activiteiten. Daarnaast leggen wij de relatie tussen het leren en de taken van werkenden. Ten slotte besteden we aandacht aan het beeld dat de verschillende groepen werkenden hebben van hun externe employability en de kans op baanverlies. De belangrijkste bevindingen uit dit rapport laten zich als volgt samenvatten:

De gemiddelde cursusdeelname is stabiel, maar wederom groeit de kloof tussen hoog- en laagopgeleiden en neemt de intensiteit van cursussen af.

- Ruim de helft (54\%) van de werkenden heeft in de afgelopen twee jaar een cursus gevolgd. Ruim driekwart van de cursussen leidt tot een diploma of certificaat. Hiervan wordt 70 procent ook erkend door een nationaal of internationaal orgaan. Zowel de directe als indirecte kosten van de cursus of training komen meestal voor rekening van de werkgever.

- De gemiddelde cursusduur gemeten in dagen is sinds 2004 afgenomen.

- Sinds 2004 is de kloof in de cursusdeelname tussen jong en oud afgenomen, maar tussen laag- en hoogopgeleiden is de kloof toegenomen.

- Hoogopgeleiden volgen ook cursussen die gemiddeld genomen langer duren dan laag- of middelbaar opgeleiden.

- Middelbaar opgeleiden ronden een cursus het vaakst af met een diploma of certificaat terwijl hoogopgeleiden vaker een cursus volgen waarvoor geen diploma of certificaat behaald kon worden. Wanneer een cursus wordt afgerond met een diploma of certificaat blijkt dat deze het vaakst erkend is door een nationaal of internationaal orgaan onder laagopgeleiden.

- In de sectoren financiële instellingen en zakelijke dienstverlening, overheidsdiensten en openbaar bestuur, gezondheids- en welzijnszorg is de cursus-/trainingsparticipatie het hoogst en in de sector handel het laagst.

- Hoogopgeleiden nemen vaker zelf het initiatief tot scholing; voor lager opgeleiden komt het initiatief juist vaker van de werkgever.

- 70 procent van de werkenden kan de opgedane kennis goed in praktijk brengen. Bovendien profiteren bij 46 procent van de gevolgde cursussen ook de collega's die de cursus zelf niet hebben gevolgd (kennisoverdracht op de werkvloer). 
Hoewel het grootste deel van de totale leertijd op het werk betrekking heeft op informele leeractiviteiten, is de mate waarin werkenden informeel leren op het werk in de periode 20042017 afgenomen.

- Het informeel leren van taken op het werk is afgenomen van 31 procent in 2010 naar 24 procent in 2017. Desalniettemin blijft de tijd die besteed wordt aan leerzame taken een belangrijke plaats in nemen in de totale tijd waarin men leert: slechts 15 procent van de totale leertijd op het werk heeft betrekking op het leren van cursussen, terwijl $85 \%$ van het leren het gevolg is van informele leeractiviteiten.

- De sectoren met het hoogste percentage informeel leren van de taken op het werk zijn het onderwijs en de financiële instellingen en zakelijke dienstverlening.

- In grote bedrijven ligt de cursusdeelname hoger dan in kleine bedrijven. Daar staat tegenover dat het informeel leren van taken op het werk onafhankelijk is van de grootte van het bedrijf.

- Anciënniteit hangt negatief samen met de mate waarin werkenden informeel leren, terwijl veranderingen van functie (bij dezelfde werkgever) of veranderingen van baan positief samenhangen met de mate van informeel leren.

- Werkenden geven aan even veel te leren van 1 uur informeel leren op het werk als van 1 uur formeel leren. Omdat werkenden door de bank genomen meer tijd besteden aan taken waarvan ze leren dan aan cursussen/trainingen kunnen we concluderen dat de doorsnee werknemer in totaal meer leert van de taken die men uitvoert dan van de cursussen die men volgt.

Mensen leren uiteraard niet alleen door scholing of van de taken die zij uitvoeren op hun werk. Men leert ook van allerhande andere activiteiten zoals zelfstudie, tijd met kinderen, e.d.

- Bijna de helft (48\%) van de werkenden doet thuis aan zelfstudie. Maar de tijd die hieraan wordt besteed is betrekkelijk kort: gemiddeld 3 uur per maand.

- Niet-werkenden besteden procentueel meer tijd aan informeel leren buiten het werk dan werkenden.

- Als het leren van taken op het werk buiten beschouwing wordt gelaten leren zowel werkenden als niet-werkenden het meeste van tijd met kinderen. Niet-werkenden leren echter aanzienlijk meer van vrijwilligerswerk en mantelzorg waar werkenden juist meer leren van cursussen.

- De bruikbaarheid op de arbeidsmarkt van het informeel leren buiten het werk door werkenden is echter relatief laag.

Het formele en informele leren alsook de kennisontwikkeling blijken sterk afhankelijk te zijn van het takenpakket dat iemand heeft en de veranderingen die plaatsvinden op het werk.

- Werkenden gaven aan dat het niveau van hun kennis en vaardigheden in de afgelopen 2 jaar 9 procentpunt dichter in de buurt is gekomen van het niveau dat nodig is om optimaal in hun werk te functioneren. Deze kennisontwikkeling ligt hoger dan inde voorgaande jaren. 
- De kennisontwikkeling in de afgelopen twee jaar neemt af naarmate de leeftijd toeneemt; desondanks ontwikkelen 50-plussers zich sterker dan in de voorgaande jaren.

- Rekenvaardigheden worden het minst vaak genoemd als belangrijke taak op het werk. Probleemoplossend vermogen daarentegen juist het meest.

- lemands leergedrag (cursusdeelname, informeel leren) en kennisontwikkeling ligt doorgaans op een hoger niveau als interpersoonlijke vaardigheden, taalvaardigheden en probleemoplossend vermogen belangrijke taken op het werk zijn.

- Hoe groter de veranderingen op het werk hoe hoger de cursusdeelname en het informeel leren van taken op het werk.

- Hoe belangrijker interpersoonlijke vaardigheden, taalvaardigheden en probleemoplossend vermogen voor het werk zijn, hoe groter de kans dat de werkende een cursus heeft gevolgd. De cursusdeelname neemt ook toe als de organisatorische veranderingen binnen het bedrijf groter zijn.

- Ook als er wordt gekeken naar het belang van iemands taken enkele jaren geleden, dan blijken werkenden in banen waarvoor interpersoonlijke vaardigheden en taalvaardigheden belangrijk zijn vaker een cursus te volgen. Ook volgen werkenden die te maken hebben met organisatorische ontwikkelingen op het werk vaker een cursus dan werkenden waarvoor dat niet het geval is.

- Interpersoonlijke vaardigheden en taalvaardigheden hangen positief samen met het informeel leren op het werk. Werkenden die te maken hebben met grote technologische of organisatorische ontwikkelingen leren ook significant meer van hun werkzaamheden.

- De taken die iemand uitoefent hebben geen effect op iemands kennisontwikkeling in de afgelopen twee jaar. Meer concurrentie op de afzetmarkt van het bedrijf zorgt daarentegen wel voor een grotere kennisontwikkeling.

- lemands kennisontwikkeling is groter als de betreffende persoon in het verleden taken heeft uitgevoerd waarvoor taalvaardigheden of plannen en organiseren belangrijk waren. Wanneer het gebruik van computers belangrijk was in 2012 is de kennisontwikkeling in de jaren daarna juist lager.

- De kennisontwikkeling is groter als werkenden van baan veranderen. Dit suggereert dathetveranderenvanwerktaken werkenden stimuleertomnieuwekennisoptedoen.

Het beeld dat werkenden hebben van hun externe employability en mobiliteit blijkt sterk afhankelijk te zijn van achtergrondkenmerken en leergedrag.

- De externe employability en baanzekerheid werden tijdens de crisisjaren 2010 en 2013 op een lager niveau ingeschat dan in de jaren daarvoor. De externe employability ligt in 2017 nog op hetzelfde niveau als in 2013, maar de kans op baanverlies wordt in 2017 weer lager ingeschat.

- Het risico op baanverlies wordt hoger ingeschat als iemand werkzaam is in een beroep met een groter automatiseringsrisico. 
- De kloof in gepercipieerde externe employability tussen hoog-en laagopgeleiden is tussen 2004 en 2017 gegroeid. Ouderen schatten hun externe employability lager in dan jongeren, maar het verschil tussen jong en oud wordt kleiner.

- Werkenden in de sector landbouw schatten hun externe employability het laagst in; werkenden in de sector zakelijke dienstverlening het hoogst. Werkenden in de sector financiële instellingen en zakelijke dienstverlening schatten de kans op baanverlies het hoogste in. Overheidsdiensten en openbaar bestuur en onderwijs zijn de sectoren waarin de werkenden juist het meest positief zijn over hun eigen baanzekerheid.

- In alle sectoren schatten laagopgeleiden hun externe employability het laagst in en hoogopgeleiden juist het hoogst. De hoge externe employability van de werkenden in de sectoren financiële instellingen en zakelijke dienstverlening en het onderwijs is daardoor gerelateerd aan de oververtegenwoordiging van hoogopgeleiden in deze sectoren.

- Het informeel leren buiten het werk, in de vorm van vrijwilligerswerk, mantelzorg, tijd met kinderen of zelfstudie heeft geen relatie met iemands gevoel van externe employability.

- Daar staat tegenover dat werkenden die een cursus hebben gevolgd een positiever beeld hebben van hun eigen externe employability en denken minder risico te lopen op baanverlies. Een hoog percentage informeel leren op het werk speelt geen verklarende rol voor iemands externe employability en kans op baanverlies als er gecontroleerd wordt voor achtergrondkenmerken.

- Bij grote organisatorische ontwikkelingen op het werk en een sterke instabiliteit op de markt hebben werkenden een negatiever beeld van hun externe employability.

- Technologische ontwikkelingen op het werk verlagen het geschatte risico op baanverlies terwijl organisatorische ontwikkelingen deze juist verhogen. Degenen die werkzaam zijn in een organisatie die actief is op een meer onzekere afzetmarkt schatten het risico op baanverlies ook hoger in.

- Ongeacht welke cursus iemand gevolgd heeft, wordt het risico op baanverlies lager ingeschat dan door werkenden die geen cursus hebben gevolgd. De enige uitzondering is een cursus die alleen relevant is voor een loopbaan buiten het bedrijf; dan is het gepercipieerd risico op baanverlies wel hoger. Een mogelijke verklaring is dat een cursus die alleen bedoeld is om de externe employability te verhogen, gevolgd wordt als men anticipeert op een dreigend baanverlies.

- Werkenden die een cursus hebben gevolgd verwachten een halfjaar later met pensioen te gaan dan werkenden die geen cursus hebben gevolgd. De hogere verwachte pensioenleeftijd wordt gedreven door cursussen die zowel binnen als buiten het bedrijf bruikbaar zijn, gevolgd zijn om loopbaandoelen te realiseren of gericht op vaktechnische kennis en vermogen of digitale vaardigheden. 


\section{TRENDS IN HET LEREN IN NEDERLAND}

In dit hoofdstuk geven wij een overzicht van de trendmatige ontwikkeling in het formeel en informeel leren tussen 2004 en 2017. Hierbij ligt de focus op een totaal overzicht van de ontwikkelingen. Een uitsplitsing naar specifieke groepen - opleidingsniveau, leeftijd en soort contract - komt in meer detail aan bod in het rapport Leren onder werkenden met een kwetsbare positie op de arbeidsmarkt (Künn-Nelen et al., 2018). De data is afkomstig van de ROA Levenslang Leren Enquête 2004, 2007, 2010, 2013 en 2017, waarbij in verband met de vergelijkbaarheid in de tijd, de kernvragen onveranderd zijn gebleven. Bijlage A geeft een beschrijving van de data.

Paragraaf 1.1 gaat in op de ontwikkelingen in de cursusdeelname uitgesplist naar achtergrondkenmerken. Daarna brengt paragraaf 1.2 de ontwikkeling van het informele leren op het werk in kaart. Vervolgens gaat paragraaf 1.3 in op de verschillende vormen van informeel leren buiten het werk. Tot slot laat paragraaf 1.4 de trends zien in de kennisontwikkeling, als gevolg van de participatie in het formeel en informeel leren.

\subsection{Ontwikkelingen in de cursusdeelname}

\section{Deelname aan trainingen en cursussen}

Om de cursusdeelname in kaart te brengen zijn de respondenten iedere meting gevraagd of zij in de afgelopen twee jaar een cursus of training hebben gevolgd. Het gaat hierbij om cursussen die voor het werk relevant zijn, waarbij pure hobbycursussen (bijvoorbeeld bridge, schilderen) buiten beschouwing worden gelaten. Figuur 1.1 laat zien wat de ontwikkeling is geweest in de cursusdeelname in de periode 2004-2017. Daarbij wordt een onderscheid gemaakt tussen werkenden en niet-werkenden (exclusief studenten). ${ }^{2}$ De figuur laat zien dat er in de afgelopen 13 jaar weinig veranderingen hebben plaatsgevonden in de cursusdeelname. In 2017 gaf ruim de helft (54\%) van de werkenden aan in de afgelopen twee jaar een training of cursus te hebben gevolgd, en dat percentage is vergelijkbaar met dat in eerdere jaren. ${ }^{3}$

2 De definitie van werkenden in dit hoofdstuk gaat uit van de belangrijkste bezigheid van respondenten in de leeftijd 16-67 jaar, ongeacht het aantal gewerkte uren: 1) betaald werk in loondienst, 2) werkzaam of meewerkend in een gezins- of familiebedrijf 3) vrije beroepsbeoefenaar, freelancer of zelfstandige. Niet-werkenden zijn personen die niet in een van deze drie categorieën vallen.

3 Daarnaast volgt 2,6\% van de werkende 35-plussers momenteel een volledige opleiding op een middelbare school (bijv. vmbo, havo, vwo), of in het middelbaar beroepsonderwijs, hoger beroepsonderwijs of de universiteit. 
54 procent van de werkenden heeft in de afgelopen twee jaar een cursus gevolgd.
Daar tegenover staat een aanmerkelijk lagere cursusdeelname onder de niet-werkenden (20\%) dan onder werkenden. De cursusdeel-

name onder niet-werkenden lag in 2007 op een iets lager niveau, om in de jaren daarna te herstellen naar relatief stabiel niveau over tijd. In het kader van de toenemende dynamiek op de arbeidsmarkt is het vooral zorgelijk dat 28 procent van de werkenden nog nooit een cursus heeft gevolgd (Büyükkeçeci et al., 2017). Dit roept de vraag op in welke mate deze personen in staat zijn veranderingen in de gevraagde vaardigheden bij te houden.

Ruim driekwart van de cursussen leidt tot een diploma of certificaat. Hiervan is 70 procent ook erkend door een nationaal of internationaal orgaan.
Van de respondenten die aangeven een cursus of training te hebben gevolgd rondde in 201779 procent deze ook af met een diploma. Ten opzichte van 2013 is dat een stijging van 7 procentpunten. Het percentage van de respondenten dat aangaf dat er bij de cursus geen diploma of certificaat te halen is namelijk met 6 procentpunt afgenomen, van 27 naar 21 procent. De overige 1 procent had de mogelijkheid om een diploma te halen maar heeft dit diploma niet behaald. De ontwikkeling tussen 2013 en 2017 is overigens voor zowel werkenden als niet-werkenden hetzelfde. Echter, het percentage dat een diploma of certificaat had behaald lag hoger onder werkenden (79\%) dan onder niet-werkenden (73\%). Niet-werkenden volgden vaker een cursus waarvoor geen diploma behaald kon worden. Naast het al dan niet behalen van een diploma is het ook de vraag of het behaalde diploma een erkend diploma is. Dit blijkt voor het merendeel van de behaalde diploma's het geval te zijn: 70 procent van de diploma's die werkenden hebben behaald is erkend door een nationaal of internationaal orgaan. Voor niet-werkenden is dit $75 \%$. 
FIGUUR 1.1 Formeel leren: ontwikkeling van de deelname aan cursussen en trainingen, 2004-2017

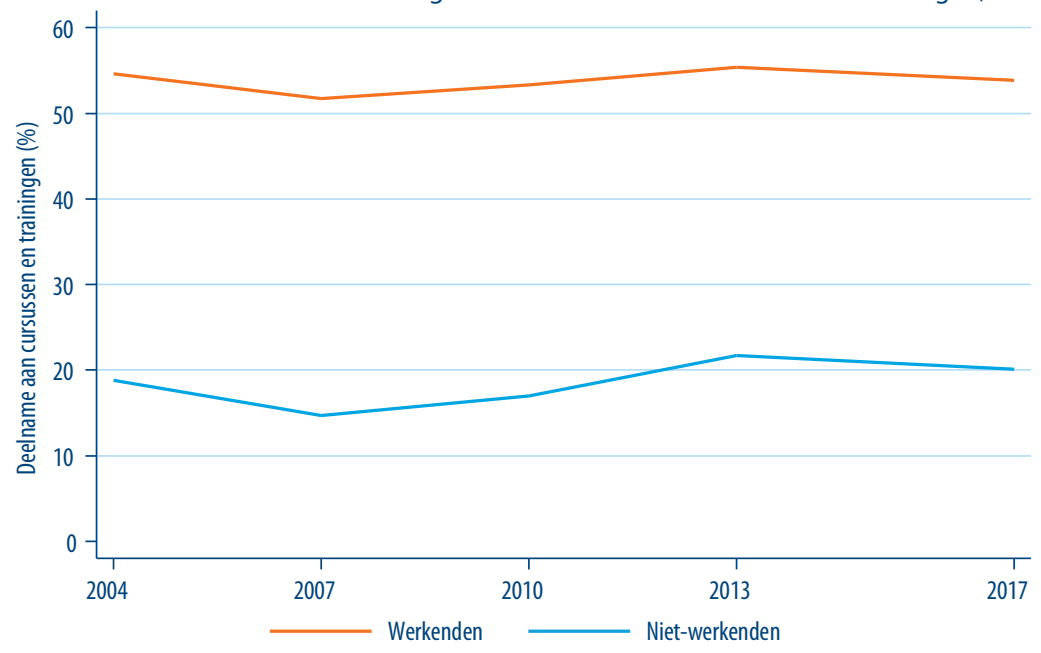

Bron: ROA LLL enquête, 2004-2017

\section{Cursusdeelname naar opleidingsniveau}

De kloof in cursusdeelname tussen laagen hoogopgeleiden groeit.
In Figuur 1.2 wordt de ontwikkeling in de cursusdeelname onder werkenden tussen 2004 en 2017 gedifferentieerd naar oplei-

dingsniveau. ${ }^{4}$ Hoogopgeleiden volgden in 2017 significant vaker een cursus (63\%) dan laagopgeleiden (39\%). De cursusdeelname onder middelbaar opgeleiden lag met 53 procent daar tussen in. Tot en met 2010 lag de cursusdeelname van laag- en middelbaar opgeleiden ongeveer op hetzelfde niveau. In 2013 ontstond er echter een kloof tussen beide opleidingsniveaus, vooral doordat de cursusdeelname van laagopgeleiden ongeveer 10 procentpunt daalde tot 37 procent en de cursusdeelname onder middelbaar opgeleiden met 6 procentpunt steeg. Ook de kloof in cursusdeelname tussen hoog-en laagopgeleiden blijkt te groeien (zie Fouarge et al., 2013; Künn-Nelen et al., 2018). 
FIGUUR 1.2 Formeel leren: ontwikkeling van deelname aan cursussen en trainingen door werkenden naar opleidingsniveau, 2004-2017

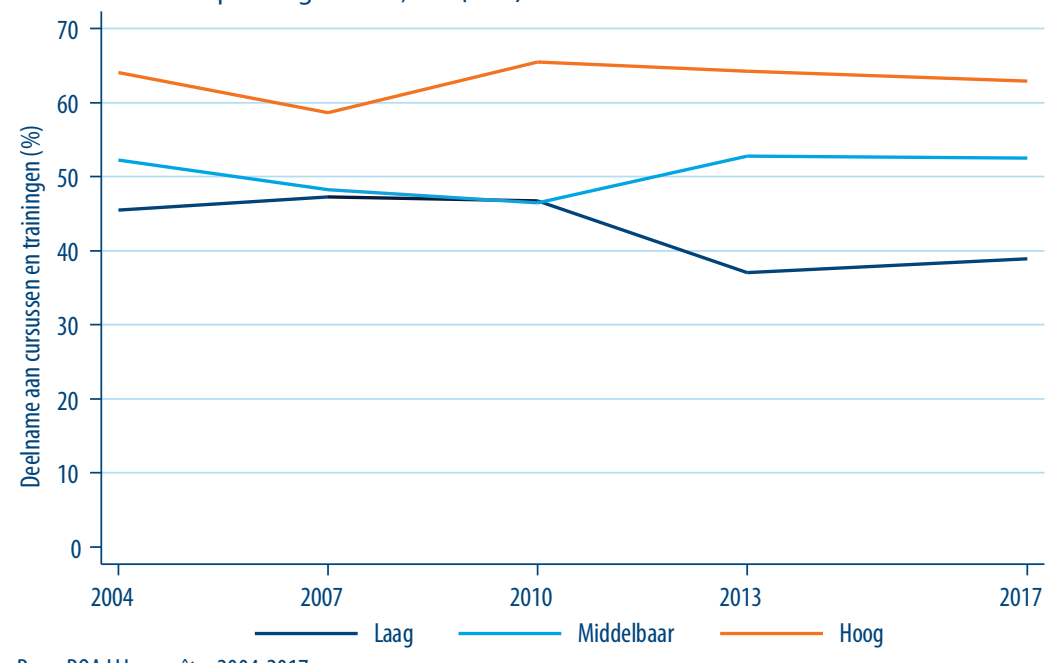

Bron: ROA LLL enquête, 2004-2017

Middelbaar opgeleiden ronden een cursus vaker af met een diploma of certificaat. Laagopgeleiden behalen vaker een erkend diploma.
Hoewel hoogopgeleiden vaker een cursus of training volgen, zijn het juist vaker de middelbaar opgeleiden die een gevolgde cursus ook afronden met een diploma of certificaat. Hoogopgeleiden volgen vaker een cursus waarvoor geen diploma of certificaat behaald kon worden. Wanneer een cursus wordt afgerond met een diploma of certificaat, dan blijkt dat dit diploma bij laagopgeleiden vaker erkend is door een nationaal of internationaal orgaan, dan bij middelbaar of hoger opgeleiden. Een mogelijke verklaring hiervoor zou kunnen zijn dat laagopgeleiden vaker werkzaam zijn in beroepen waarin certificering noodzakelijk is, bijvoorbeeld in het kader van ISO-kwaliteitseisen.

\section{Cursusdeelname naar sector}

In de sectoren financiële instellingen en zakelijke dienstverlening, overheidsdiensten en openbaar bestuur, gezondheidsen welzijnszorg en onderwijs wordt relatief vaak deelgenomen aan een cursus of training. In de sector handel is de cursusdeelname het laagst.
Het deelnemen aan cursussen of trainingen is niet in alle sectoren even gebruikelijk, omdat de noodzaak tot bijscholing sterk verschilt tussen sectoren (Bapna et al., 2013). Dit is goed terug te zien in Figuur 1.3, waarin de uitsplitsing in cursusdeelname onder werkenden naar sector wordt weergegeven op basis van de peiling van 2017. In de sector handel heeft minder dan 40 procent van de werkenden in de afgelopen twee jaar een cursus of training gevolgd. Daarentegen zijn er vier sectoren waar de cursusdeelname 
hoger ligt dan 60 procent, namelijk de sectoren financiële instellingen en zakelijke dienstverlening, overheidsdiensten en openbaar bestuur, gezondheids- en welzijnszorg en onderwijs. Het percentage werkenden dat heeft deelgenomen aan een cursus of training in de afgelopen 2 jaar ligt in de sector onderwijs zelfs bijna twee keer zo hoog als de cursusdeelname binnen de sector handel. Met name in de bouw en de gezondheids- en welzijnszorg hebben de gevolgde cursussen vaak een verplicht karakter.

FIGUUR 1.3 Formeel leren: deelname aan cursussen en trainingen door werkenden en verplichte karakter van de cursus naar sector, 2017

(a) Cursus gevolgd (\%)

(b) Verplichte cursussen onder de gevolgde cursussen (\%)

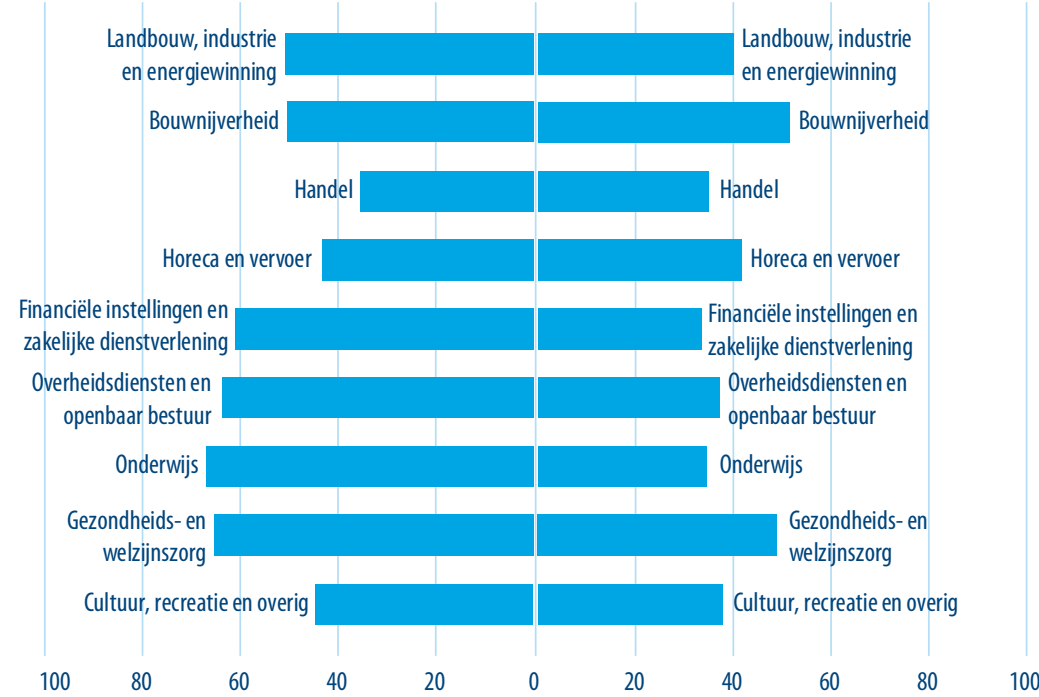

Bron: ROA LLL enquête, 2004-2017

\section{Cursusdeelname naar leeftijd}

De cursusdeelname door werkenden wordt in Figuur 1.4 naar leeftijd uitgesplitst. Hieruit blijkt dat onder de werkenden zowel jongeren als ouderen in de laatste twee metingen meer cursussen en trainingen zijn gaan volgen (Künn-Nelen et al., 2018). Hierdoor worden de verschillen in cursusdeelname naar leeftijd steeds kleiner. De kloof in cursusdeelname tussen 55-plussers en jongere werkenden neemt significant af, ook als er gecontroleerd wordt voor geslacht en opleidingsniveau. In eerder onderzoek hebben wij laten zien dat de versobering van pensioenregelingen een aannemelijke verklaring is voor de toename in de scholingsdeelname van oudere werkenden (Fouarge \& de Grip, 2014). 
FIGUUR 1.4 Formeel leren: ontwikkeling van deelname aan cursussen en trainingen door werkenden naar leeftijd, 2004-2017

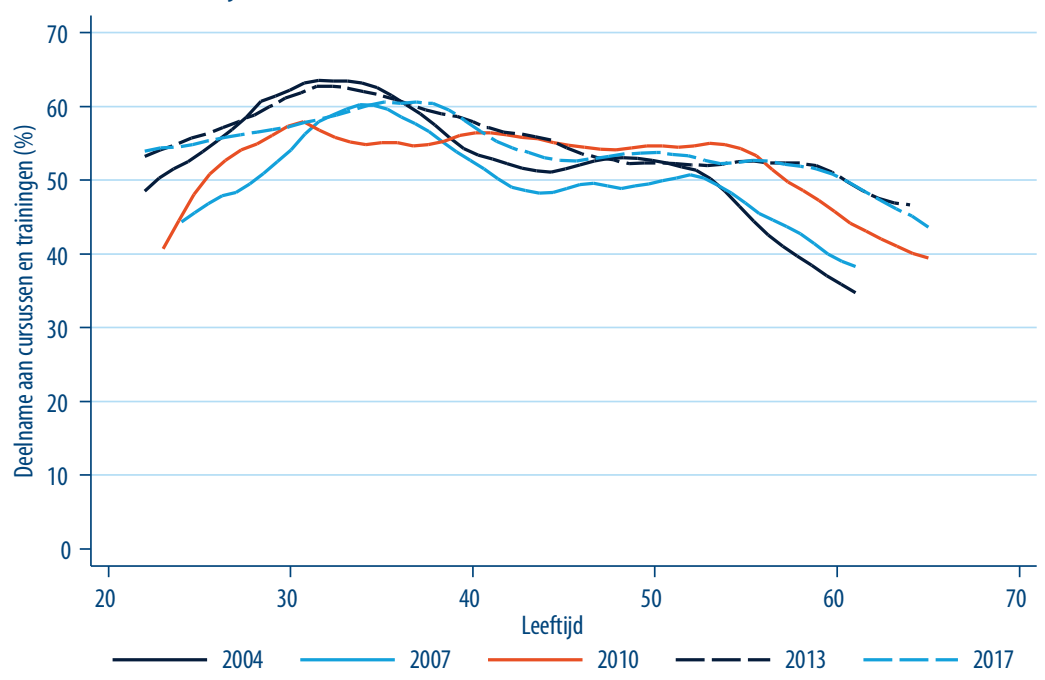

Bron: ROA LLL enquête, 2004-2017

\section{Intensiteit van cursussen}

De intensiteit van cursussen is afgenomen. Hoogopgeleiden volgen langere cursussen dan laag- of middelbaar opgeleiden.
Het gemiddelde aantal door werkenden gevolgde cursussen en trainingen is tussen 2004 en 2017 toegenomen van 2,4 naar 2,9 cursussen. De duur van cursussen daalt in

termen van het aantal dagen, maar stijgt in termen van het aantal uren per cursusdag. Figuur 1.5 laat de ontwikkeling zien van het mediaan aantal cursusdagen en uren per dag dat besteed is aan cursussen. De mediane duur van een cursus nam tussen 2004 en 2017 af van 5 naar 3 dagen. In aantal uren per dag lag de mediane duur van een cursus of training juist hoger in 2017: in 2004 was dat 5 uur per dag tegenover 7 uur per dag in 2017. Als we het gemiddelde aantal cursusdagen en -uren per dag met elkaar combineren, dan kunnen we concluderen dat een gemiddelde cursus minder intensief is geworden: de intensiteit is tussen 2004 en 2017 afgenomen van 25 uur per cursus naar 21 uur per cursus. De daling in de cursusintensiteit heeft zich overigens vrijwel alleen voorgedaan bij de hoogopgeleiden. Hoewel de cursusintensiteit in 2017 nog steeds het hoogst is onder de hoogopgeleiden, daalde deze van gemiddeld 30 uur in 2004 naar nog maar 24 uur in 2017. Voor laag- en middelbaar opgeleiden was de duur van een gemiddelde cursus in 2017 ongeveer even hoog als in 2004, ongeveer 21 uur. 
FIGUUR 1.5 Cursusdeelname van werkenden: mediaan aantal dagen en aantal uren per dag 20042017

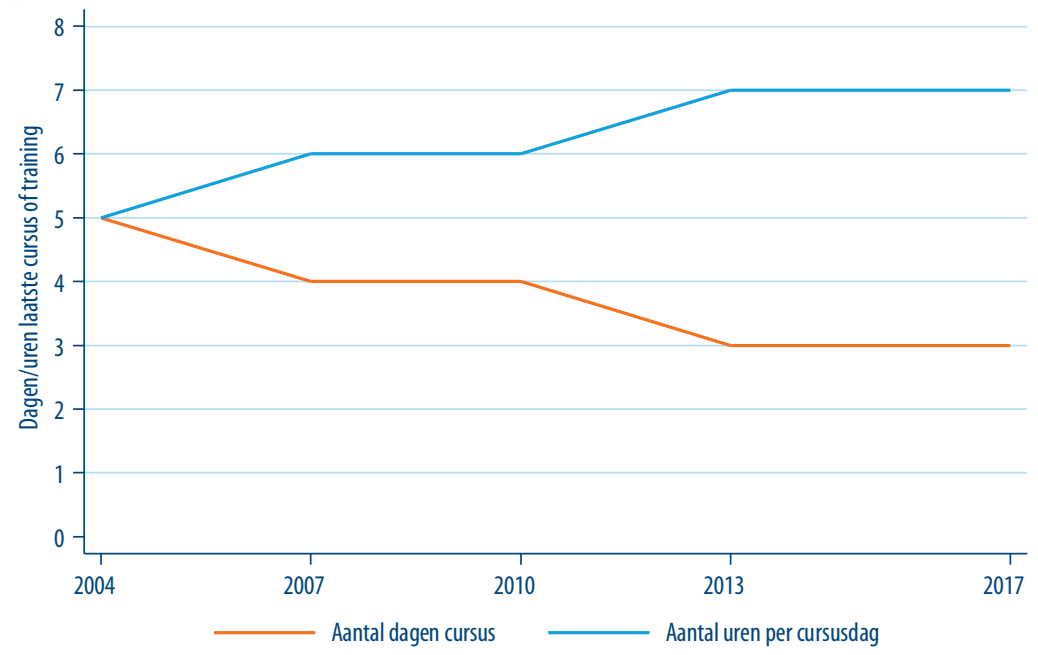

Bron: ROA LLL enquête, 2004-2017

In beleidsdiscussie speelt de vraag in welke mate cursussen bedoeld zijn voor bij-, omen opscholing. Bovenstaande cijfers over het deelnemen aan cursussen, de duur van cursussen en het wel/niet halen van een diploma of certificaat kunnen in dit verband interessante inzichten geven (zie ook Fouarge, 2018). In onderstaand schema vatten wij de informatie samen. Van alle werkenden heeft in 201728 procent nooit een cursus gevolgd. Een groep van 18 procent heeft wel eens een cursus gevolgd, maar niet in de afgelopen twee jaar. Van de werkenden die een cursus hebben gevolgd in de afgelopen twee jaar (54\%) heeft ruim driekwart (76\%) een cursus gevolgd dat minder dan een volle werkweek heeft geduurd. En driekwart van hen heeft de cursus met een diploma of certificaat afgesloten. 24 procent van de werkenden die in de afgelopen twee jaar een cursus heeft gevolgd, heeft een lange cursus gevolgd dat langer dan een volle werkweek duurde. Dergelijke cursussen worden vaker afgesloten met een diploma (90\%). Werkenden die nooit een cursus hebben gevolgd zijn het meest bezorgd over hun employability: 47 procent acht het niet waarschijnlijk dat ze een baan van vergelijkbaar niveau zouden vinden, als ze daar nu naar op zoek zouden gaan. Onder werkenden die in de afgelopen twee jaar een cursus hebben gevolgd is dat slechts 36 procent, waarbij het niet uitmaakt of zij een korte of lange cursus volgden. In hoofdstuk 3 komen wij terug op de relatie tussen cursusdeelname en het gevoel van employability. 


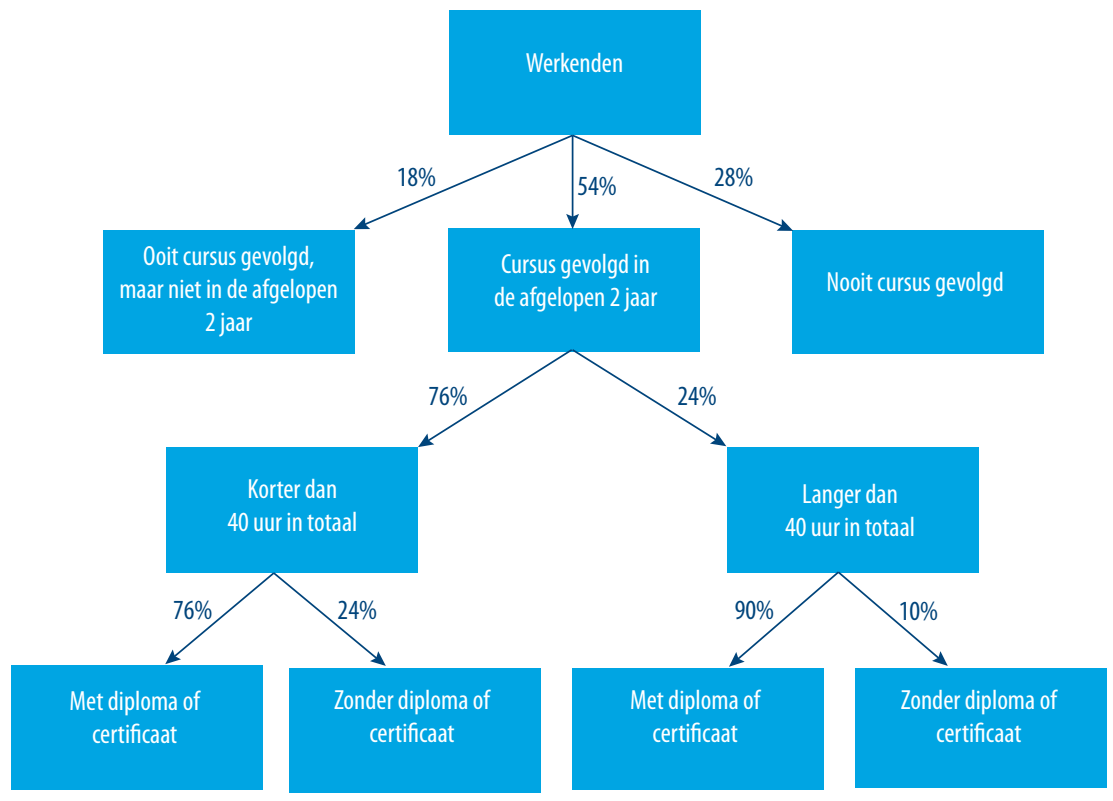

\section{Motieven voor volgen van scholing}

Er zijn verschillende redenen om aan scholing deel te nemen, zoals ook te zien is in Tabel 1.1. In deze tabel worden voor verschillende redenen om een cursus of training te volgen de percentages weergegeven van de werkenden in loondienst. Hieruit blijkt dat de voornaamste reden om een cursus te volgen was dat het ging om een verplichte cursus (41\%); vooral voor laagopgeleiden waarvan meer dan de helft aangaf een verplichte cursus te hebben gevolgd. Dit duidt erop dat werkenden, en in het bijzonder laagopgeleiden, niet altijd zelf de keuze hebben om scholing te volgen. Naast het verplicht zijn om een cursus te volgen worden ook het realiseren van loopbaandoelen en het onvoldoende zijn van de kennis en vaardigheden vaak als reden voor het volgen van een cursus genoemd. ${ }^{5}$ Ook deze redenen worden vaker door laagopgeleiden genoemd dan door middelbaar en hoogopgeleiden. Een hoger inkomen en waardering van de leidinggevende krijgen zijn de minst genoemde redenen om een cursus of training te volgen. De motieven voor het volgen van een cursus of training zijn in 2017 nagenoeg hetzelfde als in 2013: op een enkele uitzondering na zijn de percentages en volgorde gelijk.

5 Aan 80 procent van de respondenten is gevraagd in welke mate zij het eens zijn met de stelling "de cursus/ training ben ik gaan doen omdat mijn kennis en ervaring onvoldoende waren voor het werk dat ik heb". 29 procent is het hier mee eens (zie Tabel 1.1. Aan de overige 20 procent is gevraagd aan te geven in welke mate zij het eens zijn met de stelling "de cursus/training ben ik gaan doen om mijn kennis en ervaring te verbeteren". Een beduidend groter percentage ( $80 \%)$ is het hier mee eens. Dit duidt er op dat cursussen vaak betrekking hebben op het bijspijkeren van kennis. 
TABEL 1.1 Redenen voor het volgen van cursus, werkenden in loondienst naar opleidingsniveau, 2017)

\begin{tabular}{|l|l|l|l|l|}
\hline & $\begin{array}{l}\text { Totaal } \\
\%\end{array}$ & $\begin{array}{l}\text { Laag } \\
\%\end{array}$ & $\begin{array}{l}\text { Middelbaar } \\
\%\end{array}$ & $\begin{array}{l}\text { Hoog } \\
\%\end{array}$ \\
\hline Cursus verplicht & 41 & 51 & 46 & 33 \\
\hline Realiseren loopbaandoelen & 36 & 40 & 33 & 37 \\
\hline Kennis/ervaring onvoldoende & 29 & 35 & 30 & 26 \\
\hline Nieuwe manier van werken & 25 & 26 & 25 & 24 \\
\hline Nieuwe taken gekregen & 24 & 26 & 24 & 23 \\
\hline Kans op andere baan vergroten & 23 & 23 & 23 & 23 \\
\hline Promotie kunnen maken & 16 & 19 & 17 & 15 \\
\hline Als waardering voor goed functioneren & 15 & 23 & 15 & 12 \\
\hline Hoger inkomen & 13 & 14 & 15 & 10 \\
\hline Waardering krijgen van leidinggevende & 10 & 10 & 12 & 9 \\
\hline Bron: ROA LLL enquete, 2017 & & & 15 \\
\hline
\end{tabular}

Bron: ROA LLL enquête, 2017

1) Respondenten mochten meerdere antwoorden aanvinken

\section{Initiatief tot scholing}

Hoogopgeleiden nemen vaker zelf het initiatief tot scholing; voor lager opgeleiden komt het initiatief juist vaker van de werkgever.
Ondanks het feit dat het verplichte karakter van de cursus vaak als reden voor het volgen van scholing wordt opgegeven, lag het initiatief in 2017 vaker bij de respondent zelf dan bij de werkgever. Het is echter wel zo dat door de werkgever geïnitieerde cursussen vaker een verplicht karakter hebben. Van de werkenden gaf 37 procent aan dat zij zelf het initiatief hadden genomen voor het volgen van de cursus, terwijl bij 35 procent de werkgever de initiatiefnemer was en het volgen van de cursus bij 26 procent van de werkenden het gezamenlijke initiatief was van werknemer en werkgever. Naar opleidingsniveau zijn er twee belangrijke verschillen. Bij de hoogopgeleiden ligt het initiatief vaker bij de werknemer, terwijl bij laagopgeleiden vaker de werkgever het initiatief tot scholing neemt. Gecombineerd met de hogere cursusdeelname onder hoogopgeleiden kan dit er op duiden dat hoogopgeleiden een andere houding hebben tegenover het volgen van cursussen. Laagopgeleiden volgen minder cursussen en nemen minder vaak zelf initiatief, wat kan betekenen dat ze het volgen van een cursus eerder als een last zien (Fouarge et al., 2013; Künn-Nelen et al., 2018).

Zowel de directe als indirecte kosten van de cursus of training komen vaak voor rekening van de werkgever.
In 2017 wordt het merendeel van de cursussen betaald door de werkgever ( $84 \%)$. Dit is een kleine daling ten opzichte van 2013 (87\%). Deze daling is vooral toe te schrijven aan de laag- en middelbaar opgeleiden die de kosten iets vaker zelf moeten betalen. Een cursus die de werknemer zelf betaald is overigens vaker relevant voor de externe arbeidsmark dan voor de huidige baan. Dit is in lijn met wat de menselijk kapitaal theorie voorspelt: 
naarmate cursussen meer generiek zijn, wordt verwacht dat de werknemer de kosten draagt (Becker, 1964).

De helft van de cursussen wordt tijdens werktijd gevolgd. Dit betekent dat naast de directe kosten ook de indirecte kosten vaak door de werkgever worden betaald. 27 procent van de cursussen wordt geheel in eigen tijd gevolgd. De overige 23 procent van de cursussen vindt gedeeltelijk in eigen tijd en gedeeltelijk tijdens werktijd plaats. ${ }^{6}$

\section{Transfer van kennis}

70 procent van de werkenden kan de opgedane kennis goed in praktijk brengen. Bovendien profiteren bij 46 procent van de gevolgde cursussen ook de collega's die zelf de cursus niet hebben gevolgd door kennisoverdracht op de werkvloer.
Van de werkenden heeft ongeveer 70 procent de door de cursus verworven kennis op het werk kunnen toepassen.? Dit betekent echter ook dat bij 30 procent van de werkenden die een cursus heeft gevolgd, deze cursus geen direct impact heeft gehad op het werk.

Uit de literatuur blijkt dat er sprake kan zijn van spillover effecten van scholing: wat men leert op een cursus heeft ook positieve effecten voor andere medewerkers waarmee men samenwerkt (de Grip \& Sauermann, 2012). Volgens 46 procent van de werkenden lukte het om de opgedane kennis over te dragen aan hun collega's, waarbij opgemerkt moet worden dat laagopgeleiden hier minder goed in slagen dan middelbaar en hoogopgeleid. Hierdoor heeft een groter deel van de werkenden in een bedrijf profijt van de gevolgde cursussen dan alleen degenen die de cursus zelf hebben gevolgd. Ook werkt het volgen van een cursus of training voor een aantal werkenden als een stimulans: ongeveer 39 procent van de werkenden geeft aan dat de gevolgde cursus of training het leren tijdens het werk heeft gestimuleerd. Dit duidt er op dat het formeel leren het informeel leren op het werk vergroot. In paragraaf 1.2 komen we daarop terug.

\subsection{Ontwikkelingen in informeel leren op het werk}

Het informeel leren op het werk is afgenomen van 31 procent in 2010 naar 24 procent in 2017.

totale leertijd, zoals we later in dit hoofdstuk zullen laten zien. Informeel leren kan tijdens verschillende activiteiten plaatsvinden. Tijdens het werk, bijvoorbeeld bij het uitvoeren van nieuwe of uitdagende taken, maar ook buiten het werk, bijvoorbeeld tijdens het doen van vrijwilligerswerk. Het leren op het werk wordt in deze paragraaf behandeld en in paragraaf 1.3 komt het leren buiten het werk aan bod.

6 Hoogopgeleide werkenden volgen vaker dan laagopgeleiden cursussen gedeeltelijk in eigen tijd en gedeeltelijk tijdens werktijd.

7 Dit percentage verschilt niet naar opleidingsniveau. 
Voor het meten van het informeel leren op het werk zijn respondenten in de ROA Levenslang Leren Enquête gevraagd hoeveel procent zij van hun werktijd besteden aan taken waarvan zij kunnen leren. ${ }^{8}$ De eerste metingen 2004, 2007 en 2010 laten een lichte afname (maar significante) zien van 31 naar 28 procent van de werktijd besteed aan activiteiten waarvan men kan leren (Figuur 1.6). Dit percentage maakte een sterke stijging door in 2013 naar 35 procent waarna het informele leren op het werk in 2017 weer sterk afnam tot onder het niveau van 2010: 24 procent. Hiermee lijkt 2013 een uitzondering te zijn op een dalende trend in het informeel leren op het werk die in 2017 weer wordt voortgezet. ${ }^{9}$ Een verklaring vinden voor deze dalende trend is lastig, maar misschien dat de drang om werkprocessen te optimaliseren met het oog op het bereiken van een grotere efficiency hier een verklaring voor biedt. Dit verdient echter nader onderzoek.

FIGUUR 1.6 Informeel leren op het werk: ontwikkeling van het percentage van de werktijd besteed aan activiteiten waarvan men kan leren, 2004-2017

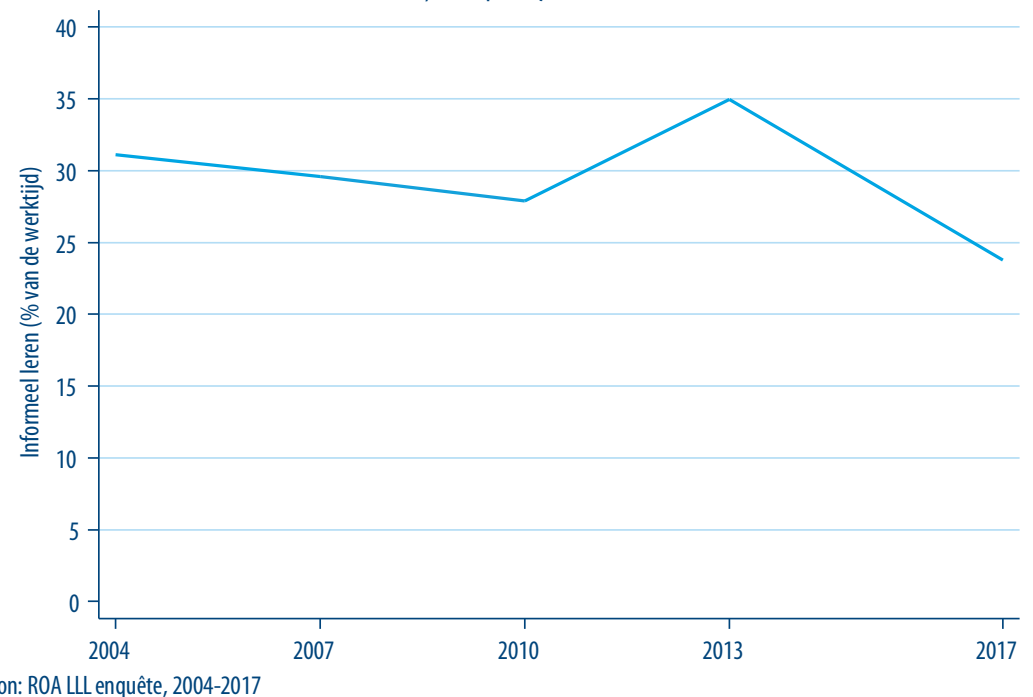

Bron: ROA LLL enquête, 2004-2017

Slechts 15 procent van de totale leertijd op het werk heeft betrekking op het leren van cursussen. die iemand op het werk leert gemiddeld 85 procent betrekking heeft op het leren van de taken die men uitvoert. ${ }^{10}$ Slechts 15 procent heeft betrekking op de tijd die besteed is aan cursussen en trainingen.

8 Zie voor een verantwoording van de meting van informeel leren: Borghans et al. (2007).

92013 laat een ander beeld zien van het niveau van het informeel leren van taken op het werk dan andere jaren. Het is echter niet goed te achterhalen wat hier speelt, maar verschillen in de bewoording van de enquêtevragen spelen geen rol (zie bijlage $A$ ).

10 In bijlage B wordt de berekening achter Figuur 1.7 nader toegelicht. 
Dit duidt erop dat het informele leren op het werk veel belangrijker is dan het formele leren. In een eerder rapport gaven wij aan dat men vooral leert van nieuwe en uitdagende werkzaamheden en relatief weinig van routine werkzaamheden en vergaderen en overleg (Borghans et al., 2011).

FIGUUR 1.7 Totale leertijd op het werk onderverdeeld voor een gemiddeld persoon, 2017

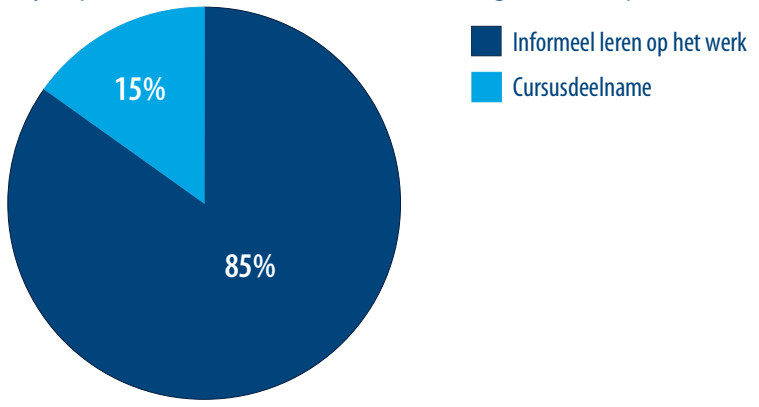

Bron: ROA LLL enquête, 2004-2017

In Figuur 1.8 wordt het informele leren op het werk gedifferentieerd naar opleidingsniveau. Tijdens het werk besteden hoogopgeleiden, vergeleken met middelbaar- en laagopgeleiden, meer tijd aan activiteiten waarvan men kan leren. Tussen middelbaaren laagopgeleiden zit met uitzondering van 2013 weinig verschil in het informele leren op het werk. In 2013 was de toename van het informele leren op het werk vooral het gevolg van een sterke stijging onder de middelbaar opgeleiden. Het informele leren van laagopgeleiden bleef echter gelijk, waardoor er een kloof tussen middelbaar- en laagopgeleiden ontstond. In 2017 is deze kloof echter weer verkleind door een daling van het informele leren op het werk onder de middelbaar opgeleiden, van 35 naar 22 procent van de totale werktijd. 
FIGUUR 1.8 Informeel leren op het werk: ontwikkeling van het percentage van de werktijd besteed aan activiteiten waarvan men kan leren naar opleidingsniveau 2004-2017

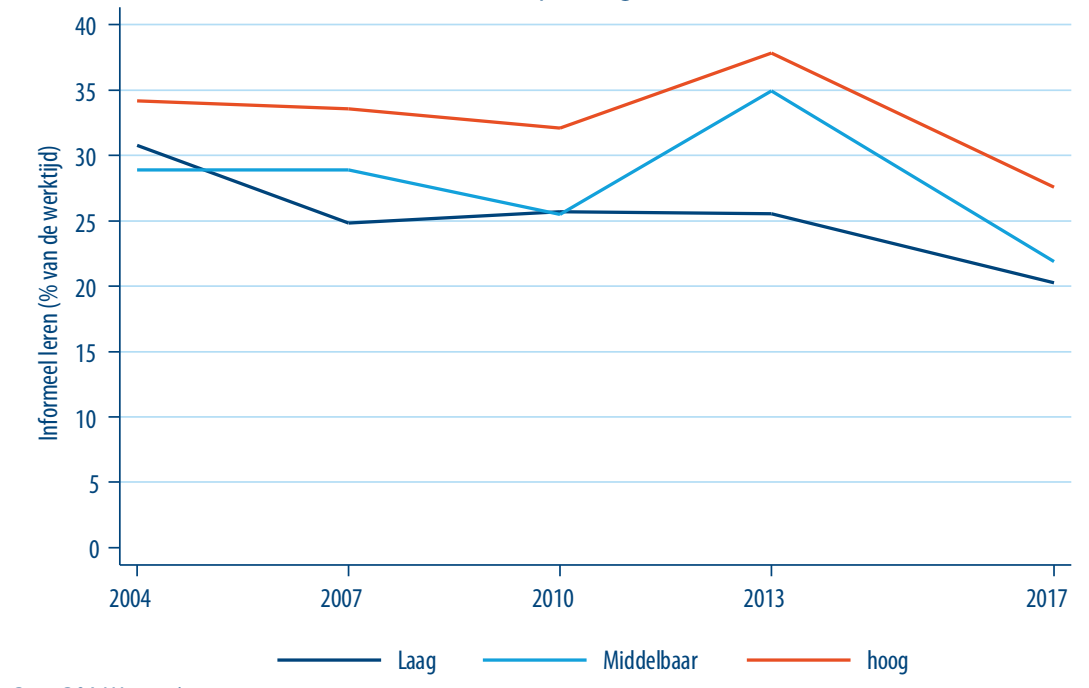

Bron: ROA LLL enquête, 2004-2017

Arbeidsmobiliteit gaat gepaard met meer informeel leren op het werk.
Uit Figuur 1.9 blijkt dat jongeren over het algemeen het vaakst informeel leren op het werk. In alle metingen is er een daling te zien in het informele leren op het werk naarmate de leeftijd van de respondenten toeneemt. De algemene daling van het informele leren op het werk tussen 2004 en 2017 komt ook hier weer duidelijk naar voren: Voor alle leeftijdsgroepen ligt de lijn van 2017 onder die van de andere jaren. De meting van 2013 steekt er daarentegen voor alle leeftijdsgroepen bovenuit.

Dat jongeren vaker informeel leren op het werk is logisch omdat men dan vaak net de arbeidsmarkt op komt en veel taken nog betrekkelijk nieuw zijn. Uit nadere analyses waarin gecontroleerd wordt voor iemands opleidingsniveau, geslacht en leeftijd blijkt dat tien jaar langer in dienst zijn gepaard gaat met een 12 procentpunt lager niveau van informeel leren op het werk. Tevens blijkt dat na correctie voor opleidingsniveau, geslacht en leeftijd het informele leren ongeveer 5 procentpunten hoger ligt onder werknemers die in de afgelopen twee jaar van werkgever zijn veranderd, of bij hun werkgever van functie zijn veranderd. Dit suggereert dat men inderdaad veel leert van nieuwe taken. 
FIGUUR 1.9 Informeel leren op het werk: ontwikkeling van het percentage van de werktijd besteed aan activiteiten waarvan men kan leren naar leeftijd, 2004-2017

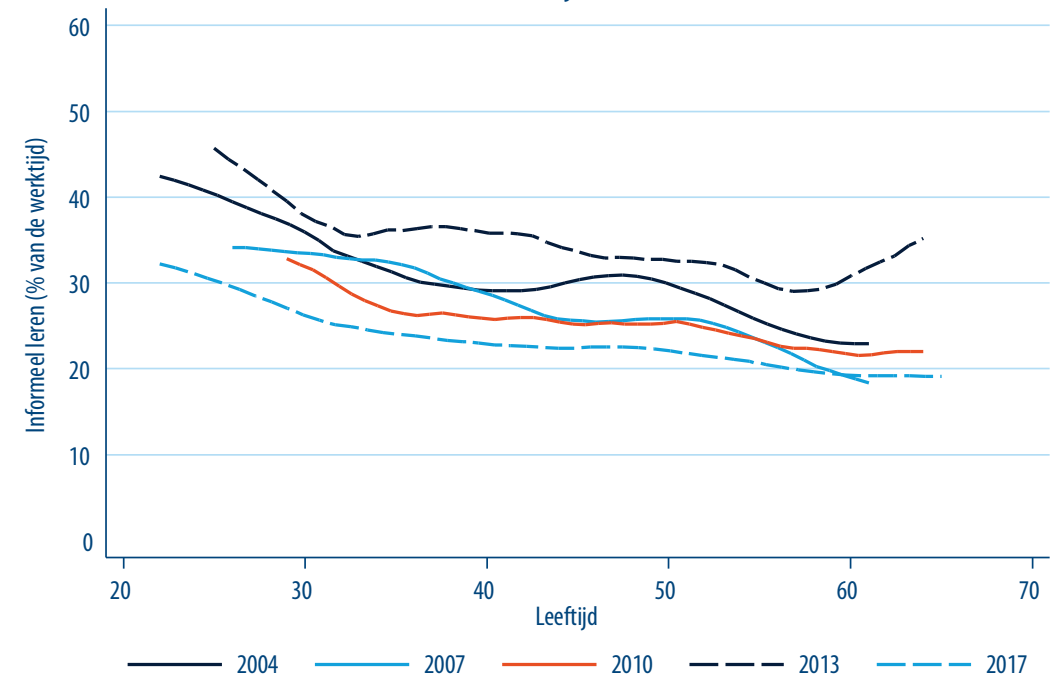

Bron: ROA LLL enquête, 2004-2017

De sectoren met het hoogste percentage informeel leren van de taken op het werk zijn het onderwijs en de financiële instellingen en zakelijke dienstverlening.
Hoe leerzaam iemands werkzaamheden zijn, kan tussen beroepen en sectoren variëren. Hoewel Figuur 1.10 laat zien dat er in een groot aantal sectoren gemiddeld genomen rond de 20 procent van de werktijd besteed wordt aan taken waarvan men leert, er ook sectoren zijn waarbinnen het informeel leren op het werk aanmerkelijk hoger ligt. Dit geldt vooral in het onderwijs en bij de financiële instellingen en zakelijke dienstverlening. In deze sectoren wordt bijna 30 procent van de werktijd besteed aan taken waarvan men leert. Dit zijn ook de sectoren waarin werkenden zowel in 2010 als in 2013 relatief weinig tijd besteden aan routine werkzaamheden. ${ }^{11}$

11 Informatie hierover is niet beschikbaar in 2017. 
FIGUUR 1.10 Informeel leren op het werk: het percentage van de werktijd besteed aan activiteiten waarvan men kan leren naar sector, 2017

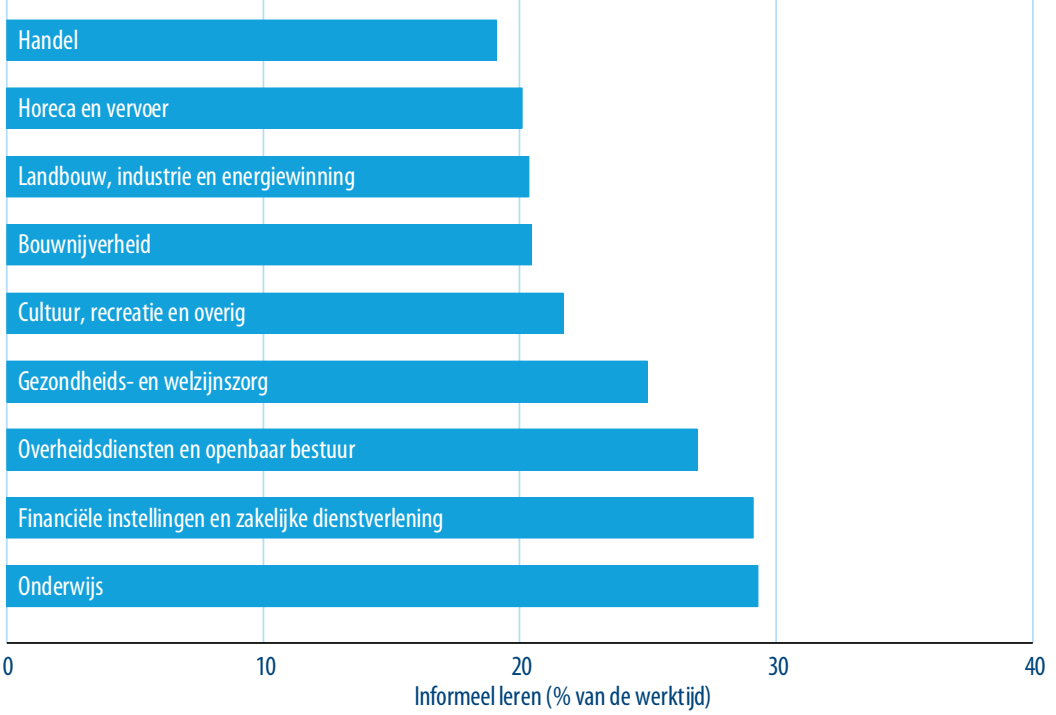

Bron: ROA LLL enquête, 2004-2017

In grote bedrijven ligt de cursusdeelname hoger dan in kleine bedrijven. Het informeel leren van taken op het werk is echter onafhankelijk van de grootte van het bedrijf.

cieren dan kleine bedrijven. Dat werkenden in grote bedrijven vaker cursussen volgen komt dan ook duidelijk naar voren in Figuur 1.11. Daar staat tegenover dat het informeel leren van taken op het werk onafhankelijk is van de bedrijfsgrootten. 
FIGUUR 1.11 Formeel en informeel leren uitgesplitst naar bedrijfsgrootte, 2017

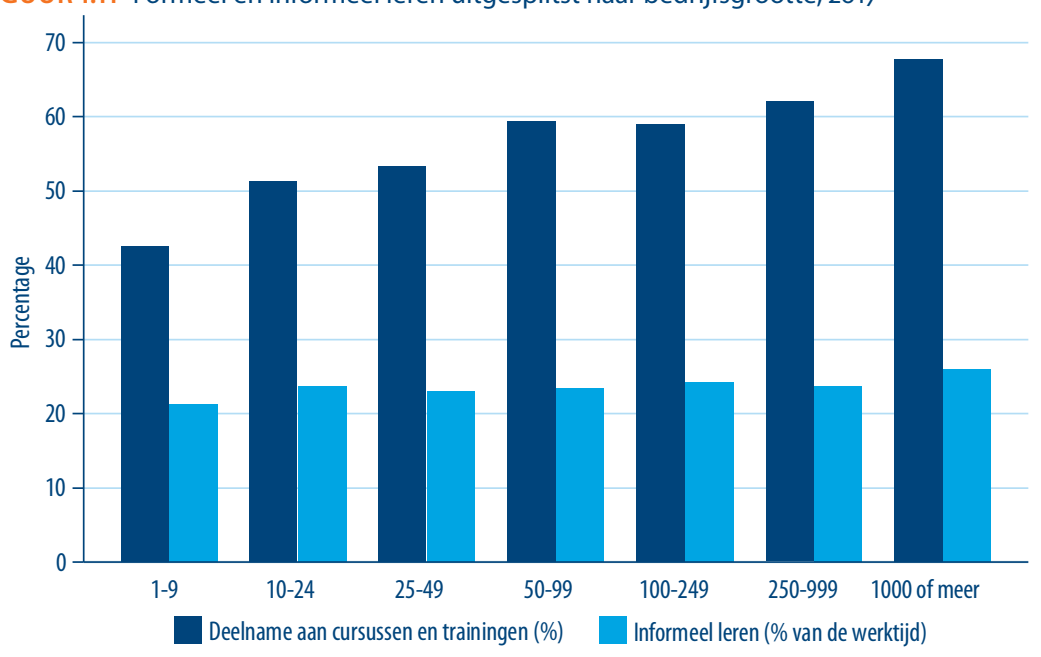

Bron: ROA LLL enquête, 2004-2017

\section{Leerrendement van informeel leren}

Werkenden leren per uur meer van de taken op hun werk dan van cursussen.
Het informele leren op het werk heeft een groter aandeel in de totale leertijd op het werk dan het volgen van cursussen en trai-

ning. Maar halen werkenden ook meer rendement uit de tijd die ze besteden aan taken waarvan ze kunnen leren? Om deze vraag te kunnen beantwoorden wordt in de ROA Levenslang Leren Enquête 2017 gevraagd waar iemand meer van leert, een cursus van 8 uur of 8 uur informeel leren op het werk. ${ }^{22}$ Hieruit blijkt dat werkenden gemiddeld genomen aangeven dat ze net zoveel leren van een uur informeel leren op het werk dan van een uur formeel leren. Hiermee wordt het belang van het informele leren op het werk nog eens onderstreept: men besteedt er tijdens het werk veel meer tijd aan en het rendement ligt gelijk aan dat van het volgen van een cursus. Dit betekent dat men over het geheel genomen veel meer leert van de taken die men doet dan van de cursussen die men volgt. ${ }^{13}$ gevolgd. De vergelijking betrof 4 of 8 uren cursus en leren op het werk waarbij de waarden 4 en 8 waren gerandomiseerd. Er zijn geen significante verschillen in de antwoorden als de vergelijking op 4 of 8 uur betrekking heeft.

13 Een kanttekening hierbij is dat niet alle vaardigheden informeel geleerd kunnen worden. Voor rekenen, bijvoorbeeld, geldt dat men dit vooral geleerd heeft in een formele setting (ter Weel \& Kok, 2013). Bovendien geldt dat in multivariate analyses waarin gecontroleerde wordt voor geslacht, opleiding en leeftijd, werkenden significant positiever zijn over het rendement van cursussen naarmate zij zelf meer cursussen hebben gevolgd en significant positiever zijn over het rendement van informeel leren naarmate zij zelf meer informeel leren van hun taken. 


\subsection{Leren buiten het werk}

In de ROA Levenslang Leren Enquête wordt naast formeel leren en informeel leren op het werk ook gemeten of, en in welke mate, men van andere activiteiten buiten het werk leert. Hierbij gaat het om zelfstudie en het leren van activiteiten als vrijwilligerswerk, mantelzorg en de tijd die men besteedt aan kinderen. In deze paragraaf wordt beschreven in welke mate werkenden en niet-werkenden deelnemen aan dergelijke activiteiten, en in welke mate zij aangeven hiervan iets te kunnen leren.

\section{Zelfstudie}

Zelfstudie omvat de tijd die men thuis besteedt aan zelfstandig leren of kennis bijhouden door middel van het lezen van handboeken of (vak)literatuur zonder dat dit gerelateerd is aan een cursus die men volgt. ${ }^{14}$ De tijd besteed aan zelfstudie is in de laatste twee peilingen van de ROA Levenslang Leren Enquête (2013 en 2017) aan de respondenten gevraagd.

48 procent van de werkenden doet thuis aan zelfstudie, gemiddeld 3 uur per maand.
Werkenden besteden in 2017 vaker thuis tijd aan zelfstudie dan in 2013. De deelname aan zelfstudie onder werkenden lag in 2017 op 48 procent van de werkenden, tegenover 41 procent in 2013. Gemiddeld zijn ze hier 3 uur per maand mee bezig. Van de niet-werkenden (exclusief studenten) doet 26 procent aan zelfstudie, en zij besteden daar eveneens gemiddeld 3 uur per maand aan. Hoogopgeleide werkenden doen vaker aan zelfstudie (64\%) dan middelbaar (40\%) en laagopgeleiden (33\%) en besteden er ook meer tijd aan, 4 uur per maand tegenover 2 uur per maand bij de middelbaar en laagopgeleiden.

\section{Informeel leren buiten het werk}

In de ROA Levenslang Leren Enquête 2017 is voor het eerst een poging gedaan om een inschatting te geven van de mate waarin men leert van activiteiten buiten het werk. Hierbij is er voor gekozen om de focus te leggen op een drietal vaak voorkomende activiteiten: 1) het verlenen van mantelzorg, 2) het deelnemen aan vrijwilligerswerk, en 3) het besteden van tijd aan kinderen. Eerst is aan de respondenten gevraagd of zij tijd besteden aan deze activiteiten. Zo ja, dan worden ze gevraagd hoeveel uren per week en hoeveel procent van deze tijd besteed is aan activiteiten waarvan men kan leren. Leerzame taken bij mantelzorg zouden te maken kunnen hebben met het feit dat men zich moet verdiepen in verschillende regelingen, afspraken moet maken met zorginstellingen, of beter leert communiceren. Bij vrijwilligerswerk kan bijvoorbeeld worden geleerd van het leiding geven aan een sportteam of het organiseren van de boekhouding van de vereniging. Tijd met kinderen kan leerzaam zijn omdat men bijvoorbeeld

14 In de vraagstelling is gerandomiseerd naar de periode waarin zelfstudie gerapporteerd moest worden: in de afgelopen 12 maanden, 6 maanden of 1 maand. Werkenden die moesten rapporteren over zelfstudie in de afgelopen maand rapporteren significant minder vaak aan zelfstudie. Dit suggereert dat zelfstudie een activiteit is die men met een lage intensiteit uitvoert 
tijd besteedt aan de begeleiding van huiswerk. Meer in het algemeen zouden deze activiteiten tot reflectie kunnen leiden en een betere zelfkennis.

Figuur 1.12 laat zien in hoeverre werkenden en niet-werkenden deelnemen aan deze leeractiviteiten buiten het werk. Werkenden besteden 2 procentpunten vaker tijd aan kinderen dan niet-werkenden. ${ }^{15}$ Niet-werkenden geven vaker aan dan werkenden dat zij tijd besteden aan mantelzorg en vrijwilligerswerk.

Mogelijk speelt hier ook de beschikbare vrije tijd van niet-werkenden een rol. In eerder onderzoek is aangetoond dat meer uren werk niet allen ten kosten gaat van minder vrije tijd, maar ook ten kosten gaat van de tijd die men besteed aan mantelzorg en vrijwilligerswerk (Dekker et al., 2008).

FIGUUR 1.12 Informeel leren buiten het werk: deelname aan activiteiten buiten het werk, in procenten, waarvan men kan leren, 2017

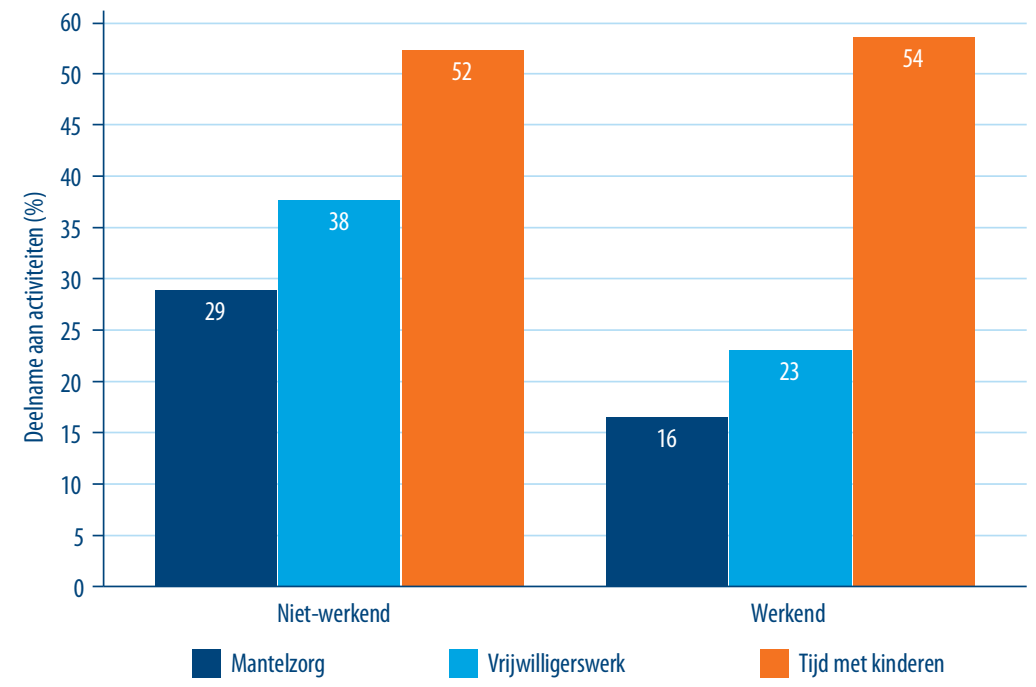

Bron: ROA LLL enquête, 2004-2017

Niet-werkenden besteden procentueel meer tijd aan informeel leren buiten het werk dan werkenden.

vergelijkbare vraagstelling gebruikt als voor het meten van informele leren op het
Vervolgens laat Figuur 1.13 zien in hoeverre men ook daadwerkelijk leert van de bovengenoemde activiteiten. Voor het meten van deze vorm van informeel leren wordt een

15 De vraag is gesteld aan mensen ongeacht of zij (thuiswonende) kinderen hebben. Onder de werkenden, zijn er 364 personen die aangeven dat zij tijd besteden aan kinderen maar zelf geen thuiswonende kinderen hebben. Daarvan heeft 298 ooit een kind gehad. Het kan dus zijn dat zij rapporteren over tijd besteed aan niet thuiswonende kinderen of kleinkinderen. De tijd waarvan men leert van kinderen is niet significant verschillend tussen de groep die thuiswonende kinderen heeft en de groep die dat niet heeft. 
werk..$^{16}$ Opmerkelijk is dat niet-werkenden van alle drie activiteiten meer leren dan werkenden. Dat is vooral het geval bij het informele leren van vrijwilligerswerk waar niet-werkenden 8 procentpunten meer van leren. De leerzaamste activiteit onder werkenden is de tijd met kinderen, voor niet-werkenden is dat het vrijwilligerswerk dat ze doen.

Laagopgeleide werkenden leren meer van mantelzorg dan middelbaar- en hoogopgeleiden. Hoogopgeleiden leren daarentegen het meest van de tijd die ze besteden aan vrijwilligerswerk en aan kinderen. Onder de niet-werkenden zijn het ook de hoogopgeleiden die het meeste leren van de tijd die ze besteden aan vrijwilligerswerk. Van mantelzorg en de tijd met kinderen leren laag opgeleiden ongeveer evenveel als hoogopgeleiden. Middelbaar opgeleiden leren van deze activiteiten het minst.

FIGUUR 1.13 Inforel leren buiten het werk: percentage van de totale tijd besteed aan activiteiten waarvan kan leren, 2017

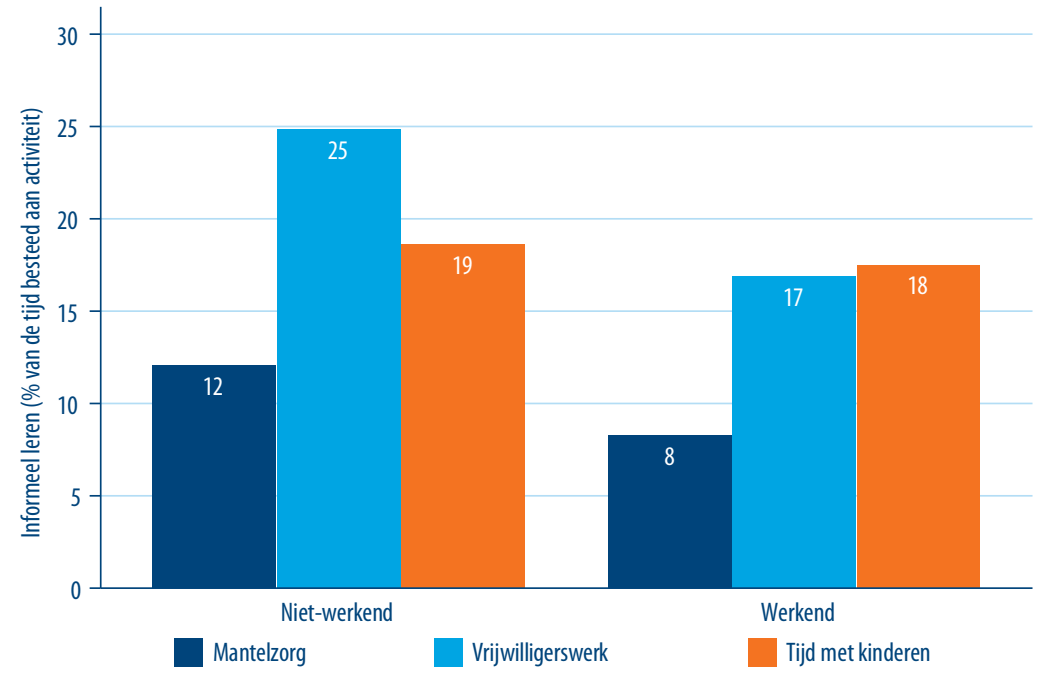

Bron: ROA LLL enquête, 2004-2017

16 Voor vrijwilligerswerk gaat dit bijvoorbeeld als volgt: "Eerder hebt $u$ aangegeven dat $u$ tijd besteedt aan vrijwilligerswerk. Hoeveel procent van deze tijd besteedt u aan taken waarvan u kunt leren?" De antwoordmogelijkheden gaan van o tot 100 procent. 


\section{Leertijd verdeeld naar activiteiten}

Figuur 1.6 gaf een beeld van de verdeling van de leertijd op het werk (cursussen en leren van taken). Figuur 1.14 breidt dit uit met het leren van de activiteiten buiten het werk. ${ }^{7}$ Het gaat hier om de gemiddelde leertijd van werkenden. Vanzelfsprekend kan de samenstelling van deze leertijd sterk verschillen tussen personen, omdat niet iedereen deelneemt aan alle activiteiten.

FIGUUR 1.14 Totale leertijd van werkenden, onderverdeeld voor een gemiddeld persoon, 2017

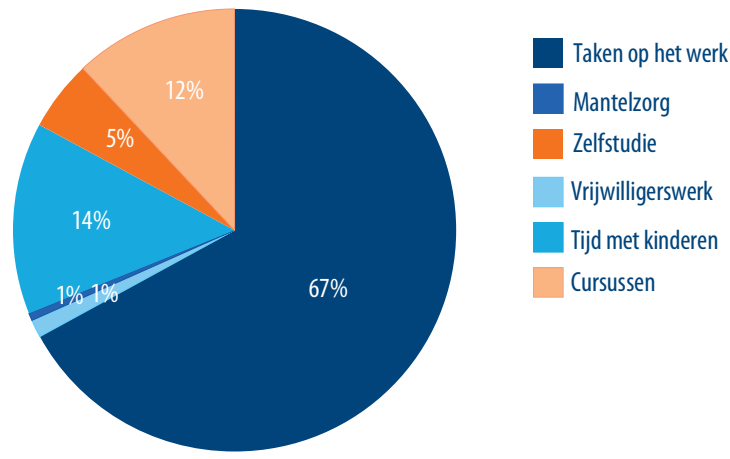

Bron: ROA LLL enquête, 2004-2017

Uit Figuur 1.14 blijkt dat ook als de leeractiviteiten buiten het werk worden meegenomen het informeel leren van de taken op het werk nog steeds het overgrote deel van de totale leertijd uitmaakt (67\%). Andere belangrijke leeractiviteiten zijn de cursussen die men volgt en tijd met kinderen, die respectievelijk 12 procent en 14 procent van de totale leertijd in beslag nemen. Het aandeel van zelfstudie ligt met 5 procent van de totale leertijd lager. Ten slotte zien we dat zowel vrijwilligerswerk als mantelzorg slechts 1 procent van de totale leertijd in beslag nemen.

Als het leren van taken op het werk buiten beschouwing wordt gelaten leren zowel werkenden als niet-werkenden het meeste van tijd met kinderen. Niet-werkenden leren echter aanzienlijk meer van vrijwilligerswerk en mantelzorg waar werkenden juist meer leren van cursussen.
De verdeling van de totale leertijd ziet er uiteraard anders uit voor de niet-werkenden, met als belangrijkste reden dat nietwerkenden per definitie niet kunnen leren van taken op het werk. Om toch een vergelijking te kunnen maken tussen het leergedrag van werkenden en niet-werkenden geeft Figuur 1.15 de verdelingen van de leertijd weer, waarbij wij voor werkenden het informeel leren van taken op het werk niet wordt

17 De berekeningen wordt in bijlage B nader toegelicht. 
meegerekend. ${ }^{18}$ Voor zowel werkenden als niet-werkenden heeft tijd met kinderen het grootste aandeel in de totale leertijd, en dit aandeel verschilt nauwelijks tussen beide groepen (respectievelijk $43 \%$ en $46 \%$ ). Ook het aandeel van de leertijd door zelfstudie is vergelijkbaar tussen beide groepen (aandeel van respectievelijk 16\% en 15\%). De aandelen van de overige drie activiteiten verschillen daarentegen tussen werkenden en niet-werkenden. Voor werkenden ligt het aandeel van cursusdeelname vrij hoog (36\%) waar deze voor niet-werkenden relatief laag ligt (14\%). Vooral de omvang van het aandeel van vrijwilligerswerk in de totale leertijd is opvallend verschillend aangezien deze voor werkenden enkel 4 procent bedraagt en voor niet-werkenden met 18 procent aanzienlijk hoger ligt. Ook het aandeel van mantelzorg in de totale leertijd ligt onder niet-werkenden aanzienlijk hoger dan onder werkenden (7\% tegenover $2 \%)$. De verschillen tussen werkenden en niet-werkenden komen voort uit de verschillen in deelname zoals eerder in dit hoofdstuk al naar voren kwam. Waar het aandeel van cursusdeelname in de totale leertijd onder werkenden aanzienlijk hoger ligt vergeleken met niet-werkenden zagen we in Figuur 1.1 dat werkenden ook vaker deelnemen aan cursussen. Daarbij bleek uit Figuur 1.12 dat niet-werkenden juist vaker deelnemen aan vrijwilligerswerk en mantelzorg wat een hoger aandeel in Figuur 1.15 kan verklaren.

FIGUUR 1.15 Vergelijking totale leertijd werkenden en niet-werkenden, onderverdeeld voor een gemiddeld persoon, 2017
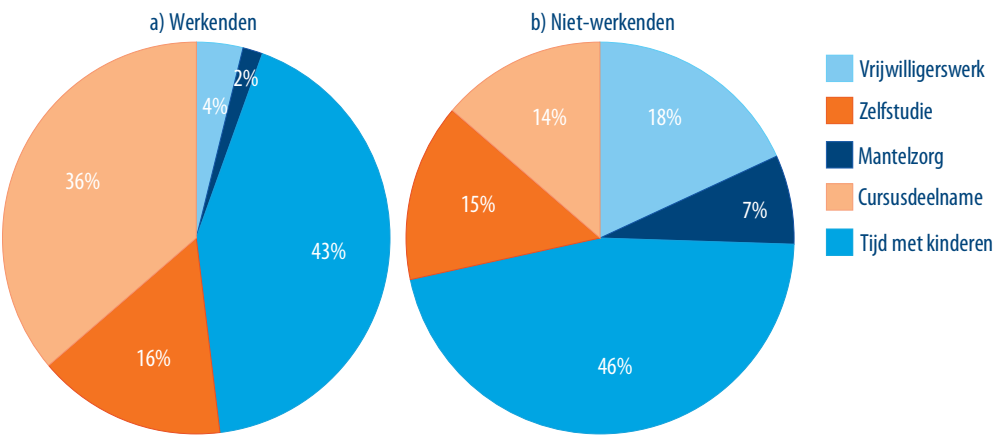

Bron: ROA แL enquête, 2004-2017

\subsection{Bruikbaarheid van formeel en informeel leren voor de loopbaan}

De Figuren 1.12 en 1.13 roepen een tweetal vragen op. Ten eerste, is het informeel leren tijdens vrijwilligerswerk, mantelzorg en de tijd met kinderen, ook werk- of arbeidsmarkt gerelateerd? Het zou immers ook om meer algemene kennis kunnen gaan die niet direct relevant is voor het opbouwen van vaardigheden die productief ingezet kunnen worden op de arbeidsmarkt. Ten tweede is het de vraag waarvoor de tijd besteed aan

18 Zie bijlage B voor de berekening. Aan de hand van stellingen is gevraagd in welke mate ( $1=$ helemaal niet, ..., $5=$ in zeer hoge mate) de opgedane kennis en vaardigheden tijdens de verschillende leeractiviteiten relevant is voor de huidige baan, voor de loopbaan binnen huidige organisatie, in een andere organisatie in dezelfde branche en in een andere organisatie in een andere branche. 
cursussen of informeel leren op het werk relevant is. Zo kunnen de opgedane kennis en vaardigheden uitsluitend relevant zijn voor iemands huidige baan, of juist voor iemands bredere inzetbaarheid op de arbeidsmarkt. Om deze vragen te beantwoorden laat Tabel 1.2 de bruikbaarheid van de leeractiviteiten voor werkenden zien in vier werk gerelateerde situaties: ${ }^{19}$ in de interne organisatie (in de huidige baan of voor de loopbaan binnen huidige organisatie) en in andere organisaties (in een andere organisatie in dezelfde branche of in een andere organisatie in een andere branche). ${ }^{20}$

Uit Tabel 1.2 blijkt dat de bruikbaarheid op de arbeidsmarkt van het informeel leren buiten het werk voor werkenden relatief laag is. ${ }^{21}$ Slechts 25 procent van de werkenden geeft bijvoorbeeld aan dat de tijd besteed aan vrijwilligerswerk bruikbaar was voor de huidige baan, een percentage dat bij de tijd besteed aan cursussen (73\%) of zelfstudie (71\%) aanmerkelijk hoger ligt. Ook voor de loopbaan binnen de huidige organisatie of voor een baan bij een andere organisatie in dezelfde of een andere branche is de bruikbaarheid van de opgedane kennis en vaardigheden het laagst voor het leren van vrijwilligerswerk, mantelzorg en de tijd met kinderen.

TABEL 1.2 Bruikbaarheid van opgedane kennis voor de interne en externe organisatie, 2017)

\begin{tabular}{|c|c|c|c|c|}
\hline \multirow[b]{2}{*}{ Leeractiviteit } & \multicolumn{2}{|c|}{ Bruikbaarheid voor interne organisatie } & \multicolumn{2}{|c|}{ Bruikbaarheid voor externe organisatie } \\
\hline & $\begin{array}{c}\text { Huidige baan } \\
\qquad\end{array}$ & $\begin{array}{l}\text { Loopbaan binnen } \\
\text { huidige organisatie } \\
\%\end{array}$ & $\begin{array}{c}\text { Andere organisatie, } \\
\text { dezelfde branche } \\
\%\end{array}$ & $\begin{array}{c}\text { Andere organisatie, } \\
\text { andere branche } \\
\%\end{array}$ \\
\hline Cursussen & 73 & 59 & 67 & 42 \\
\hline Zelfstudie & 71 & 58 & 61 & 30 \\
\hline Vrijwilligerswerk & 25 & 18 & 22 & 23 \\
\hline Mantelzorg & 20 & 13 & 16 & 15 \\
\hline Tijd met kinderen & 16 & 10 & 11 & 12 \\
\hline Taken op het werk & -2) & 63 & 62 & 32 \\
\hline
\end{tabular}

1) Percentage werkenden dat aangeeft dat de opgedane kennis en vaardigheden tijdens de verschillende leeractiviteiten in hoge of zeer hoge mate bruikbaar was. 2) Het leren van taken op het werk is in principe altijd bruikbaar binnen de huidige baan. Vandaar dat hier niet expliciet naar gevraagd is. Bron: ROA LLL enquête, 2017

Een cursus blijkt voornamelijk bruikbaar te zijn voor iemands huidige baan of een baan bij een andere organisatie binnen dezelfde branche. Toch is $42 \%$ van de in cursussen opgedane kennis ook bruikbaar in een baan in een andere branche. Ook bij het leren van taken op het werk zien we dat de bruikbaarheid voor een baan bij een andere organisatie in een andere branche veel lager ligt dan in een baan bij een andere organisatie

19 Aan de hand van stellingen is gevraagd in welke mate ( $1=$ helemaal niet, $\ldots, 5=$ in zeer hoge mate) de opgedane kennis en vaardigheden tijdens de verschillende leeractiviteiten relevant is voor de huidige baan, voor de loopbaan binnen huidige organisatie, in een andere organisatie in dezelfde branche en in een andere organisatie in een andere branche.

20 De tijd besteed aan leren op het werk is uiteraard relevant voor de huidige baan waardoor de bruikbaarheid voor de huidige baan niet bevraagd is voor informeel leren op het werk.

21 Wanneer informeel leren leidt tot beter zelfkennis of reflectie, kan het lastig zijn voor de respondent om de waarde hiervan voor de arbeidsmarkt goed in te schatten. 
in dezelfde branche. Het leren van taken op het werk blijkt van alle leeractiviteiten het meest bruikbaar te zijn voor de loopbaan binnen de huidige organisatie, al is het verschil met de bruikbaarheid van cursussen en zelfstudie vrij klein.

TABEL 1.3 Percentage niet-werkenden dat aangeeft dat de opgedane kennis en vaardigheden tijdens de verschillende leeractiviteiten in hoge of zeer hoge mate bruikbaar is in een volgende baan, 2017

\begin{tabular}{|l|c|} 
& Bruikbaarheid in een volgende baan \\
\hline Leeractiviteit & $\%$ \\
\hline Cursussen & 48 \\
\hline Zelfstudie & 32 \\
\hline Vrijwilligerswerk & 28 \\
\hline Mantelzorg & 15 \\
\hline Tijd met kinderen & 15 \\
\hline
\end{tabular}

Bron: ROA LLL enquête, 2017

Tabel 1.3 geeft een overzicht van de bruikbaarheid van de leeractiviteiten voor nietwerkenden. Aan hen is gevraagd in welke mate de opgedane kennis en vaardigheden bruikbaar is in een eventueel volgende baan. Uit de tabel blijkt dat, net als bij de werkenden, de arbeidsmarktrelevantie van wat men leert van vrijwilligerswerk, mantelzorg en de tijd met kinderen beperkt is. Tijd besteed aan cursussen en zelfstudie is beter bruikbaar in een mogelijke volgende baan, al is de bruikbaarheid van cursussen en zelfstudie voor niet-werkenden op de arbeidsmarkt veel minder groot dan voor werkenden.

\subsection{Trends in de kennisontwikkeling}

Wanneer men tijd besteedt aan een vorm van leren, dan zal men naar verwachting nieuwe kennis en vaardigheden ontwikkelen. Om deze kennisontwikkeling in kaart te kunnen brengen worden respondenten in de ROA Levenslang Leren Enquête gevraagd een inschatting te maken over hun eigen kennisniveau op twee momenten: op het moment van de enquête en twee jaar geleden. Hierbij wordt aangegeven dat 100 het niveau is dat nodig zou zijn om optimaal te functioneren in het huidige werk. ${ }^{22}$ De kennisontwikkeling wordt dan gemeten als het verschil tussen het kennisniveau nu en twee jaar geleden. ${ }^{23}$

Werkenden hadden in 20179 procentpunt meer kennis en vaardigheden dan twee jaar daarvoor.
Figuur 1.16 laat zien dat de kennisontwikkeling die werkenden in de twee voorgaande jaren realiseerden door de jaren heen vrij

22 Bij niet werkenden wordt gevraagd naar het kennisniveau voor het werk dat men zou willen doen.

23 Omdat de 2004-2013 peilingen van de ROA Levenslang Leren Enquête afgenomen zijn in de DNB panel kan de kennisontwikkeling op individueel niveau ook gemeten worden aan de hand van het verschil in kennisniveau tussen twee peilingen. Voor alle opleidingsniveaus is sprake van een positieve en significante correlatie tussen de kennisontwikkeling aldus gemeten en de kennisontwikkeling gemeten als het verschil tussen de inschatting van het kennisniveau nu en twee jaar geleden. 
constant is. Alleen 2013 wijkt significant af, in dat jaar was de kennistoename onder werkenden 7 procentpunt. Een meting later in 2017 is de kennistoename in de afgelopen twee jaar weer gestegen tot 9 procentpunt.

FIGUUR 1.16 Kennisontwikkeling: ontwikkeling van de toename van kennis en vaardigheden van werkenden in de afgelopen twee jaar, 2004-2017

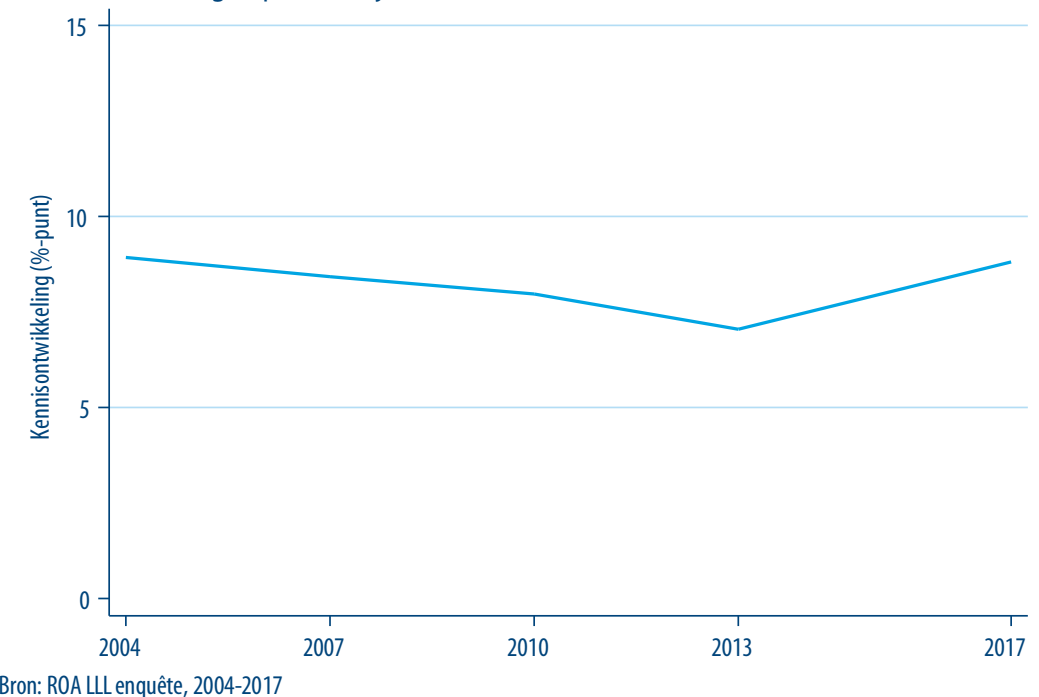

Bron: ROA LLL enquête, 2004-2017

De kennisontwikkeling neemt af naarmate de leeftijd toeneemt; desondanks ontwikkelen 50-plussers zich meer dan in voorgaande jaren
De trend in de kennisontwikkeling van werkenden naar leeftijd wordt in Figuur 1.17 weergegeven. Uit de figuur blijkt dat voor alle enquêtejaren de kennisontwikkeling kleiner wordt met het toenemen van de leef-

tijd. Voor de 50-plussers is er echter een positieve ontwikkeling zichtbaar. Wij zagen al eerder dat deze groep vaker cursussen is gaan volgen in de loop der tijd. Figuur 1.17 laat zien dat voor deze groep de kennisontwikkeling in 2017 op een hoger niveau ligt dan in de voorgaande jaren.

\section{Kennisontwikkeling en leren}

Uit analyses met de 2017 data waarin gecontroleerd wordt voor iemands geslacht, opleidingsniveau en leeftijd, blijkt dat de kennisontwikkeling van werkenden in de afgelopen twee jaar positief gecorreleerd is met de trainingsdeelname (maar slechts significant op 
een 10 procent-niveau) en het informeel leren. ${ }^{24}$ Daarentegen is er geen significante relatie met de tijd besteed aan zelfstudie en informeel leren buiten het werk (mantelzorg, vrijwilligerswerk en tijd met kinderen). Werkenden die in de afgelopen twee jaar van werkgever of van functie zijn veranderd blijken een sterkere kennisontwikkeling te hebben. ${ }^{25}$ Dit is in lijn met de eerdere bevinding dat werkenden die van functie zijn veranderd ook meer informeel leren op hun werk. Dit suggereert dat het met enige regelmaat veranderen van functie of takenpakket goed is voor het verwerven van nieuwe kennis. Andersom kan het echter ook zo zijn dat werkenden die nieuwe uitdagingen aangaan op het werk in de vorm van een andere functie of een andere werkgever ook personen zijn die bereid zijn zich verder te ontwikkelen. Nader onderzoek zou hier meer licht moeten werpen op de causale relaties.

FIGUUR 1.17 Kennisontwikkeling van werkenden in de afgelopen twee jaar naar leeftijd, 2004-2017

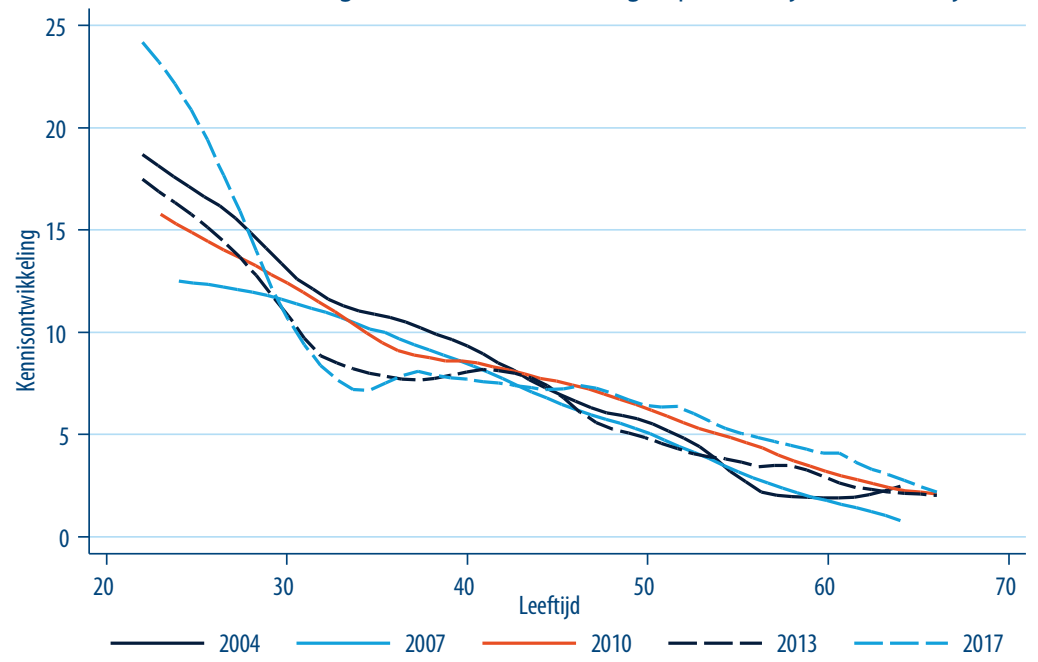

Bron: ROA LLL enquête, 2004-2017

24 Uit analyses met alle jaargangen van de ROA Levenslang Leren Enquête blijkt dat de relatie tussen kennisontwikkeling en trainingsdeelname en informeel leren significant is op $1 \%$. Maar dit betekent nog niet dat er sprake is van aan causale relatie. Om hier meer zicht op te geven is op basis van de 2004-2013 data een panelmodel geschat met het kennisniveau als afhankelijke variabele en trainingsdeelname en informeel leren als verklarende variabelen (naast opleiding, leeftijd en jaar dummy's). In een random effect specificatie is trainingsdeelname positief en significant gecorreleerd met het kennisniveau voor de hele steekproef en voor alleen werkenden. In een fixed effects specificatie (dat beter rekening houdt met individu-specifieke kenmerken die selectiviteit in trainingsdeelname zouden kunnen bepalen) is dit niet het geval, maar identificatie van effecten in dit geval berust op de aanwezigheid van respondenten die 2 keer of meer in de survey zijn waargenomen en dit zijn slechts ongeveer $40 \%$ van de beschikbare cases. De puntschatting voor het effect van training is in dit geval niet significant anders dan dat in het random effects model.

Dit geldt tevens voor 50-plussers. 



\section{TAKEN EN LEREN OP HET WERK}

De beslissing om scholing te gaan volgen kan verschillende redenen hebben. Werkgevers kunnen bijvoorbeeld beslissen om een cursus te faciliteren omdat zij vinden dat hun werknemers bepaalde vaardigheden missen, of omdat de aard van het werk verandert. Werknemers kunnen zelf investeren in scholing wanneer zij bepaalde loopbaandoelen hebben, het gevoel hebben dat zij bepaalde vaardigheden moeten bijspijkeren of omdat veranderingen in de aard van hun werkzaamheden dit noodzakelijk maken.

In dit hoofdstuk brengen wij in kaart hoe enerzijds de taken en vaardigheden die belangrijk zijn op het werk en anderzijds het formeel en informeel leren aan elkaar gerelateerd zijn. Deze taken en vaardigheden zijn gemeten in de 2012 en 2017 peilingen van de Nederlandse Skills Survey (NSS). Om de relatie tussen het leren en de veranderingen in het werk in kaart te brengen kijken we ook naar technologische en organisatorische ontwikkelingen op het werk, zoals deze gerapporteerd worden door de respondenten in de ROA Levenslang Leren Enquête 2017. In paragraaf 2.1 gaan wij eerst in op de link tussen formeel leren en de taken die iemand op het werk heeft. Vervolgens gaat paragraaf 2.2 in op de relatie tussen informeel leren en iemands taken. Tot slot leggen wij in paragraaf 2.3 de relatie tussen iemands kennisontwikkeling en taken.

\subsection{Leren en het belang van taken op het werk}

\section{Beschrijvende resultaten}

Rekenvaardigheden worden het minst genoemd als belangrijke taak op het werk. Probleemoplossend vermogen daarentegen juist het meest.
In de NSS worden de respondenten gevraagd om voor een 35 -tal taken aan te geven in hoeverre deze taken belangrijk zijn in het huidige werk. Deze 35 taken aggregeren we vervolgens in een achttal groepen taken, te weten: interpersoonlijke vaardigheden, rekenvaardigheden, taal vaardigheden, fysieke kracht, probleemoplossend vermogen, plannen en organiseren, kennis van organisatie en gebruik van computer. ${ }^{26}$

26 Wij sluiten hierbij aan bij eerder onderzoek (Borghans et al, 2008). Welke taken onder welke groep vallen is terug te vinden in bijlage A.4. De taken zijn gegroepeerd door het gemiddelde van de onderliggende taken per taakgroep uit te rekenen. 
Figuur 2.1 laat zien hoeveel procent van de werkenden aangeeft dat deze taken belangrijk zijn op het werk. Hierbij worden alleen de respondenten van de 2017 NSS meegenomen die ook de ROA Levenslang Leren Enquête 2017 hebben ingevuld. Uit de figuur blijkt dat het belang van de 35 taken op het werk erg uiteen loopt. Rekenvaardigheden zijn met afstand de minst belangrijke taak op het werk, voor slechts 19 procent van de werkenden zijn deze taken (zeer) belangrijk. Aanmerkelijk hoger ligt het percentage werkenden voor wie fysieke kracht, taal vaardigheden, kennis van de organisatie en gebruik van computers (zeer) belangrijk zijn: rond de 30 procent. Plannen en organiseren en interpersoonlijke vaardigheden worden nog vaker aangegeven als (zeer) belangrijke taken op het werk (respectievelijk 42 en 47 procent). Het belangrijkst is echter het probleemoplossend vermogen: 55 procent van de werkenden geeft aan dat probleemoplossend vermogen (zeer) belangrijk is voor hun huidige werk.

FIGUUR 2.1 Percentage van de werkenden dat aangeeft dat bepaalde taken (zeer) belangrijk zijn op hun werk, 2017

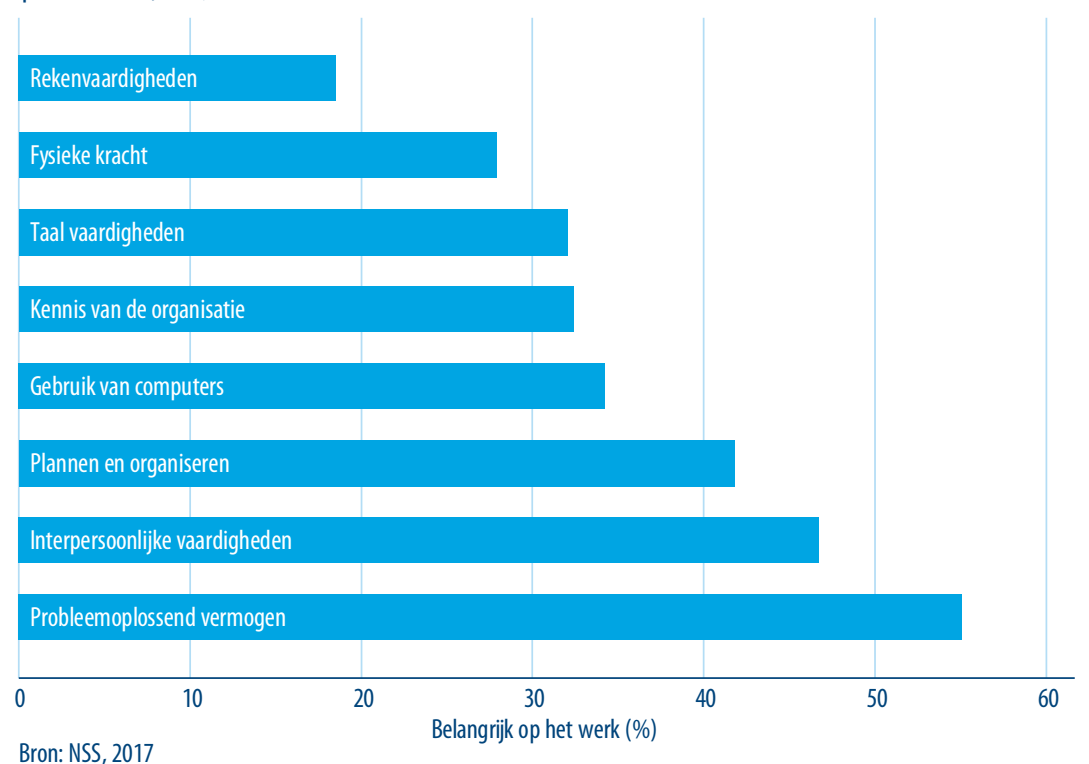

Vervolgens geeft Figuur 2.2 de verschillen weer in het percentage werkenden dat aangeeft dat bepaalde taken (zeer) belangrijk zijn op hun werk naar opleidingsniveau. ${ }^{27}$ Voor nagenoeg alle groepen taken zien we hetzelfde patroon, laagopgeleiden geven het minst vaak aan dat de taken belangrijk zijn op hun werk, middelbaar opgeleiden geven dit iets vaker aan maar hoogopgeleiden geven het vaakst aan dat de taken belangrijk zijn op hun werk. De enige uitzondering zijn fysieke taken die vaker belangrijk zijn op het werk voor laag- en middelbaar opgeleiden vergeleken met hoogopgeleiden.

27 In Bijlage A zijn ook de verschillen naar geslacht en leeftijd opgenomen. 
FIGUUR 2.2 Percentage werkenden dat aangeeft dat taken (erg) belangrijk zijjn, naar opleidingsniveau

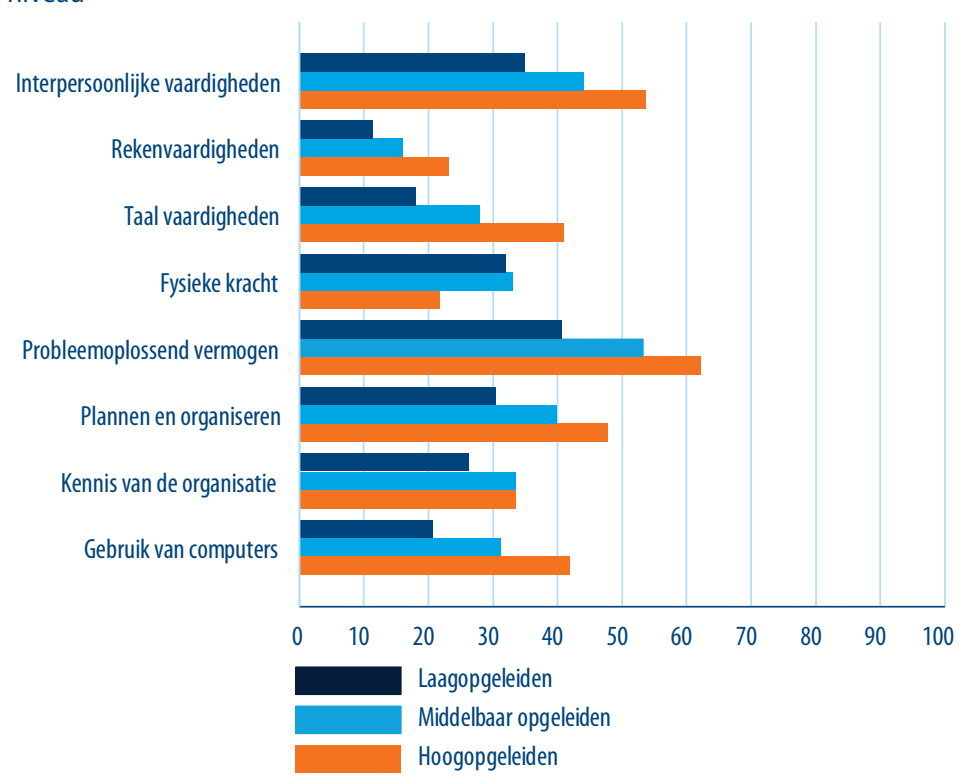

Bron: NSS, 2017

Naast het takenpakket van een werkende kan ook de mate waarin er sprake is van technologische en organisatorische veranderingen binnen het bedrijf invloed hebben op het leergedrag van de werkende. Technologische veranderingen zouden bijvoorbeeld de aard van de werkzaamheden kunnen veranderen, waardoor werkenden scholing nodig hebben om deze veranderingen bij te benen. Anderzijds zouden organisatorische veranderingen ervoor kunnen zorgen dat de aard van het werk of de functiestructuur veranderen, waardoor er bij- of omscholing nodig is om de werkende in de nieuwe functie optimaal te laten functioneren. Als een eerste beschrijving laat Figuur 2.3 zien in hoeverre de werkenden in de ROA Levenslang Leren Enquête aangeven te maken te hebben met technologische en organisatorische veranderingen.$^{28}$ De figuur laat zien dat het merendeel van de werkenden op hun werk te maken hebben met zowel technologische als organisatorische veranderingen. Een relatief groot percentage geeft zelfs aan dat er grote of zelfs zeer grote technologische en organisatorische ontwikkelingen plaatsvinden op het werk; respectievelijk 38 en 34 procent van alle werkenden.

28 Hoe technologische en organisatorische veranderingen gemeten zijn in de ROA Levenslang Leren Enquête wordt aangegeven in Tabel A.5 in de bijlage. 
FIGUUR 2.3 Mate waarin technologische en organisatorisch veranderingen op het werk effect hebben op de inhoud van het werk, 2017

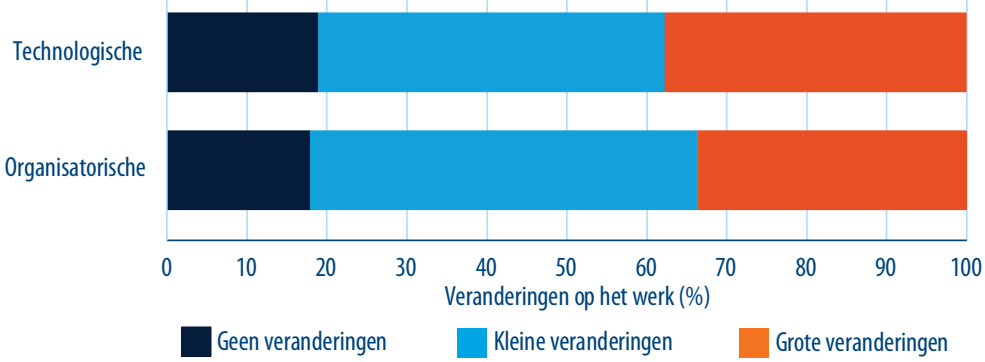

Bron: ROA LLL enquête, 2017

Het leergedrag ligt doorgaans hoger als interpersoonlijke vaardigheden, taalvaardigheden en probleemoplossend vermogen belangrijke taken op het werk zijn.
Tabel 2.1 laat zien welke relaties er zijn tussen het leergedrag van werkenden, het belang van de verschillende taken op hun werk en de mate waarin werkenden te maken hebben met technologische en organisatorische veranderingen op het werk. Uit deze tabel

blijkt dat voor een aantal taken de cursusdeelname hoger is wanneer de taak belangrijk is op het werk. Dit zien we namelijk bij interpersoonlijke vaardigheden, taalvaardigheden en probleemoplossend vermogen. Voor taalvaardigheden zien we zelfs een verschil van 13 procentpunt tussen werkenden voor wie de taak niet of wel belangrijk is op het werk. Fysieke kracht is de enige taak waar de cursusdeelname iets hoger ligt als de taak niet belangrijk is op het werk, maar dit verschil blijkt niet significant te zijn. Met betrekking tot het informeel leren van taken op het werk ligt het percentage hoger wanneer bepaalde taken belangrijk zijn op het werk: interpersoonlijke vaardigheden rekenvaardigheden, taalvaardigheden, probleemoplossend vermogen, plannen en organiseren en computergebruik. Interpersoonlijke vaardigheden is de taak waarvoor het verschil het grootst is: 10 procentpunt. lemands kennisontwikkeling (zie hoofdstuk 1) ligt voor alle taken hoger wanneer de taak belangrijk is op het werk, hoewel het verschil alleen significant is voor de taken interpersoonlijk vaardigheden en plannen en organiseren. Het grootste verschil is met 3 procentpunt te zien voor interpersoonlijke vaardigheden.

Hoe groter de veranderingen op het werk hoe hoger de cursusdeelname en het informeel leren van taken op het werk.
Bij de veranderingen op het werk zien we voor zowel technologische als organisatorische ontwikkelingen een duidelijk patroon: Onder werkenden die niet te maken hebben met veranderingen op het werk is zowel de cursusdeelname als het informeel leren op het werk het laagst. Werkenden die te maken hebben met kleine ontwikkelingen op het werk participeren meer in cursussen en leren informeel ook meer op hun werk. De cursusdeelname en het informeel leren op het werk ligt op een nog hoger niveau wanneer er grote veranderingen hebben plaats gevonden op het werk. De 
cursusdeelname neemt het snelst toe bij organisatorische veranderingen: De cursusdeelname van werkenden die te maken hadden met grote organisatorische veranderingen ligt maar liefst 26 procentpunt hoger dan bij werkenden die niet te maken hebben met organisatorische veranderingen op hun werk. De kennisontwikkeling onder werkenden lijkt ook toe te nemen wanneer de technologische of organisatorische veranderingen groter zijn, maar deze verschillen blijken niet significant te zijn.

TABEL 2.1 Cursusdeelname, informeel leren van taken op het werk en kennisontwikkeling naar het belang van taken en mate van verandering op het werk, 2017

\begin{tabular}{|c|c|c|c|c|}
\hline & & $\begin{array}{l}\text { Cursusdeelname } \\
\text { (\%) }\end{array}$ & $\begin{array}{l}\text { Informeel leren } \\
\text { van taken op het } \\
\text { werk (\%) }\end{array}$ & $\begin{array}{l}\text { Kennis- } \\
\text { ontwikkeling } \\
(\%)\end{array}$ \\
\hline \multicolumn{5}{|l|}{ Taken NSS } \\
\hline \multirow[t]{2}{*}{ Interpersoonlijke vaardigheden } & Niet belangrijk & 55 & 21 & 7 \\
\hline & Belangrijk & $64^{* * *}$ & $31^{* * *}$ & $10^{* *}$ \\
\hline \multirow[t]{2}{*}{ Rekenvaardigheden } & Niet belangrijk & 56 & 22 & 7 \\
\hline & Belangrijk & 56 & $26^{* *}$ & 9 \\
\hline \multirow[t]{2}{*}{ Taalvaardigheden } & Niet belangrijk & 54 & 21 & 7 \\
\hline & Belangrijk & $67^{* * *}$ & $28^{* * *}$ & 9 \\
\hline \multirow[t]{2}{*}{ Fysieke kracht } & Niet belangrijk & 56 & 22 & 7 \\
\hline & Belangrijk & 55 & 22 & 8 \\
\hline \multirow[t]{2}{*}{ Probleemoplossend vermogen } & Niet belangrijk & 52 & 21 & 7 \\
\hline & Belangrijk & $61^{* * *}$ & $25^{* * *}$ & 8 \\
\hline \multirow[t]{2}{*}{ Plannen en organiseren } & Niet belangrijk & 55 & 22 & 7 \\
\hline & Belangrijk & 59 & $25^{* * *}$ & $9^{* *}$ \\
\hline \multirow[t]{2}{*}{ Kennis van organisatie } & Niet belangrijk & 56 & 22 & 7 \\
\hline & Belangrijk & 59 & 23 & 8 \\
\hline \multirow[t]{2}{*}{ Gebruik van computer } & Niet belangrijk & 56 & 22 & 7 \\
\hline & Belangrijk & 56 & $27^{* * *}$ & 8 \\
\hline \multicolumn{5}{|l|}{ Veranderingen op het werk } \\
\hline \multirow[t]{3}{*}{ Grote technologische ontwikkelingen } & Geen & 41 & 16 & 7 \\
\hline & Kleine ontwikkelingen & $55^{* * *}$ & $22^{* * *}$ & 8 \\
\hline & Grote ontwikkelingen & $63^{* * *}$ & $26^{* * *}$ & 8 \\
\hline \multirow[t]{3}{*}{ Grote organisatorische ontwikkelingen } & Geen & 39 & 16 & 6 \\
\hline & Kleine ontwikkelingen & $55^{* * *}$ & $22^{* * *}$ & 7 \\
\hline & Grote ontwikkelingen & $65^{* * *}$ & $26^{* *}$ & 8 \\
\hline
\end{tabular}

*** $\mathrm{p}<0,01,{ }^{* *} \mathrm{p}<0,05,{ }^{*} \mathrm{p}<0,1$

Bron: ROA LLL enquête, 2017 \& NSS, 2017

1) Voor de taken testen we of het verschil in cursusdeelname, informeel leren en kennisontwikkeling significant verschilt naargelang het belang van taken. Met betrekking tot de veranderingen op het werk testen we de significantie van de verschillen tussen kleine ontwikkelingen en geen ontwikkelingen en tussen grote ontwikkelingen en kleine ontwikkelingen. 


\subsection{Multivariate analyses}

Om de relatie te onderzoeken tussen het leergedrag en de taken die iemand op het werk verricht voeren we een aantal regressie analyses uit waarin we rekening houden met andere verbanden (bijvoorbeeld het feit dat hoogopgeleiden vaak ook meer complexe banen hebben). Het in Tabel 2.1 gevonden verband tussen cursusdeelname en het moeten plannen en organiseren op het werk zou bijvoorbeeld het gevolg kunnen zijn van het feit dat hoger opgeleiden vaker leidinggevende functies bekleden waarin zij het werk van anderen moeten organiseren. Controleren voor iemands opleidingsniveau in de analyses maakt het mogelijk om het directe verband tussen taken en leren in kaart te brengen.

\section{Cursusdeelname en taken}

Hoe belangrijker interpersoonlijke vaardigheden, taalvaardigheden en probleemoplossend vermogen voor het werk zijn, hoe groter de kans dat de werkende een cursus heeft gevolgd. Deze kans neemt ook toe als de organisatorische veranderingen binnen het bedrijf groter zijn.
Uit Tabel 2.2 blijkt dat ook als we controleren voor een aantal achtergrondkenmerken van de respondenten en de sector waarin zij werkzaam zijn, het belang van taken op het werk een van de bepalende factoren is in het verklaren van de cursusdeelname van werkenden. De cursusdeelname is significant hoger wanneer het belang van interpersoonlijke vaardigheden, taalvaardigheden en probleemoplossend vermogen voor het uitvoeren van het werk groter is. Deze relaties blijven significant wanneer er wordt gecontroleerd voor de veranderingen op het werk en de situatie op de markt waarop het bedrijf actief is. Met betrekking tot de veranderingen op het werk zien we dat organisatorische ontwikkelingen in hoge mate samenhangen met de cursusdeelname. Zo ligt de kans op het volgen van een cursus bijna 15 procentpunten hoger wanneer er grote organisatorische ontwikkelingen op het werk plaatsvinden. Bij kleine organisatorische ontwikkelingen ligt de kans op cursusdeelname ongeveer 10 procentpunt hoger dan als er zich geen organisatorische ontwikkelingen voordoen. Merkwaardig genoeg vinden wij geen significant verband tussen technologische veranderingen op het werk en de cursusdeelname. ${ }^{29}$

29 Voordat wij controleren voor de sector van activiteit, bestaat er wel een verband tussen technologische veranderingen op het werk en cursusdeelname. 
TABEL 2.2 Relatie tussen cursusdeelname en het belang van iemands taken, 2017

\begin{tabular}{|c|c|c|}
\hline & (1) & (2) \\
\hline \multicolumn{3}{|l|}{ Taken in 2017} \\
\hline Interpersoonlijke vaardigheden & $0,080^{* * *}$ & $0,074^{* * *}$ \\
\hline Rekenvaardigheden & $-0,013$ & $-0,009$ \\
\hline Taalvaardigheden & $0,045^{* * *}$ & $0,041^{* * *}$ \\
\hline Fysieke kracht & 0,010 & 0,011 \\
\hline Probleemoplossend vermogen & $0,033^{*}$ & $0,029^{*}$ \\
\hline Plannen en organiseren & $-0,018$ & $-0,017$ \\
\hline Kennis van de organisatie & $-0,002$ & $-0,005$ \\
\hline Gebruik van computers & $-0,017$ & $-0,023$ \\
\hline \multicolumn{3}{|l|}{$\begin{array}{l}\text { Technologische ontwikkelingen } \\
\text { (ref: Geen ontwikkelingen) }\end{array}$} \\
\hline Kleine ontwikkelingen & & 0,027 \\
\hline Grote ontwikkelingen & & 0,042 \\
\hline \multicolumn{3}{|l|}{$\begin{array}{l}\text { Organisatorische ontwikkelingen } \\
\text { (ref: Geen ontwikkelingen) }\end{array}$} \\
\hline Kleine ontwikkelingen & & $0,096^{* * *}$ \\
\hline Grote ontwikkelingen & & $0,149^{* * *}$ \\
\hline \multicolumn{3}{|l|}{ Kenmerken van de markt } \\
\hline Sterke concurrentie op de markt & & $-0,033$ \\
\hline Sterke instabiliteit op de markt & & 0,011 \\
\hline Constante & $0,254^{* * *}$ & $0,218^{* * *}$ \\
\hline N & 1.776 & 1.767 \\
\hline R-kwadraat & 0,099 & 0,111 \\
\hline
\end{tabular}

*** $\mathrm{p}<0,01,{ }^{* *} \mathrm{p}<0,05,{ }^{*} \mathrm{p}<0,1$

Bron: ROA LLL enquête, 2017 \& NSS, 2017

Overige controlevariabelen: bedrijfssector, aantal jaren ervaring, geslacht, leeftijd, opleidingsniveau, het al dan niet hebben van een partner en het aantal kinderen.

Ook als er wordt gekeken naar het belang van iemands taken enkele jaren geleden, dan blijken werkenden in banen waarvoor interpersoonlijke vaardigheden en taalvaardigheden belangrijk zijn vaker een cursus te volgen. Ook volgen werkenden die te maken hebben met organisatorische ontwikkelingen op het werk vaker een cursus dan werkenden waarvoor dat niet het geval was.
Aangezien we de cursusdeelname in dit rapport meten over de afgelopen twee jaar, is het niet alleen belangrijk te kijken naar de relatie tussen cursusdeelname en het huidige belang van iemands taken, maar ook naar het belang van taken in het verleden. Daarmee kunnen we immers een beter beeld krijgen over in hoeverre de cursusdeelname samenhangt met het takenpakket van de werkende. Dit kunnen we doen door de $R O A$ Levenslang Leren Enquête 2017 te koppelen aan de NSS 2012. Zo kunnen we zien in hoeverre het belang van taken in 2012 resulteerde 
in cursusdeelname in de jaren daarna..$^{30}$ In Tabel 2.3 laten we de resultaten zien van deze analyse, waarbij we nu ook controleren voor de mogelijke verandering van baan tussen 2012 en 2017. Als men tussen die jaren van baan veranderd is, is het belang van de taken in 2012 immers minder relevant voor op de cursusdeelname in de afgelopen twee jaar.

TABEL 2.3 Relatie tussen cursusdeelname en het belang van iemands vroegere taken, 2017

\begin{tabular}{|c|c|c|}
\hline & (1) & (2) \\
\hline \multicolumn{3}{|l|}{ Taken in 2012} \\
\hline Interpersoonlijke vaardigheden & $0,059^{* *}$ & $0,057^{* *}$ \\
\hline Rekenvaardigheden & $-0,014$ & $-0,013$ \\
\hline Taalvaardigheden & $0,059^{* * *}$ & $0,051^{* * *}$ \\
\hline Fysieke kracht & $-0,000$ & 0,000 \\
\hline Probleemoplossend vermogen & 0,030 & 0,030 \\
\hline Plannen en organiseren & $-0,037^{* *}$ & $-0,036^{*}$ \\
\hline Kennis van de organisatie & 0,036 & $0,039^{*}$ \\
\hline Gebruik van computers & $-0,029$ & $-0,037^{* *}$ \\
\hline \multicolumn{3}{|c|}{ Technologische ontwikkelingen (ref: Geen ontwikkelingen) } \\
\hline Kleine ontwikkelingen & & 0,013 \\
\hline Grote ontwikkelingen & & 0,005 \\
\hline \multicolumn{3}{|c|}{ Organisatorische ontwikkelingen (ref: Geen ontwikkelingen) } \\
\hline Kleine ontwikkelingen & & $0,165^{* * *}$ \\
\hline Grote ontwikkelingen & & $0,188^{* * *}$ \\
\hline \multicolumn{3}{|l|}{ Kenmerken van de markt } \\
\hline Sterke concurrentie op de markt & & $-0,010$ \\
\hline Sterke instabiliteit op de markt & & $-0,029$ \\
\hline Veranderd van baan tussen 2012 en 2017 & 0,044 & $0,047^{*}$ \\
\hline Constante & $0,184^{*}$ & 0,090 \\
\hline N & 1.234 & 1.226 \\
\hline R-kwadraat & 0,115 & 0,130 \\
\hline
\end{tabular}

*** $\mathrm{p}<0,01,{ }^{* *} \mathrm{p}<0,05,{ }^{*} \mathrm{p}<0,1$

Bron: ROA LLL enquête, 2017 \& NSS, 2012

Overige controlevariabelen: bedrijfssector, aantal jaren ervaring, geslacht, leeftijd, opleidingsniveau, het al dan niet hebben van een partner en het aantal kinderen.

Tabel 2.3 laat zien dat ook wanneer we kijken naar de taken die in het verleden voor iemands werk belangrijk waren, de interpersoonlijke vaardigheden en taalvaardigheden positief samenhangen met de cursusdeelname. Verder zien we ook een positieve relatie tussen het belang van kennis van de organisatie en de cursusdeelname later in de carrière. Deze relatie is echter minder significant dan die voor de andere twee taken en alleen significant als er wordt gecontroleerd voor de veranderingen op het werk en de

30 Merk op dat de causaliteit ook andersom zou kunnen lopen. Als werkenden het zien aankomen dat taken belangrijker zaal worden in het werk, zullen zij meer investeren, en dus een hoog belang nu kan hebben geleid tot deelname aan trainingen en meer informeel leren in het verleden. 
situatie in de markt waarin het bedrijf actief is. Voor de taken plannen en organiseren en gebruik van computers zien we juist het tegenovergestelde: naarmate deze taken belangrijk waren in $\mathbf{2 0 1 2}$ gaat dit gepaard met een lagere cursusdeelname in de jaren daarna. Met betrekking tot de veranderingen op het werk zien we een vergelijkbaar beeld als in Tabel 2.2. Hoe groter de organisatorische veranderingen op het werk hoe hoger de cursusdeelname. De coëfficiënten zijn wel een groter dan in Tabel 2.2.

\section{Informeel leren en taken}

$\mathrm{Nu}$ we hebben gezien dat vooral het belang van interpersoonlijke vaardigheden en taalvaardigheden positief samenhangen met de cursusdeelname is het ook interessant om te kijken welke taken samenhangen met het informeel leren op het werk. Dit doen we door gelijksoortige analyses uit te voeren met het percentage informeel leren op het werk als afhankelijke variabele.

Interpersoonlijke vaardigheden en taalvaardigheden hangen positief samen met het informeel leren op het werk. Werkenden die te maken hebben met grote technologische of organisatorische ontwikkelingen leren ook significant meer van hun werkzaamheden.
Tabel 2.4 laat zien dat taken die interpersoonlijke vaardigheden en taalvaardigheden vereisen ook positief samenhangen met het informeel leren op het werk. Hoe belangrijker deze taken worden hoe meer er informeel geleerd wordt van het werk dat men doet. Vooral de relatie met werk waarvoor interpersoonlijke

vaardigheden belangrijk zijn is sterk. Bij alle overige taken is er geen significante relatie met het leren van het werk dat men doet. Wel zien we dat werkenden significant meer leren op hun werk als er sprake is van grote technologische en organisatorische ontwikkelingen. Werkenden die te maken hebben met grote technologische of organisatorische ontwikkelingen leren respectievelijk 5,1 procentpunt en 3,2 procentpunt meer dan werkenden die niet met dergelijke ontwikkelingen op het werk te maken hebben. ${ }^{31}$ suggereert dat werkenden vooral leren van hun werk in de eerste jaren dat ze bij een bedrijf werken. 
TABEL 2.4 Relatie tussen informeel leren van taken op het werk en het belang van iemands taken, 2017

\begin{tabular}{|c|c|c|}
\hline & (1) & (2) \\
\hline \multicolumn{3}{|l|}{ Taken in 2017} \\
\hline Interpersoonlijke vaardigheden & $3,899^{* * *}$ & $3,608^{* * *}$ \\
\hline Rekenvaardigheden & $-0,110$ & $-0,064$ \\
\hline Taalvaardigheden & $1,804^{* *}$ & $1,790^{* *}$ \\
\hline Fysieke kracht & $-0,313$ & $-0,306$ \\
\hline Probleemoplossend vermogen & 1,046 & 0,774 \\
\hline Plannen en organiseren & $-0,334$ & $-0,206$ \\
\hline Kennis van de organisatie & $-0,339$ & $-0,617$ \\
\hline Gebruik van computers & 0,139 & $-0,167$ \\
\hline \multicolumn{3}{|c|}{ Technologische ontwikkelingen (ref: Geen ontwikkelingen) } \\
\hline Kleine ontwikkelingen & & 2,096 \\
\hline Grote ontwikkelingen & & $5,139^{* * *}$ \\
\hline \multicolumn{3}{|c|}{ Organisatorische ontwikkelingen (ref: Geen ontwikkelingen) } \\
\hline Kleine ontwikkelingen & & 2,170 \\
\hline Grote ontwikkelingen & & $3,204^{*}$ \\
\hline \multicolumn{3}{|l|}{ Kenmerken van de markt } \\
\hline Sterke concurrentie op de markt & & $-0,067$ \\
\hline Sterke instabiliteit op de markt & & $-0,166$ \\
\hline Constante & 4,492 & 3,433 \\
\hline $\mathrm{N}$ & 1.774 & 1.767 \\
\hline R-kwadraat & 0,110 & 0,120 \\
\hline
\end{tabular}

*** $\mathrm{p}<0,01,{ }^{* *} \mathrm{p}<0,05,{ }^{*} \mathrm{p}<0,1$

Bron: ROA LLL enquête, 2017 \& NSS, 2017

Overige controlevariabelen: bedrijfssector, aantal jaren ervaring, geslacht, leeftijd, opleidingsniveau, het al dan niet hebben van een partner en het aantal kinderen.

\section{Kennisontwikkeling en taken}

Als laatste gaan we in deze paragraaf in op de vraag of iemands takenpakket en de technologische en organisatorische ontwikkelingen op het werk van invloed zijn op iemands kennisontwikkeling. In Tabel 2.5 doen we dit door de relatie te onderzoeken tussen de kennisontwikkeling in de afgelopen twee jaar en het belang van de verschillende taken die iemand in 2017 verrichtte. Vervolgens presenteren we in Tabel 2.6 de resultaten van een vergelijkbare analyse waarin we kijken naar het belang van de taken die iemand in 2012 uitvoerde.

De taken die iemand uitoefent hebben geen effect op iemands kennisontwikkeling in de afgelopen twee jaar. Meer concurrentie op de afzetmarkt van het bedrijf zorgt daarentegen wel voor een hogere kennisontwikkeling.
Uit Tabel 2.5 blijkt dat het belang van de taken die iemand in 2017 op het werk verrichtte geen invloed lijkt te hebben op de kennisontwikkeling in de afgelopen twee jaar. Hetzelfde geldt voor de technologische 
en organisatorische ontwikkelingen op het werk; ook hier vinden we geen significante relaties met iemand kennisontwikkeling. Het enige dat een rol lijkt te spelen is de concurrentie op de afzetmarkt waarop de organisatie waar iemand werkt actief is. Hoe sterker deze concurrentie, hoe hoger de kennisontwikkeling..$^{32}$ Dit suggereert dat de kennisontwikkeling van medewerkers erg belangrijk is voor de concurrentiepositie van een bedrijf, maar kan aan de andere kant ook betekenen dat medewerkers veel kennis ontwikkelen als het bedrijf waar ze werken veel concurrentie heeft op zijn afzetmarkt.

TABEL 2.5 Relatie tussen kennisontwikkeling en het belang van iemands taken, 2017

\begin{tabular}{|c|c|c|}
\hline & (1) & (2) \\
\hline \multicolumn{3}{|l|}{ Taken in 2017} \\
\hline Interpersoonlijke vaardigheden & 1,258 & 0,932 \\
\hline Rekenvaardigheden & $-0,627$ & $-0,734$ \\
\hline Taalvaardigheden & $-0,217$ & $-0,178$ \\
\hline Fysieke kracht & $-0,392$ & $-0,381$ \\
\hline Probleemoplossend vermogen & $-0,297$ & $-0,407$ \\
\hline Plannen en organiseren & 0,906 & 1,005 \\
\hline Kennis van de organisatie & 0,664 & 0,618 \\
\hline Gebruik van computers & $-0,223$ & $-0,257$ \\
\hline \multicolumn{3}{|c|}{ Technologische ontwikkelingen (ref: Geen ontwikkelingen) } \\
\hline Kleine ontwikkelingen & & $-0,644$ \\
\hline Grote ontwikkelingen & & 1,376 \\
\hline \multicolumn{3}{|c|}{ Organisatorische ontwikkelingen (ref: Geen ontwikkelingen) } \\
\hline Kleine ontwikkelingen & & $-0,015$ \\
\hline Grote ontwikkelingen & & $-0,001$ \\
\hline \multicolumn{3}{|l|}{ Kenmerken van de markt } \\
\hline Sterke concurrentie op de markt & & $2,879^{* * *}$ \\
\hline Sterke instabiliteit op de markt & & $-1,131$ \\
\hline Constante & $8,415^{* * *}$ & $8,408^{* * *}$ \\
\hline N & 1.765 & 1.765 \\
\hline R-kwadraat & 0,088 & 0,096 \\
\hline \multicolumn{3}{|l|}{${ }^{* * *} p<0,01,{ }^{* *} p<0,05,{ }^{*} p<0,1$} \\
\hline Bron: ROA LLL enquête, 2017 \& NSS, 2017 & & \\
\hline
\end{tabular}

Overige controlevariabelen: bedrijfssector, aantal jaren ervaring, geslacht, leeftijd, opleidingsniveau, het al dan niet hebben van een partner en het aantal kinderen,

32 Dit geldt ook wanneer wij daarnaast controleren voor cursusdeelname en informeel leren van taken op het werk. 
lemands kennisontwikkeling is groter als zij in het verleden taken heeft uitgevoerd waarvoor taalvaardigheden of plannen en organiseren belangrijk waren. Wanneer het gebruik van computers belangrijk was in 2012 is de kennisontwikkeling in de jaren daarna juist lager.

termijn. ${ }^{33}$
Tabel 2.6 laat zien dat het belang van de taken die iemand in 2012 uitoefende wel een significante relatie heeft met iemands latere kennisontwikkeling: Bij het gebruik van computers zien we juist het tegenovergestelde. Wanneer dit belangrijk was in 2012 zien we een lagere kennisontwikkeling op de middellange

TABEL 2.6 Relatie tussen kennisontwikkeling en het belang van iemands vroegere taken, 2017

\begin{tabular}{|c|c|c|}
\hline & (1) & $(2)$ \\
\hline \multicolumn{3}{|l|}{ Taken in 2012} \\
\hline Interpersoonlijke vaardigheden & $-0,962$ & $-1,128$ \\
\hline Rekenvaardigheden & 0,201 & 0,185 \\
\hline Taalvaardigheden & $1,837^{* * *}$ & $1,879^{* * *}$ \\
\hline Fysieke kracht & $-0,293$ & $-0,267$ \\
\hline Probleemoplossend vermogen & $-0,937$ & $-0,921$ \\
\hline Plannen en organiseren & $1,128^{*}$ & $1,148^{*}$ \\
\hline Kennis van de organisatie & 1,062 & 0,966 \\
\hline Gebruik van computers & $-1,356^{* *}$ & $-1,359^{* *}$ \\
\hline \multicolumn{3}{|c|}{ Technologische ontwikkelingen (ref: Geen ontwikkelingen) } \\
\hline Kleine ontwikkelingen & & $-0,218$ \\
\hline Grote ontwikkelingen & & 0,605 \\
\hline \multicolumn{3}{|c|}{ Organisatorische ontwikkelingen (ref: Geen ontwikkelingen) } \\
\hline Kleine ontwikkelingen & & $-1,089$ \\
\hline Grote ontwikkelingen & & 0,119 \\
\hline \multicolumn{3}{|l|}{ Kenmerken van de markt } \\
\hline Sterke concurrentie op de markt & & $2,141^{*}$ \\
\hline Sterke instabiliteit op de markt & & 0,022 \\
\hline Veranderd van baan tussen 2012 en 2017 & $3,629^{* * *}$ & $3,632^{* * *}$ \\
\hline Constante & 3,202 & 2,969 \\
\hline N & 1.226 & 1.226 \\
\hline R-kwadraat & 0,046 & 0,052 \\
\hline
\end{tabular}

*** $\mathrm{p}<0,01,{ }^{* *} \mathrm{p}<0,05,{ }^{*} \mathrm{p}<0,1$

Bron: ROA LLL enquête, 2017 \& NSS, 2012

Overige controlevariabelen: bedrijfssector, aantal jaren ervaring, geslacht, leeftijd, opleidingsniveau, het al dan niet hebben van een partner en het aantal kinderen

33 Dit geldt ook wanneer wij daarnaast controleren voor cursusdeelname en informeel leren van taken op het werk. 
Wanneer een werkende tussen 2012 en 2017 van baan is veranderd, dan is de kennisontwikkeling groter.
Naast het belang van iemands taken op het werk zien we opnieuw dat bij de werkenden bij organisaties die een grotere concurrentie ondervinden op hun afzetmarkt de

kennisontwikkeling groter is. Dit verband is echter wel minder significant dan in Tabel 2.5. Verder blijkt het voor de kennisontwikkeling erg bepalend te zijn of iemand van baan veranderd is. Wanneer dit het geval is ligt de kennisontwikkeling over de afgelopen twee jaar namelijk 3,6 procentpunt hoger. 



\section{LEREN, EXTERNE EMPLOYABILITY EN MOBILITEIT}

Door flexibilisering, internationalisering en automatisering verandert de vraag naar vaardigheden op de arbeidsmarkt. In deze context is het niet alleen van belang dat het initieel onderwijs goed inspeelt op de veranderende marktomstandigheden, maar is het ook van belang dat werkenden hun kennis up-to-date houden om volwaardig te kunnen deelnemen in het arbeidsproces en productief inzetbaar te blijven in hun baan wanneer de functie-eisen veranderen of in andere banen wanneer de eigen baan zou komen te vervallen. Verschillende studies hebben laten zien dat het volgen van scholing een positief effect heeft op iemands productiviteit en inkomen (Dearden et al. 2006; De Grip \& Sauermann 2012). Groot en Maassen van den Brink (2000) laten zien dat werk gerelateerde scholing gerelateerd zijn aan de interne en externe employability.

In dit hoofdstuk gaan wij in op de relatie tussen leren en duurzame inzetbaarheid in de vorm van externe employability en baanmobiliteit. Allereest worden in paragraaf $3.1 \mathrm{de}$ ontwikkelingen in de externe employability en baanmobiliteit van werkenden tussen 2004 en 2017 besproken. Vervolgens relateren wij verschillende vormen van leren aan indicatoren voor externe employability en baanmobiliteit.

\subsection{Ontwikkelingen in externe employability en mobiliteit}

\section{Trendmatige ontwikkelingen}

In de ROA Levenslang Leren Enquête worden vier vragen gebruikt om de externe employability, het risico op baanverlies en baanmobiliteit in kaart te kunnen brengen (zie Tabel $A 3$ in bijlage A). Voor het bepalen van iemands externe employability worden de respondenten gevraagd een inschatting te maken van de kans dat als ze nu op zoek zouden moeten naar een andere baan, ze een baan zouden kunnen krijgen op een vergelijkbaar niveau als hun huidige baan. ${ }^{34}$ Verder wordt de respondenten gevraagd hoe groot de kans is dat zij in de komende vijf jaar hun baan verliezen. Om een indicatie te kunnen krijgen van iemands mobiliteit wordt de vraag gesteld om men over vijf jaar graag bij een ander bedrijf zou willen werken en of men verwacht over vijf jaar ook daadwerkelijk bij een ander bedrijf te werken. Deze vragen zijn beantwoord op een

34 Deze vraag is aan werkenden in loondienst, familiebedrijf en zelfstandigen gevraagd. Voor de overige drie vragen zijn de werkenden binnen een familiebedrijf en zelfstandigen niet bevraagd. 
schaal van 1 (zeer onwaarschijnlijk) tot 5 (zeer waarschijnlijk)..$^{35}$ Hoewel het hier gaat om subjectieve inschattingen door de respondenten zelf, en niet om een objectieve vaststelling van de mate van employability, is dit wel relevante informatie omdat verwachtingen bepalend zijn voor feitelijk arbeidsmarktgedrag. Figuur 3.1 laat de resultaten zien die voortkomen uit de gestelde vragen.

Gepercipieerde externe employability en baanzekerheid lagen tijdens de crisisjaren 2010 en 2013 op een lager niveau dan in 2007. Externe employability blijft in 2017 stabiel, maar de kans op baanverlies wordt lager ingeschat.

Uit Figuur 3.1 blijkt dat werkenden gemiddeld genomen hun externe employability (dat wil zeggen de kans dat ze een vergelijkbare baan zullen vinden wanneer ze hun huidige baan kwijt zouden raken) in schatten als 50-50. Verder geven ze aan dat er een kleine kans is dat ze in de komende vijf jaar hun baan zullen verliezen. Met betrekking tot de trend over de vijf enquêtejaren zien we een duidelijke relatie met de economische crisis. Tussen 2007 en de crisisjaren 2010 en 2013 neemt de externe employability van werkenden significant af en in 2017 schatten de werkenden hun externe employability nog op een vergelijkbaar niveau als in 2013. Dit suggereert dat het vertrouwen in goede baankansen als gevolg van het economisch herstel nog niet helemaal terug is. Tijdens de crisisjaren neemt ook de baanzekerheid af; men schat het risico op baanverlies met name in 2013 hoger in dan in de overige jaren. In 2017 wordt de kans om in de komende vijf jaar de huidige baan te verliezen weer significant lager ingeschat.

Baanmobiliteit wordt binnen de ROA Levenslang Leren Enquête sinds 2007 gemeten door middel van twee indicatoren: risico op baanverlies en baanmobiliteit in de komende vijf jaar. De hoogte van beide indicatoren is in alle enquêtejaren vrij stabiel. Daarbij blijkt dat werkenden in alle jaren gemiddeld genomen vaker aangeven dat ze over vijf jaar bij een ander bedrijf willen werken dan dat zij denken dat dit werkelijk zal gebeuren.

De kloof in gepercipieerde externe employability tussen hoog- en laagopgeleiden is tussen 2004 en 2017 gegroeid.

Hoogopgeleiden schatten hun externe employability in 2017 significant hoger in dan middelbaar opgeleiden. Laagopgeleiden schatten hun externe employability juist lager in. De kloof in de perceptie van hun eigen externe employability tussen laag en hoogopgeleiden is tussen 2004 en 2017 gegroeid. Een mogelijke verklaring hiervoor is dat de opleidingseisen van werkgevers stijgen (Van den Berge \& Ter Weel, 2015; Bijlsma et al., 2015). Het is vanuit dat perspectief opmerkelijk dat het risico op baanverlies door de werkenden op de verschillende opleidingsniveaus niet significant anders wordt ingeschat.

35 Bij de vraag of de respondent over vijf jaar graag bij een ander bedrijf zou willen werken is gebruik gemaakt van andere labels: zeker niet (1) tot erg graag (5). 
FIGUUR 3.1 Verwachtingen van werkenden over hun externe employability, risico op baanverlies en baanmobiliteit in komende vijf jaar, 2004-2017

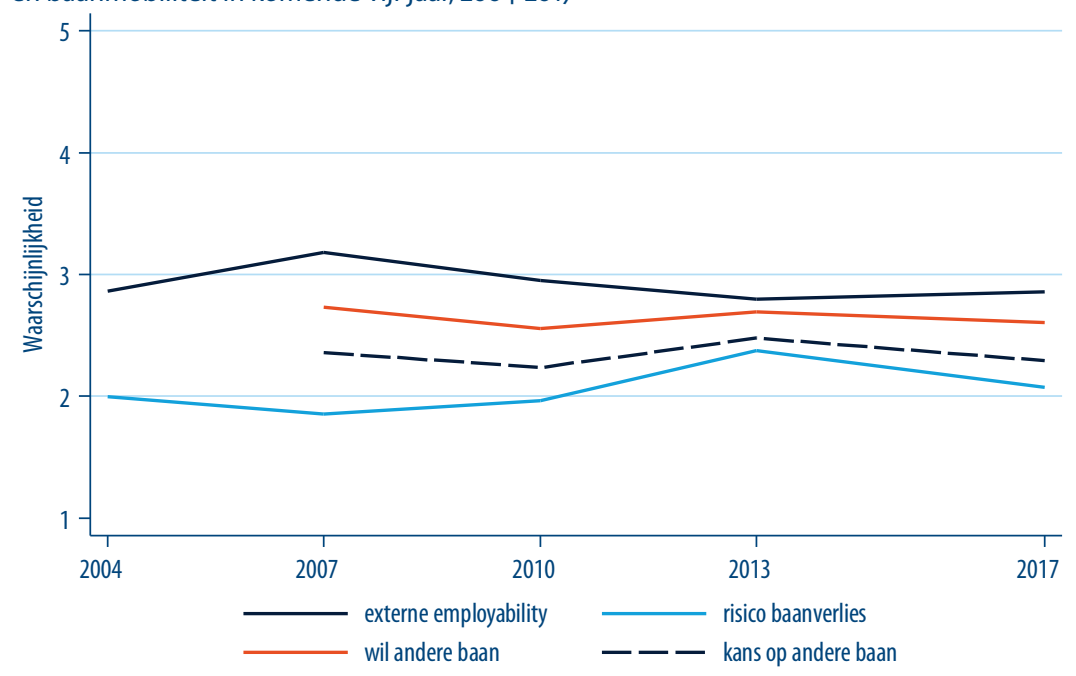

Bron: ROA LLL enquête, 2004-2017

FIGUUR 3.2 Ontwikkeling van de gepercipieerde externe employability van werkenden naar leeftijd, 2004-2017

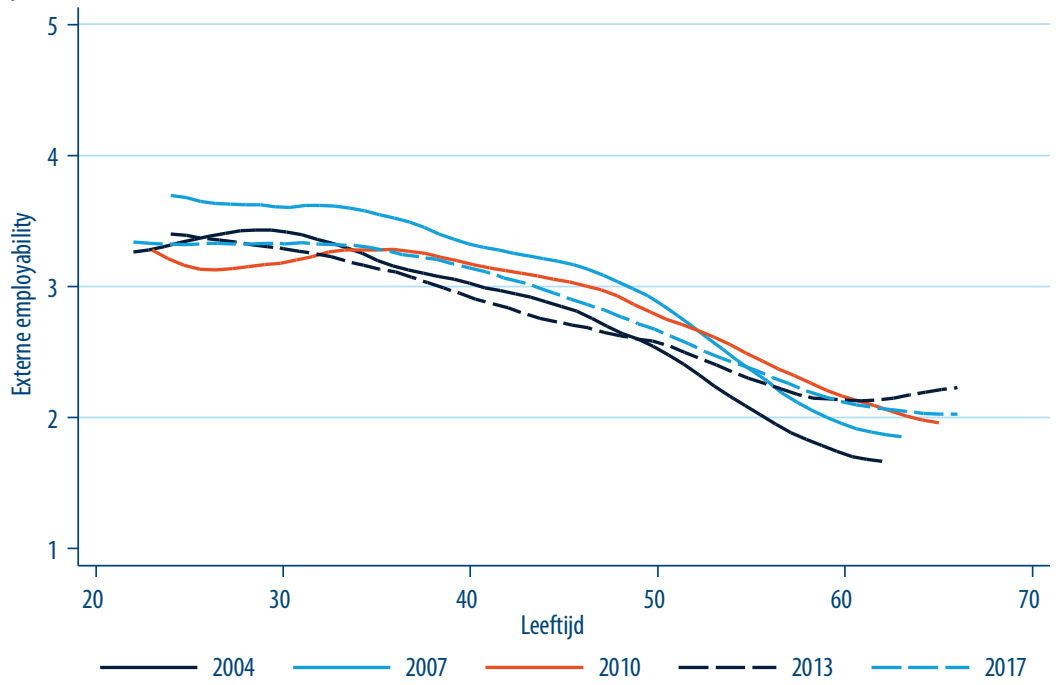

Bron: ROA LLL enquête, 2004-2017 
Ouderen schatten hun externe employability lager in dan jongeren, maar het verschil tussen jong en oud wordt kleiner.

Figuur 3.2 laat de ontwikkeling van de externe employability onder werkenden naar leeftijd zien. Voor alle enquêtejaren zien we dat oudere werkenden hun externe employability minder hoog inschatten dan jongeren. Jongeren geven gemiddeld genomen aan dat de kans om een baan op vergelijkbaar niveau te vinden hoger ligt dan 50 procent; ouderen geven aan dat deze kans klein is. De externe employability van oudere werkenden blijkt echter wel te verbeteren en ligt in de recentere enquêtejaren duidelijk hoger dan in 2004 en 2007. De kleiner wordende kloof in de externe employability tussen jong en oud is opmerkelijk, omdat de langdurige werkloosheid onder ouderen een groeiend probleem is (de Graaf-zijl et al., 2015). Het is echter wel in lijn met de in de afgelopen jaren sterk gestegen arbeidsparticipatie van 60-plussers.

In alle leeftijdsgroepen schatten werkenden in 2013 de kans om hun baan te verliezen hoger in dan in eerdere en latere jaren.

baan te verliezen veel hoger lag dan in de andere jaren.

FIGUUR 3.3 Ontwikkeling van de gepercipieerde kans op baanverlies in de komende 5 jaar naar leeftijd, 2004-2017

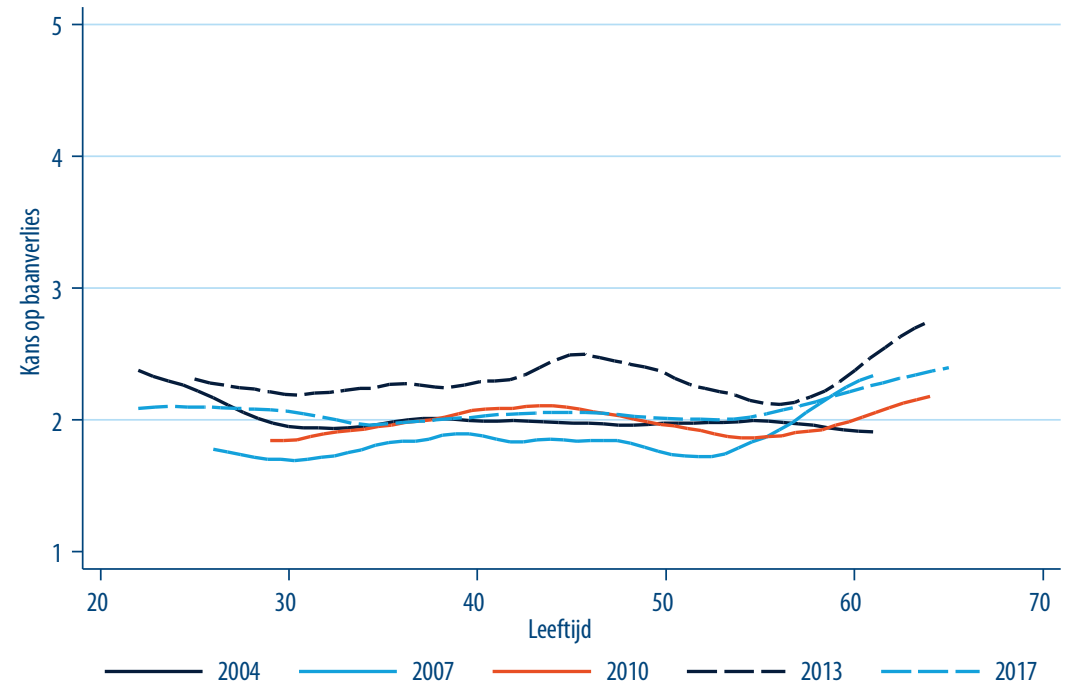

Bron: ROA LLL enquête, 2004-2017 
Werkenden in de sector landbouw schatten hun externe employability het laagst in; werkenden in de sector zakelijke dienstverlening het hoogst.
In Figuur 3.4 wordt de inschatting van de externe employability in 2017 gedifferentieerd naar bedrijfssector. Hoewel de verschillen tussen sectoren klein zijn, is de perceptie van de eigen externe employability onder werk-

enden in de landbouw, industrie en energiewinning het laagst. Een mogelijke verklaring is dat in deze sectoren, als gevolg van de inzet van arbeidsbesparende technologieën, de werkgelegenheid is gekrompen. Aan de andere kant schatten werkenden in de sector financiële instellingen en zakelijke dienstverlening hun eigen externe employability juist hoog in. Dit is merkwaardig omdat de prognoses voor de werkgelegenheidsontwikkeling in de financiële dienstverlening niet bepaald goed zijn (ROA, 2017). Een verklaring kan zijn dat werkenden in die sector hun kansen op een baan hoger inschatten dan nieuwkomers op de arbeidsmarkt doordat zij een bepaalde mate van arbeidservaring met zich dragen.

FIGUUR 3.4 Gepercipieerde externe employability van werkenden naar sector, 2017

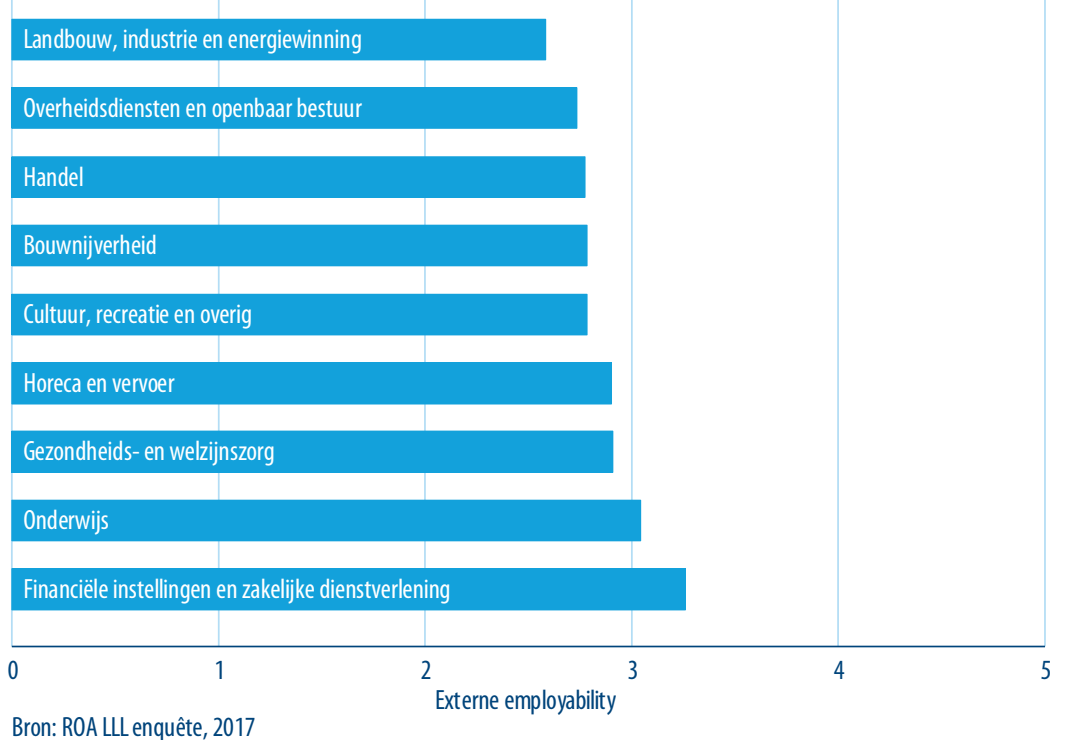

Bron: ROA LLL enquête, 2017

Werkenden in de sector financiële instellingen en zakelijke dienstverlening schatten de kans op baanverlies het hoogste in. Overheidsdiensten en openbaar bestuur en onderwijs zijn de sectoren waarin de werkenden juist het positiefst zijn over de eigen baanzekerheid
De inschatting van de kans op baanverlies kan eveneens naar sector gedifferentieerd worden (zie Figuur 3.5). Ook hier zijn de verschillen tussen sectoren niet groot. De sector financiële instellingen en zakelijke dienstverlening steekt er hier echter wel 
bovenuit. Waar de werkenden gemiddeld genomen in de meeste sectoren aangeven dat de kans op baanverlies klein is, zijn de werkenden in de sector financiële instellingen en zakelijke dienstverlening pessimistischer. In tegenstelling tot het beeld dat de werkenden in deze sector van hun externe employability hebben is dit meer in lijn met de prognoses van de werkgelegenheidsontwikkeling in de financiële dienstverlening (ROA, 2017). De sectoren waarin werkenden het risico op baanverlies het laagst inschatten zijn de sectoren overheidsdiensten en openbaar bestuur en onderwijs.

FIGUUR 3.5 Gepercipieerde kans op baanverlies in de komende 5 jaar naar sector, 2017

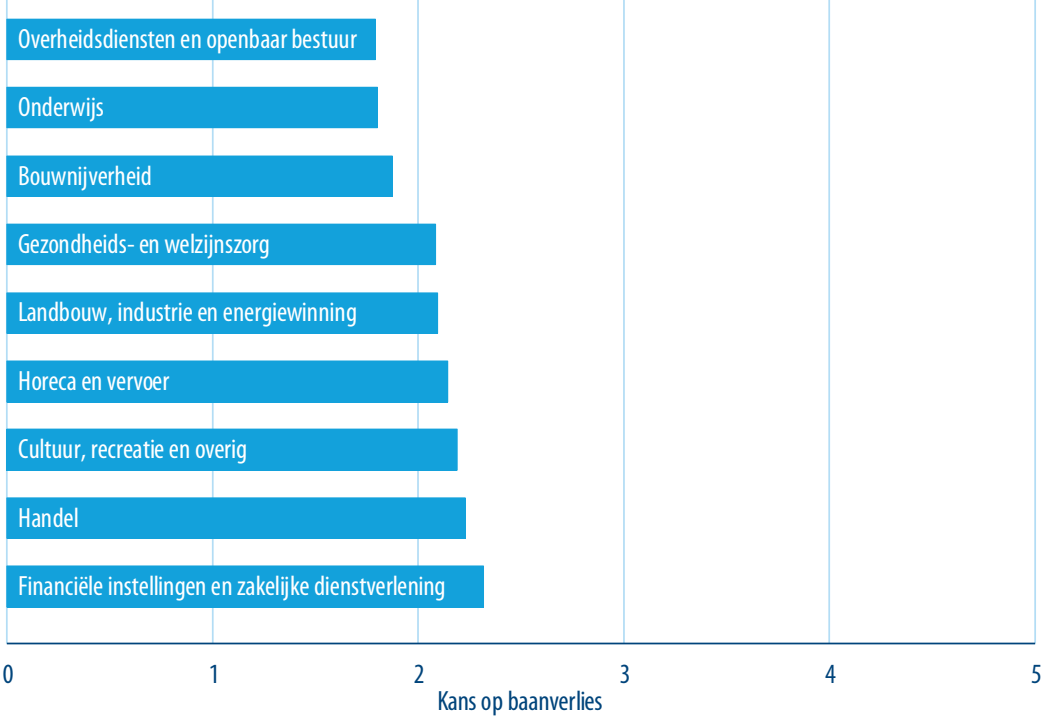

Bron: ROA LLL enquête, 2017

Zoals de Figuren 3.4 en 3.5 lieten zien, zijn er sectorale verschillen in de perceptie onder werkenden van hun externe employability en risico op baanverlies. In sommige sectoren geven beide indicatoren echter geen eenduidig beeld. Zo zagen we dat werkenden in de sector financiële instellingen en zakelijke dienstverlening aan de ene kant erg positief zijn over de eigen externe employability maar aan de andere kant het risico om hun baan te verliezen hoger inschatten dan de werkenden in andere sectoren. Dit suggereert dat de werkenden in deze sector weliswaar verwachten dat het risico op baanverlies groot is, maar optimistisch zijn over het vinden van een nieuwe baan. 
In alle sectoren schatten laag opgeleiden hun externe employability het laagste in en hoog opgeleiden juist het hoogst. De hoge externe employability van de werkenden in de sectoren financiële instellingen en zakelijke dienstverlening en het onderwijs is daardoor voor een belangrijk deel het gevolg van de oververtegenwoordiging van hoogopgeleiden in deze sectoren.
Om de sectorale verschillen beter te begrijpen kijken we in Figuur 3.6 naar de sectorale verschillen in de externe employability en het risico op baanverlies verbijzonderd naar opleidingsniveau. In alle sectoren zijn hoogopgeleiden het meest positief over hun eigen externe employability. Laagopgeleiden zijn daarentegen in alle sectoren het meest pessimistisch over hun eigen externe employability. Ook zien we dat in de sector financiële

instellingen en zakelijke dienstverlening vooral de hoogopgeleiden erg positief zijn over hun eigen externe employability, terwijl laag en middelbaar opgeleiden hun externe employability op eenzelfde niveau inschatten als de laag en middelbaar opgeleiden in andere sectoren. Omdat 64 procent van de werkenden in de sector financiële instellingen en zakelijke dienstverlening hoogopgeleid is, kan geconcludeerd worden dat het gunstige beeld van de externe employability van de werkenden in deze sector vooral het gevolg is van het positieve beeld dat hoogopgeleiden van hun externe employability hebben. Hetzelfde geldt voor de sector onderwijs, waar de bepalende factor van de hoogopgeleiden nog duidelijker te zien is. Laagopgeleiden in deze sector zijn namelijk het negatiefst van alle sectoren. Maar omdat deze sector voor 83 procent uit hoogopgeleiden bestaat die veel positiever zijn komt het sectorgemiddelde toch relatief hoog uit.

FIGUUR 3.6 Gepercipieerde externe employability en kans op baanverlies in de komende 5 jaar naar sector uitgesplitst naar opleidingsniveau, 2017

(a) Externe employability

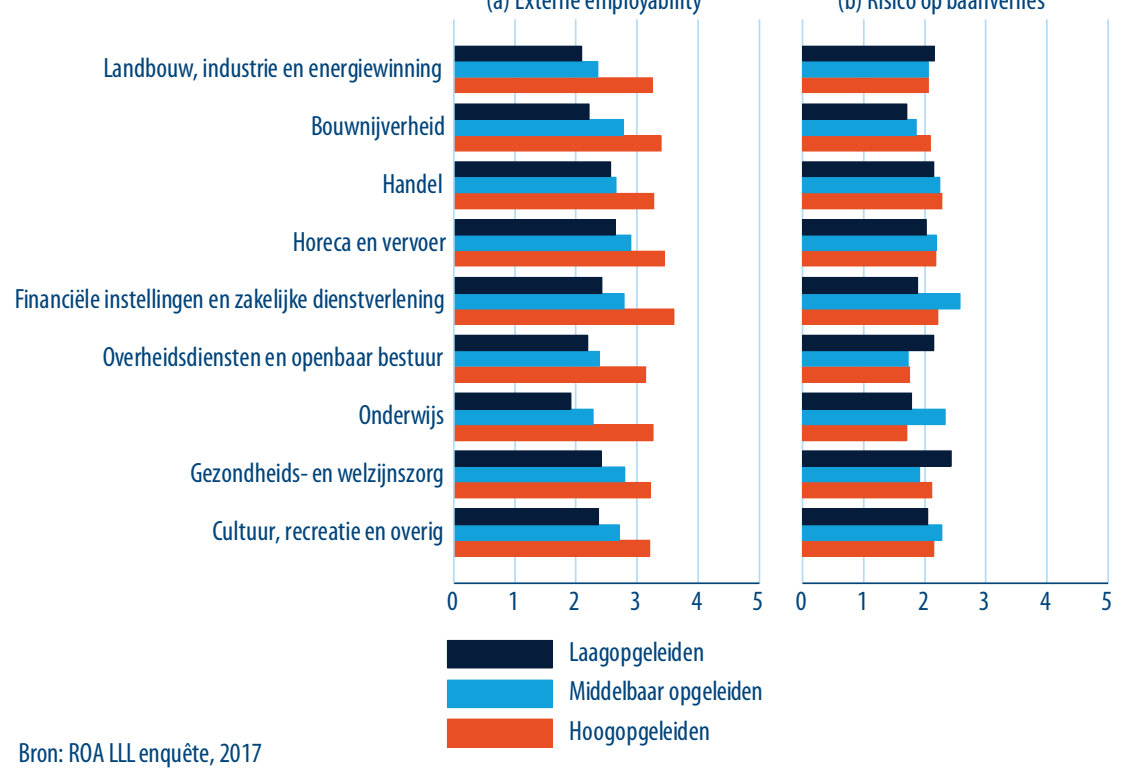


Het geschatte risico op baanverlies is erg afhankelijk van de sector waarin men werkt. Hoe hoog dit risico ingeschat wordt hangt samen met het automatiseringsrisico van het beroepen waarin iemand werkzaam is. opgeleiden het meest negatief zijn. Dit suggereert dat de inschatting van het risico op baanverlies erg afhankelijk is van de sector waarin men werkzaam is. Dit illustreert dat niet alle sectoren even gevoelig zijn voor veranderingen die de baanzekerheid van werknemers kunnen bedreigen. Zo zijn er veel verschillen in de kans op automatisering. Figuur 3.7 geeft een beeld van de relatie tussen het risico op baanverlies en de automatiseringskans naar beroep. ${ }^{36}$ De grootte van de rondjes weerspiegelt het aantal werkenden met het desbetreffende beroep. Uit de analyses blijkt dat er inderdaad een positieve relatie is tussen het risico op baanverlies en de automatiseringskans van het werk in het beroep. Hoe hoger de kans op automatisering binnen het beroep hoe hoger de werkenden het risico inschatten dat zij hun baan verliezen.

FIGUUR 3.7 Relatie tussen het ervaren risico op baanverlies en de automatiseringskans naar beroep, 2017

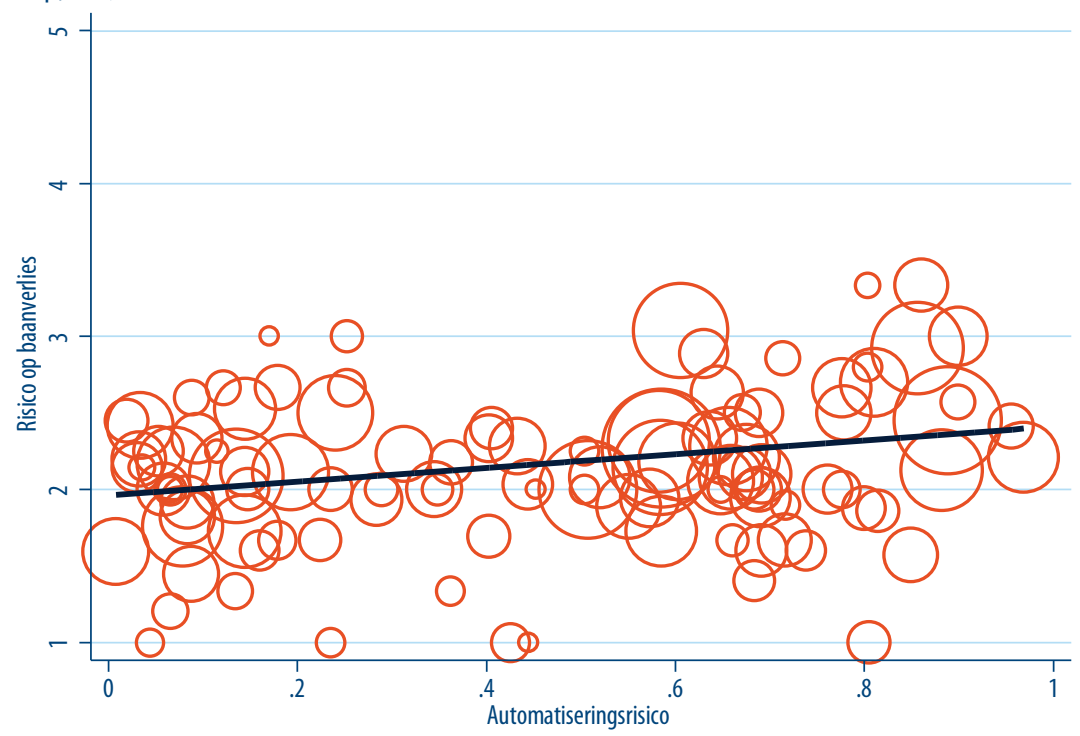

Bron: ROA LLL enquête, 2017 \& NSS, 2017 \& Deloitte

De automatiseringskans is van Deloitte (2014) 


\subsection{Informeel en formeel leren in relatie tot externe employability en mobiliteit}

Een voor de hand liggende vraag is in welke mate het leren op het werk, via cursussen dan wel het informeel leren van de taken die men verricht, de duurzame inzetbaarheid van werkenden kan vergroten. Tabel 3.1 laat zien in hoeverre het leergedrag verschilt naar gelang de inschatting over de eigen duurzame inzetbaarheid. Zo zien we een significant hogere cursusdeelname en een hoger percentage informeel leren van de taken op het werk onder werkenden die hun externe employability hoog inschatten. Voor het risico op baanverlies zien we het tegenovergestelde: werkenden met een hoge kans op baanverlies volgen zelfs 11 procentpunt minder vaak een cursus dan mensen met een lage kans op baanverlies. Dit zou echter kunnen samenhangen met het soort contract: uit eerder onderzoek weten wij immers dat tijdelijke krachten minder aanbod krijgen voor scholing van hun werkgever dan werkenden in vaste dienst (zie Fouarge et al, 2012; Künn-Nelen et al., 2018). Met deze verschillen laat Tabel 3.1 zien dat de externe employability en de duurzame inzetbaarheid van werkenden, duidelijk samenhangt met het beter op peil houden van hun competenties door cursusdeelname en informeel leren op het werk. ${ }^{37}$

TABEL 3.1 Relatie tussen leren en gepercipieerde externe employability en mobiliteit

\begin{tabular}{|l|l|l|l|}
\hline Externe employability & & $\%$ cursus gevolgd & $\%$ informeel leren \\
\hline Kans op baanverlies & laag & 52,9 & 21,2 \\
\hline & hoog & $60,7^{* * *}$ & $26,7^{* * *}$ \\
\hline Wil bij ander bedrijf werken & laag & 56,6 & 23,4 \\
\hline & hoog & $45,6^{* * *}$ & $19,9^{* *}$ \\
\hline Kans om bij een ander bedrijf te werken & laag & 56,1 & 23,0 \\
\hline & hoog & 53,0 & 23,1 \\
\hline
\end{tabular}

*** $\mathrm{p}<0,01,{ }^{* *} \mathrm{p}<0,05,{ }^{*} \mathrm{p}<0,1$

Bron: ROA LLL enquête, 2017

In het vervolg van deze paragraaf presenteren wij de uitkomsten van multivariate analyses met betrekking tot de in Tabel 3.1 getoonde relaties. De multivariate analyses zijn van belang omdat correlaties tussen leren en indicatoren van externe employability het resultaat kunnen zijn van andere factoren. Hoogopgeleiden nemen bijvoorbeeld vaker deel aan cursussen (hoofdstuk 1 ) en schatten hun externe employability hoger in (paragraaf 3.1). Een positieve relatie tussen cursusparticipatie en externe employability zou dus het gevolg kunnen zijn van het opleidingsniveau van werkenden. In deze multivariate analyses gaan wij tevens in op specifiekere kenmerken van cursussen (soort cursus, interne en externe bruikbaarheid) en informeel leren (interne en externe bruikbaarheid van de opgedane kennis en vaardigheden). ${ }^{38}$

37 We testen of het verschil in cursusdeelname en informeel leren significant verschilt naar de perceptie van de respondenten over externe employability, risico op baanverlies, het willen werken bij een ander bedrijf en de kans om bij een ander bedrijf te werken.

38 Omdat we alleen voor het oordeel over iemands employability en het risico op baanverlies significante verschillen in leergedrag vinden richten we ons in de analyses alleen op deze percepties. 
Het informeel leren buiten het werk, in de vorm van vrijwilligerswerk, mantelzorg, tijd met kinderen of zelfstudie vertoont geen verband voor iemands externe employability.
In Tabel 3.2 laten we de uitkomsten zien van de multivariate analyses om de mogelijke relaties tussen leren en externe employability in kaart te kunnen brengen. In deze analyse geeft het informeel leren van taken op het werk aan dat de respondent hoger scoort dan de mediane waarde voor informeel leren. Hierdoor kunnen we de coëfficiënt voor het informeel leren op het werk beter interpreteren en vergelijken met de coëfficiënt voor cursusdeelname. Het informeel leren buiten het werk, in de vorm van vrijwilligerswerk, mantelzorg, tijd met kinderen of zelfstudie (zie hoofdstuk 1), blijkt geen significant verband te vertonen met iemands externe employability. Deze coëfficiënten zijn dan ook niet weergegeven in Tabel 3.2.

Werkenden die een cursus hebben gevolgd hebben een positiever beeld van hun eigen externe employability. Een hoog percentage informeel leren op het werk speelt geen verklarende rol voor iemands externe employability als er gecontroleerd wordt voor achtergrondkenmerken.
Kolom 1 van Tabel 3.2 laat de ruwe correlaties tussen externe employability en cursus deelname en informeel leren zien, zonder dat rekening gehouden wordt met andere controlevariabelen. Voor zowel de cursusdeelname als het informeel leren van taken op het werk vinden we een significante positieve correlatie met iemands externe employ-

ability. Werkenden die de afgelopen twee jaar een cursus hebben gevolgd hebben een positiever oordeel over hun eigen externe employability. Werkenden hebben ook een positievere perceptie van hun eigen externe employability wanneer ze veel leren van het uitvoeren van de taken op het werk. In kolom 2 controleren we voor persoonskenmerken, bedrijfssector, ervaringsjaren in de huidige baan en diverse indicatoren voor iemands persoonlijkheid. Hieruit blijkt dat, ook wanneer gecontroleerd wordt voor deze factoren, er een positieve significante relatie is tussen iemands cursusdeelname en externe employability. Echter, de omvang van dit verband is gehalveerd ten opzichte van de relatie in kolom 1. De significante relatie tussen informeel leren op het werk en externe employability verdwijnt volledig. Dit blijkt niet te komen door de controle voor bedrijfssector, jaren in dienst of persoonlijkheid, maar is toe te schrijven aan de volgende persoonskenmerken: geslacht, leeftijd, opleidingsniveau, het al dan niet hebben van een partner en het aantal kinderen.

Grote organisatorische ontwikkelingen op het werk en sterke instabiliteit op de markt zorgen voor een slechtere perceptie van de werkenden over de eigen externe employability.
Kolom 3 van Tabel 3.2 laat de resultaten zien wanneer veranderingen op het werk en marktontwikkelingen als controlevariabele worden toegevoegd. Werkenden die geconfronteerd worden met grote organisato- 
rische ontwikkelingen op het werk schatten hun externe employability significant slechter in dan werkenden die niet geconfronteerd worden met organisatorische ontwikkelingen. Met betrekking tot de marktontwikkelingen waarop de organisatie van de werkende actief is, blijkt de instabiliteit van de afzetmarkt van de organisatie waar iemand werkzaam is sterk gecorreleerd met iemands externe employability: hoe hoger de instabiliteit op de afzetmarkt, hoe pessimistischer de werkende is over de eigen externe employability.

Om meer inzicht te krijgen in de rol van de cursusdeelname, gaan we in de laatste drie kolommen van Tabel 3.2 dieper in op enkele aspecten van de gevolgde cursussen. Allereerst kijken we in kolom 4 naar de bruikbaarheid van cursussen. In kolom 5 zoomen we in op de reden om een cursus te volgen en in kolom 6 kijken we naar de getrainde vaardigheden. De tabel laat zien dat werkenden die een cursus hebben gevolgd die zowel binnen als buiten het bedrijf relevant is een positiever beeld hebben van hun eigen externe employability dan werkenden die geen cursus hebben gevolgd. Alleen cursussen die zowel binnen als buiten het huidige bedrijf relevant zijn vergroten iemands externe employability. Verplichte cursussen dragen niet bij tot iemands externe employability, maar werkenden die een cursus gevolgd hebben om loopbaandoelen te realiseren hebben wel een positiever beeld van hun eigen externe employability dan werkenden die geen cursus hebben gevolgd. ${ }^{39}$ We vinden dezelfde positieve significante relatie voor een cursus die niet verplicht was. Voor wat betreft de vaardigheden waarop een cursus zich richt vinden we in kolom 6 alleen een significante positieve relatie tussen iemands externe employability en een cursus gericht op het verbeteren van iemands probleemoplossend vermogen. Fouarge (2017) laat zien dat dit ook een vaardigheid is die steeds belangrijk wordt op de arbeidsmarkt.

Informeel leren van de taken die men op het werk heeft is niet gerelateerd aan iemands externe employability.
Met betrekking tot informeel leren op het werk is ook gevraagd in welke mate wat geleerd is bruikbaar is voor de loopbaan binnen de huidige organisatie of andere organisaties binnen of buiten de eigen branche. Wij vinden echter geen significante relatie tussen de bruikbaarheid van het informeel leren voor iemands loopbaan en he beeld dat werkenden hebben van hun externe employability.

39 Aan personen die een cursus gevolgd hebben, is gevraagd is gevraagd naar de reden voor de gevolgde cursus. Verplichte cursussen en cursussen gericht op loopbaandoelen zijn de meest genoemde redenen (zie Hoofdstuk 1). Genoemde redenen sluiten echter elkaar niet uit. In de analyses wordt een onderscheid tussen geen cursus gevolgd, cursus gericht op de loopbaan, verplichten cursussen, cursussen die zowel gericht zijn op de loopbaan alsook met een verplichte karakter, en cursussen met andere redenen. 
TABEL 3.2 Informeel en formeel leren in relatie tot gepercipieerde externe employability, 2017

\begin{tabular}{|c|c|c|c|c|c|c|}
\hline & (1) & (2) & (3) & (4) & (5) & (6) \\
\hline Cursus in afgelopen 2 jaar & $0,232^{* * *}$ & $0,103^{* *}$ & $0,111^{* *}$ & & & \\
\hline $\begin{array}{l}\text { Percentage informeel leren van taken op het werk } \\
\text { gelijk aan of boven de mediaan }\end{array}$ & $0,304^{* * *}$ & 0,016 & 0,017 & 0,010 & 0,017 & 0,013 \\
\hline \multicolumn{7}{|c|}{ Technologische ontwikkelingen (ref: Geen ontwikkelingen) } \\
\hline Kleine ontwikkelingen & & & 0,052 & 0,055 & 0,054 & 0,049 \\
\hline Grote ontwikkelingen & & & 0,032 & 0,031 & 0,035 & 0,037 \\
\hline \multicolumn{7}{|c|}{ Organisatorische ontwikkelingen (ref: Geen ontwikkelingen) } \\
\hline Kleine ontwikkelingen & & & $-0,066$ & $-0,065$ & $-0,072$ & $-0,065$ \\
\hline Grote ontwikkelingen & & & $-0,152^{*}$ & $-0,153^{*}$ & $-0,159^{* *}$ & $-0,151^{*}$ \\
\hline \multicolumn{7}{|l|}{ Kenmerken van de markt } \\
\hline Sterke concurrentie op de markt & & & 0,077 & 0,075 & 0,081 & 0,080 \\
\hline Sterke instabiliteit op de markt & & & $-0,230^{* * *}$ & $-0,224^{* * *}$ & $-0,227^{* * *}$ & $-0,231^{* * *}$ \\
\hline \multicolumn{7}{|l|}{ Bruikbaarheid cursus (ref: Geen cursus gevolgd) } \\
\hline Bedrijfsspecifieke cursus gevolgd & & & & 0,108 & & \\
\hline $\begin{array}{l}\text { Gevolgde cursus relevant voor loopbaan buiten } \\
\text { bedrijf }\end{array}$ & & & & 0,150 & & \\
\hline $\begin{array}{l}\text { Gevolgde cursus relevant zowel binnen als } \\
\text { buiten bedrijf }\end{array}$ & & & & $0,143^{* *}$ & & \\
\hline Cursus niet bruikbaar binnen en buiten bedrijf & & & & $-0,023$ & & \\
\hline \multicolumn{7}{|l|}{ Reden voor volgen cursus (ref: Geen cursus gevolgd) } \\
\hline Om loopbaandoelen te realiseren & & & & & $0,189^{* *}$ & \\
\hline Verplichte cursus & & & & & 0,094 & \\
\hline $\begin{array}{l}\text { Zowel om loopbaandoelen te realiseren als } \\
\text { verplichte cursus }\end{array}$ & & & & & $-0,007$ & \\
\hline Andere soorten cursussen & & & & & $0,118^{*}$ & \\
\hline \multicolumn{7}{|l|}{ Getrainde vaardigheden (ref: Geen cursus gevolgd) } \\
\hline Samenwerken & & & & & & 0,183 \\
\hline Communicatie- en presentatievaardigheden & & & & & & 0,139 \\
\hline Fysieke conditie en kracht & & & & & & 0,189 \\
\hline Vaktechnische kennis en vermogen & & & & & & 0,088 \\
\hline Probleemoplossend vermogen & & & & & & $0,305^{* *}$ \\
\hline Time management & & & & & & 0,192 \\
\hline Informatieverwerking en administratie & & & & & & 0,057 \\
\hline Lees- en schrijfvaardigheid & & & & & & $-0,027$ \\
\hline Cijfermatig inzicht & & & & & & $-0,397$ \\
\hline Digitale vaardigheden & & & & & & 0,216 \\
\hline Persoonlijke ontwikkeling & & & & & & 0,033 \\
\hline Leidinggeven en coaching & & & & & & 0,153 \\
\hline Constant & $2,484^{* * *}$ & $3,332^{* * *}$ & $3,353^{* * *}$ & $3,352^{* * *}$ & $3,348^{* * *}$ & $3,351^{* * *}$ \\
\hline Controle variabelen & nee & ja & ja & ja & ja & ja \\
\hline N & 2.279 & 2.200 & 2.200 & 2.200 & 2.200 & 2.200 \\
\hline R-kwadraat & 0,023 & 0,270 & 0,276 & 0,278 & 0,277 & 0,279 \\
\hline
\end{tabular}

${ }^{* * *} p<0,01,{ }^{* *} p<0,05,{ }^{*} p<0,1$

Bron: ROA LLL enquête, 2017

Overige controlevariabelen: persoonlijkheid, risico- en tijdsvoorkeur, bedrijfssector, aantal jaren ervaring, geslacht, leeftijd, opleidingsniveau, het al dan niet hebben van een partner en het aantal kinderen 


\section{Leren en het risico op baanverlies}

Tabel 3.3 laat de resultaten zien van vergelijkbare analyses voor de relatie tussen het leren en het risico op baanverlies. De interpretatie van de coëfficiënten met betrekking tot de duurzame inzetbaarheid verschilt echter wel van die in Tabel 3.2. In Tabel 3.2 geeft een positieve coëfficiënt namelijk een stijging in de externe employability aan. Een positieve coëfficiënt in Tabel 3.3 geeft juist een negatief beeld met betrekking tot de duurzame inzetbaarheid. Dit houdt namelijk in dat de werkenden een hogere kans ervaren om hun baan te verliezen.

Werkenden schatten het risico om hun baan te verliezen significant lager in als ze een cursus hebben gevolgd. Ook werkenden die relatief gezien veel leren van het uitvoeren van taken op het werk schatten de kans op baanverlies lager in. Dit laatste is echter geheel toe te schrijven aan enkele persoonskenmerken
Voor zowel de cursusdeelname als voor het informeel leren van de taken die men op het werk uitvoert vinden we in kolom 1 significante correlaties met het risico op baanverlies. Degenen die in de afgelopen 2 jaar een cursus hebben gevolgd ervaren een kleiner risico op baanverlies. Ook werkenden die relatief gezien veel leren van het uitvoeren van taken op het werk schatten de kans op

baanverlies lager in. Dit suggereert dat het blijven leren bijdraagt aan iemands baanzekerheid. Om deze relaties verder te testen controleren we in kolom 2 voor dezelfde achtergrondkenmerken als in Tabel 3.2. De coëfficiënt met betrekking tot de cursusdeelname blijft negatief en significant. Echter zien we, net zoals in Tabel 3.2, dat wanneer we controlevariabelen toevoegen aan de analyses de significante relatie tussen het informeel leren van de taken op het werk en het risico op baanverlies verdwijnt. De persoonskenmerken (zoals geslacht, leeftijd, opleidingsniveau) blijken ervoor te zorgen dat de correlatie insignificant wordt.

Technologische ontwikkelingen op het werk verlagen het geschatte risico op baanverlies terwijl organisatorische ontwikkelingen deze juist verhogen. Daarnaast zorgt een onzekerdere markt waarop de organisatie actief is ook voor een hogere schatting van het risico op baanverlies.
Wanneer we vervolgens in kolom 3 controleren voor de ontwikkelingen op het werk en de kenmerken van de afzetmarkt waarop het bedrijf opereert, dan zien we dat de coëfficiënt voor informeel leren van taken op het werk zwak significant is. Ook zien we dat hoe groter de technologische ontwikkelingen zijn hoe lager de werkenden het risico inschatten

om hun baan te verliezen. Dit suggereert dat werkenden die in een technologisch dynamische organisatie werkzaam zijn juist een sterke arbeidsmarktpositie opbouwen. Dit is in lijn met de bevindingen van Bartel \& Sicherman (1993), die laten zien dat werkenden die geconfronteerd worden met continue technologische veranderingen later met pensioen gaan, en Allen \& De Grip (2012), die laten zien dat werkenden die scholingsveroudering ervaren door technologische veranderingen een grotere kans hebben om te blijven 
werken. In beide studies wordt het positieve effect van technologische ontwikkelingen op baanbehoud verklaard vanuit het feit dat werkenden hun competenties telkens updaten.

Waar technologische ontwikkelingen zorgen voor een positiever beeld over baanzekerheid zien we het tegenovergestelde voor organisatorische ontwikkelingen. Werkenden die te maken hebben met organisatorische ontwikkelingen op het werk schatten het risico dat zij hun baan verliezen hoger in dan werkenden die geconfronteerd worden met deze ontwikkelingen. Een mogelijke verklaring hiervoor is dat reorganisaties binnen het bedrijven voor onzekerheid zorgen onder het personeel. Dit kan werkenden meer pessimistisch maken over hun baanzekerheid. Ook zien we dat hoe onzekerder de afzetmarkt waarop het bedrijf waar iemand werkt actief is, in termen van concurrentie en instabiliteit, hoe hoger de werkenden de kans inschatten dat ze hun baan zullen verliezen.

Het maakt het niet uit wat voor cursus er gevolgd is, vergeleken met werkenden die geen cursus wordt het risico op baanverlies lager ingeschat. De enige uitzondering is een cursus die enkel relevant is voor een loopbaan buiten het bedrijf, dan is het risico op baanverlies wel hoger.
Net zoals in Tabel 3.2 zoomen we in de laatste drie kolommen van Tabel 3.3 in op verschillende aspecten van de cursussen. Werkenden die een cursus hebben gevolgd die alleen buiten het bedrijf bruikbaar was schatten de kans om hun baan te verliezen hoger in dan werkenden die geen cursus hebben gevolgd. Mogelijk heeft dit te maken met de toepas-

baarheid van de cursus: als de opgedane kennis en vaardigheden van een dergelijke cursus niet toe te passen zijn in het bedrijf waarin iemand werkzaam is dan zou dat de baanzekerheid in gevaar kunnen brengen. Een andere mogelijke verklaring is dat het aanbieden van een cursus die alleen bedoeld is om de externe employability te verhogen, vaker gebeurd als de werkgever anticipeert op het risico dat iemand zijn of haar baan dreigt te verliezen..$^{\circ}$ Wanneer de opgedane kennis zowel binnen als buiten het bedrijf bruikbaar is ervaren werkenden een lager risico om hun baan te verliezen. Hoewel niet alle redenen om een cursus te volgen en alle getrainde vaardigheden geen significante relatie hebben met het risico op baanverlies, wijzen alle coëfficiënten in dezelfde richting: een verminderde kans op baanverlies.

Wij hebben ook bekeken in welke mate de bruikbaarheid van het informeel leren van iemands taken op het werk gerelateerd is aan het risico op baanverlies. Uit de analyses blijkt dat werkenden voor wie de opgedane kennis nauwelijks bruikbaar is in hun huidige werk het risico op baanverlies significant hoger inschatten. Hierbij moet echter vermeld worden dat deze groep zeer klein is. significant mede doordat het geschat wordt op een beperkt aantal respondenten. 
TABEL 3.3 Informeel en formeel leren in relatie tot het gepercipieerde risico op baanverlies, 2017

\begin{tabular}{|c|c|c|c|c|c|c|}
\hline & (1) & $(2)$ & (3) & (4) & $(5)$ & (6) \\
\hline Cursus in afgelopen 2 jaar & $-0,175^{* * *}$ & $-0,109^{* *}$ & $-0,133^{* * *}$ & & & \\
\hline $\begin{array}{l}\text { Percentage informeel leren van taken op } \\
\text { het werk gelijk aan of boven de mediaan }\end{array}$ & $-0,093^{*}$ & $-0,078$ & $-0,089^{*}$ & $-0,077$ & $-0,088^{*}$ & $-0,088^{*}$ \\
\hline \multicolumn{7}{|c|}{ Technologische ontwikkelingen (ref: Geen ontwikkelingen) } \\
\hline Kleine ontwikkelingen & & & $-0,140^{* *}$ & $-0,135^{* *}$ & $-0,140^{* *}$ & $-0,130^{*}$ \\
\hline Grote ontwikkelingen & & & $-0,196^{* * *}$ & $-0,178^{* *}$ & $-0,197^{* * *}$ & $-0,183^{* *}$ \\
\hline \multicolumn{7}{|c|}{ Organisatorische ontwikkelingen (ref: Geen ontwikkelingen) } \\
\hline Kleine ontwikkelingen & & & $0,199 * * *$ & $0,187^{* * *}$ & $0,199^{* * *}$ & $0,194^{* * *}$ \\
\hline Grote ontwikkelingen & & & $0,459^{* * *}$ & $0,450^{* * *}$ & $0,460^{* * *}$ & $0,455^{* * *}$ \\
\hline \multicolumn{7}{|l|}{ Kenmerken van de markt } \\
\hline Sterke concurrentie op de markt & & & $0,220^{* * *}$ & $0,232^{* * *}$ & $0,221^{* * *}$ & $0,226^{* * *}$ \\
\hline Sterke instabiliteit op de markt & & & $0,163^{* * *}$ & $0,147^{* *}$ & $0,162^{* * *}$ & $0,162^{* * *}$ \\
\hline \multicolumn{7}{|c|}{ Bruikbaarheid cursus (ref: Geen cursus gevolgd) } \\
\hline Bedrijfsspecifieke cursus gevolgd & & & & $-0,134$ & & \\
\hline $\begin{array}{l}\text { Gevolgde cursus relevant voor loopbaan } \\
\text { buiten bedrijf }\end{array}$ & & & & $0,222^{*}$ & & \\
\hline $\begin{array}{l}\text { Gevolgde cursus relevant zowel binnen } \\
\text { als buiten bedrijf }\end{array}$ & & & & $-0,233^{* * *}$ & & \\
\hline $\begin{array}{l}\text { Cursus niet bruikbaar binnen en buiten } \\
\text { bedrijf }\end{array}$ & & & & 0,118 & & \\
\hline \multicolumn{7}{|c|}{ Reden voor volgen cursus (ref: Geen cursus gevolgd) } \\
\hline Om loopbaandoelen te realiseren & & & & & $-0,139^{*}$ & \\
\hline Verplichte cursus & & & & & $-0,092$ & \\
\hline $\begin{array}{l}\text { Zowel om loopbaandoelen te realiseren } \\
\text { als verplichte cursus }\end{array}$ & & & & & $-0,171^{*}$ & \\
\hline Andere soorten cursussen & & & & & $-0,153^{* *}$ & \\
\hline \multicolumn{7}{|c|}{ Getrainde vaardigheden (ref: Geen cursus gevolgd) } \\
\hline Samenwerken & & & & & & $-0,069$ \\
\hline $\begin{array}{l}\text { Communicatie- en } \\
\text { presentatievaardigheden }\end{array}$ & & & & & & $-0,062$ \\
\hline Fysieke conditie en kracht & & & & & & $-0,016$ \\
\hline Vaktechnische kennis en vermogen & & & & & & $-0,202^{* * *}$ \\
\hline Probleemoplossend vermogen & & & & & & 0,188 \\
\hline Time management & & & & & & $-0,464^{* *}$ \\
\hline Informatieverwerking en administratie & & & & & & $-0,072$ \\
\hline Lees- en schrijfvaardigheid & & & & & & $-0,308$ \\
\hline Cijfermatig inzicht & & & & & & $-0,037$ \\
\hline Digitale vaardigheden & & & & & & $-0,190$ \\
\hline Persoonlijke ontwikkeling & & & & & & $-0,036$ \\
\hline Leidinggeven en coaching & & & & & & $-0,074$ \\
\hline Constant & $2,267^{* * *}$ & $2,672^{* * *}$ & $2,460^{* * *}$ & $2,453^{* * *}$ & $2,459^{* * *}$ & $2,436^{* * *}$ \\
\hline Controle variabelen & nee & ja & ja & ja & ja & ja \\
\hline N & 2,279 & 2,200 & 2,200 & 2,200 & 2,200 & 2,200 \\
\hline R-kwadraat & 0,008 & 0,112 & 0,142 & 0,152 & 0,143 & 0,148 \\
\hline
\end{tabular}

${ }^{* * *} \mathrm{p}<0.01,{ }^{* *} \mathrm{p}<0.05{ }^{*} \mathrm{p}<0.1$

Bron: ROA LLL enquête, 2017

Overige controles: persoonlijkheid, risico- en tijdsvoorkeur, sector van activiteit, aantal jaren ervaring, geslacht, leeftijd, opleidingsniveau, het al dan niet hebben van een partner en het aantal kinderen. 


\section{Leren en de verwachte pensioenleeftijd}

De leeftijd waarop iemand met pensioen verwacht te gaan, geeft ook een indicatie van de verwachte inzetbaarheid op de arbeidsmarkt. Vanuit dat perspectief onderzoeken we de relatie tussen de verwachte pensioenleeftijd en iemands cursusparticipatie en informele leren op het werk. Om deze analyses uit te kunnen voeren koppelen we de verwachte pensioenleeftijd vanuit het LISS panel aan de ROA Levenslang Leren Enquête 2017. De verwachte pensioenleeftijd is gebaseerd op de vraag "Op welke leeftijd verwacht u te stoppen met werken?" Deze vraag is alleen gesteld aan werkenden ouder dan 44 jaar. Om die reden is het aantal observaties kleiner dan bij de eerdere analyses.

Tabel 3.4 geeft een overzicht van de leeftijd waarop de respondenten met pensioen verwachten te gaan. 35 procent van de werkenden verwacht op 67 jarige leeftijd met pensioen te gaan. Anderen verwachten een pensioenleeftijd die dicht tegen de 67 aan ligt. 19 procent van de werkenden verwacht voordat men 65 wordt met pensioen te gaan. Bij de verwachte pensioenleeftijd maakt het overigens niet uit hoe oud de respondent op dit moment is.

TABEL 3.4 Verwachte pensioenleeftijd van werkenden, 2017

\begin{tabular}{|l|l|l|}
\hline Verwachte pensioensleeftijd & Frequentie & Percentage \\
\hline Lager dan 65 & 172 & $19 \%$ \\
\hline 65 & 146 & $16 \%$ \\
\hline 66 & 70 & $8 \%$ \\
\hline 67 & 317 & $35 \%$ \\
\hline 68 & 112 & $12 \%$ \\
\hline 69 & 29 & $3 \%$ \\
\hline Hoger dan 69 & 60 & $7 \%$ \\
\hline Totaal & 906 & $100 \%$ \\
\hline
\end{tabular}

Bron: LISS 2017

Werkenden die een cursus hebben gevolgd verwachten een halfjaar later met pensioen te gaan dan werkenden die geen cursus hebben gevolgd.
Tabel 3.5 laat zien dat dat werkenden die een cursus hebben gevolgd verwachten ongeveer een half jaar later met pensioen te gaan (zie kolom 2). Dit kan erop duiden dat werkenden die een cursus hebben gevolgd

het idee hebben er nog even tegen aan te kunnen gaan. Maar het is ook mogelijk dat werkenden die aangeven langer te willen werken vaker een cursus aangeboden krijgen van hun werkgever.

Informeel leren is niet significant gerelateerd aan de verwachte pensioenleeftijd. Dat geldt ook voor de ontwikkelingen op het werk en de kenmerken van de markt waarop de organisatie waar iemand werkt actief is. 
TABEL 3.5 Informeel en formeel leren in relatie tot de verwachte pensioenleeftijd, 2017

\begin{tabular}{|c|c|c|c|c|c|c|}
\hline & (1) & (2) & (3) & (4) & (5) & (6) \\
\hline Cursus in afgelopen 2 jaar & 0,324 & $0,505^{* *}$ & $0,454^{* *}$ & & & \\
\hline $\begin{array}{l}\text { Percentage informeel leren van taken op het } \\
\text { werk gelijk aan of boven de mediaan }\end{array}$ & 0,291 & 0,355 & 0,298 & 0,290 & 0,309 & 0,316 \\
\hline \multicolumn{7}{|c|}{ Technologische ontwikkelingen (ref: Geen ontwikkelingen) } \\
\hline Kleine ontwikkelingen & & & $-0,100$ & $-0,105$ & $-0,074$ & $-0,027$ \\
\hline Grote ontwikkelingen & & & 0,207 & 0,212 & 0,212 & 0,233 \\
\hline \multicolumn{7}{|c|}{ Organisatorische ontwikkelingen (ref: Geen ontwikkelingen) } \\
\hline Kleine ontwikkelingen & & & 0,404 & 0,407 & 0,381 & 0,362 \\
\hline Grote ontwikkelingen & & & 0,532 & 0,540 & 0,490 & 0,468 \\
\hline \multicolumn{7}{|l|}{ Kenmerken van de markt } \\
\hline Sterke concurrentie op de markt & & & 0,167 & 0,166 & 0,204 & 0,169 \\
\hline Sterke instabiliteit op de markt & & & $-0,265$ & $-0,265$ & $-0,249$ & $-0,267$ \\
\hline \multicolumn{7}{|l|}{ Bruikbaarheid cursus (ref: Geen cursus gevolgd) } \\
\hline Bedrijfsspecifieke cursus gevolgd & & & & 0,241 & & \\
\hline $\begin{array}{l}\text { Gevolgde cursus relevant voor loopbaan } \\
\text { buiten bedrijf }\end{array}$ & & & & 1,089 & & \\
\hline $\begin{array}{l}\text { Gevolgde cursus relevant zowel binnen als } \\
\text { buiten bedrijf }\end{array}$ & & & & $0,458^{*}$ & & \\
\hline Cursus niet bruikbaar binnen en buiten bedrijf & & & & 0,478 & & \\
\hline \multicolumn{7}{|c|}{ Reden voor volgen cursus (ref: Geen cursus gevolgd) } \\
\hline Om loopbaandoelen te realiseren & & & & & $0,808^{*}$ & \\
\hline Verplichte cursus & & & & & 0,164 & \\
\hline $\begin{array}{l}\text { Zowel om loopbaandoelen te realiseren als } \\
\text { verplichte cursus }\end{array}$ & & & & & $-0,192$ & \\
\hline Andere soorten cursussen & & & & & $0,775^{* * *}$ & \\
\hline \multicolumn{7}{|l|}{ Getrainde vaardigheden (ref: Geen cursus gevolgd) } \\
\hline Samenwerken & & & & & & 0,161 \\
\hline Communicatie- en presentatievaardigheden & & & & & & 0,296 \\
\hline Fysieke conditie en kracht & & & & & & $-2,385$ \\
\hline Vaktechnische kennis en vermogen & & & & & & $0,469^{*}$ \\
\hline Probleemoplossend vermogen & & & & & & 0,358 \\
\hline Time management & & & & & & 0,616 \\
\hline Informatieverwerking en administratie & & & & & & 0,581 \\
\hline Lees- en schrijfvaardigheid & & & & & & 0,121 \\
\hline Cijfermatig inzicht & & & & & & 1,788 \\
\hline Digitale vaardigheden & & & & & & $1,898^{* *}$ \\
\hline Persoonlijke ontwikkeling & & & & & & 0,443 \\
\hline Leidinggeven en coaching & & & & & & 0,254 \\
\hline Constant & $65,711^{* * *}$ & $67,302^{* * *}$ & $66,780^{* * *}$ & $66,722^{* * *}$ & $66,655^{* * *}$ & $66,716^{* * *}$ \\
\hline Controle variabelen & nee & ja & ja & ja & ja & ja \\
\hline N & 904 & 889 & 889 & 889 & 889 & 889 \\
\hline R-kwadraat & 0,005 & 0,089 & 0,096 & 0,097 & 0,103 & 0,104 \\
\hline
\end{tabular}

*** $p<0.01,{ }^{* *} p<0.05,{ }^{*} p<0.1$

Bron: ROA LLL enquête \& LISS, 2017

Overige controles: persoonlijkheid, risico- en tijdsvoorkeur, sector van activiteit, aantal jaren ervaring, geslacht, leeftijd, opleidingsniveau, het al dan niet hebben van een partner en het aantal kinderen. 
De hogere verwachte pensioenleeftijd wordt gedreven door cursussen die zowel binnen als buiten het bedrijf bruikbaar zijn, gevolgd zijn om loopbaandoelen te realiseren of gericht op vaktechnische kennis en vermogen of digitale vaardigheden.
Om meer inzicht te krijgen in de verklarende rol van cursussen zoomen we net als bij de analyses van iemands externe employability en risico op baanverlies in op de kenmerken van de gevolgde cursus. Zo zien we dat werkenden die een cursus die zowel binnen als buiten het huidige bedrijf bruikbaar is hebben gevolgd hun pensioenleeftijd significant hoger inschatten dan werkenden die geen cursus hebben gevolgd. Ook het volgen van cursussen met andere redenen dan verplichte cursussen of cursussen gericht op de loopbaan leidt tot een hogere verwachte pensioenleeftijd. Tot slot zien we ook een hogere verwachte pensioenleeftijd onder werkenden die een cursus hebben gevolgd gericht op vaktechnische kennis en vermogen of digitale vaardigheden. 


\section{LITERATUUR}

Allen, J., Grip, A. de (2012). Does skill obsolescence increase the risk of employment loss? Applied Economics, 44 (25), 3237-3245.

Bapna, R., Langer, N., Mehra, A., Gopal, R., \& Gupta, A. (2013). Human capital investments and employee performance: an analysis of IT services industry. Management Science, 59(3), 641-658.

Bartel, A.P.,Sicherman, N. (1993) Technological change and retirement decisions of older workers, Journal of Labor Economics, 11(1), 162-183.

Becker, G. (1964). Human capital. Chicago: University of Chicago Press.

Berge, W. van den, \& Weel, B. ter (2015). Baanpolarisatie in Nederland. CPB Policy Brief 2015/13

Bijlsma, I., Dijksman, S., Fouarge, D., \& Künn-Nelen, A. (2015). Winnaars en verliezers op de arbeidsmarkt 1996-2012. Tijdschrift voor Arbeidsvraagstukken, 31(2), 106-123.

Borghans, L., Fouarge, D., \& Grip, A. de (2011). Een leven lang leren in Nederland. Maastricht: ROA-R$2011 / 5$.

Borghans, L., Golsteyn, B., \& Grip, A. de (2006). Meer werken is meer leren. Determinanten van kennisontwikkeling, 's-Hertogenbosch: CINOP.

Borghans, L., Golsteyn, B., \& Grip, A. de (2007). Werkend leren, Economische Statistische Berichten, 92(4509), 260-263.

Borghans, L., Weel, B. ter, \& Weinberg, B. A. (2008). Interpersonal styles and labor market outcomes. Journal of Human Resources, 43(4), 815-858.

Büyükkeçeci, Z., Fouarge, D., \& Grip, A. de (2017). Why do some workers never participate in training? Maastricht, mimeo.

Dearden, L., Reed, H. \& Reenen, J. van (2006). The impact of training on productivity and wages: evidence from Britisch panel data, Oxford Bulletin of Economics and Statistics, 68(4), 397-421.

Dekker, R., Fouarge, D., \& Schils, T. (2008). Concurrentie tussen arbeidsmarkt- en maatschappelijke participatie. ESB, 93(4538): 404-407.

Fouarge, D. (2018). Veel werkenden laten zich bijscholen. ESB.

Fouarge, D. (2017). Veranderingen in werk en vaardigheden. Oratie, Maastricht University.

Fouarge, D., \& Grip, A. de (2014). Gaan 50-plussers meer investeren in hun scholing? Tilburg University, Netspar, NEA paper 54.

Fouarge, D., Grip, A. de, Smits, W., \& Vries, R. de (2012). Flexible contracts and human capital investments, The Economist, 160(2), 177-195.

Fouarge, D., Schils, T., \& Grip, A. de (2013). Why Do Low-Educated Workers Invest Less in Further Training? Applied Economics, 45(18): 2587-2601. 
Graaf-Zijl, M. de, Horst, A. van der \& Vuuren, D. van (2015). Langdurige Werkloosheid: Afwachten én Hervormen, CPB Policy Brief 2015/11.

Grip, A. de, \& Sauermann, J. (2012). The effects of training on own and co-worker productivity: evidence from a field experiment, The Economic Journal, 122(559), 376-399.

Groot, W., \& De Brink, H. M. V. (2000). Education, training and employability. Applied Economics, 32(5), 573-581.

Künn-Nelen, A., Eldert, P. van, Fouarge, D., Grip, A. de, \& Poulissen, D. (2018). Leren onder werkenden met een kwetsbare positie op de arbeidsmarkt. Maastricht: ROA-R-2018/5.

ROA (2017). De arbeidsmarkt naar opleiding en beroep tot 2022. Maastricht: ROA-R-2017/10.

Weel, B. ter, \& Kok, S. (2013). De Nederlandse arbeidsmarkt in taken. Eerste bevindingen uit de Nederlandse Skills Survey. CPB: The Hague. 


\section{BIJLAGE A}

De dataverzameling voor ROA Levenslang Leren Enquête 2004, 2007, 2010 en 2013 heeft telkens plaatsgevonden in het najaar, waarbij gebruik is gemaakt van het CentERpanel. Dit is een panel van ruim 2.000 huishoudens die iedere week een vragenlijst invullen via Internet. De gegevens zijn op individueel niveau koppelbaar aan de DNB Household Survey (DHS). In februari 2017 vond de vijfde meting van de ROA Levenslang Leren Enquête plaats. Ditmaal onder respondenten van het LISS panel. Hier is om twee redenen voor gekozen. Ten eerste is het LISS panel groter. Ten tweede kunnen de data hierdoor worden gekoppeld aan de Nederlandse Skills Survey dat ook is afgenomen onder respondenten van het LISS panel. Tabel A.1 geeft een overzicht van de samenstelling van de steekproeven. De data zijn, na weging, representatief voor de potentiële beroepsbevolking.

In verband met de vergelijkbaarheid over de jaren is de vraagstelling voor de kernvariabelen in de surveys onveranderd gebleven (zie Tabel A.2). In Tabel A.3 geven wij een beschrijving van het percentage respondenten dat een cursus heeft gevolgd in de afgelopen twee jaar, het percentage informeel leren van taken op het werk, en de kennisontwikkeling voor respondenten tot 67 jaar (gehele steekproef, werkenden en niet-werkenden). De definitie van werkenden gaat uit van de belangrijkste bezigheid van respondenten in de leeftijd 16-67 jaar, ongeacht het aantal gewerkte uren: 1) betaald werk in loondienst, 2) werkzaam of meewerkend in een gezins- of familiebedrijf 3) vrije beroepsbeoefenaar, freelancer of zelfstandige. Niet-werkenden zijn personen die niet onder een van deze drie categorieën vallen.

De Nederlandse Skills Survey (NSS) is in 2012 en 2017 afgenomen onder deelnemers aan het LISS panel en wordt gebruikt voor de analyses in hoofdstuk 2. De NSS, is afgeleid van de British Skills Survey en heeft als doel de taken en vaardigheden van Nederlandse beroepsbevolking in kaart te brengen (Ter Weel en Kok, 2013). Bij de dataverzameling in 2017 is er voor gezorgd dat deelnemers aan de ROA Levenslang Leren Enquête 2017 benaderd zijn voor deelname aan de NSS waardoor iemands taken op individueel niveau gelinkt kunnen worden aan leeractiviteiten. Tabel A.4 geeft een overzicht van de in de NSS gemeten taken. 
TABEL A.1 Samenstelling van de steekproef (ongewogen aantallen)

\begin{tabular}{|c|c|c|c|c|c|}
\hline & 2004 & 2007 & 2010 & 2013 & 2017 \\
\hline Totaal & 2.376 & 1.776 & 1.974 & 1.992 & 4.791 \\
\hline \multicolumn{6}{|l|}{ Geslacht } \\
\hline man & 1.244 & 938 & 1.055 & 1.040 & 2.215 \\
\hline vrouw & 1.132 & 838 & 919 & 952 & 2.576 \\
\hline \multicolumn{6}{|l|}{ Leeftijd } \\
\hline $16-24$ & 159 & 90 & 82 & 61 & 487 \\
\hline $25-34$ & 402 & 249 & 155 & 261 & 591 \\
\hline $35-44$ & 473 & 305 & 334 & 304 & 709 \\
\hline $45-54$ & 528 & 385 & 373 & 313 & 918 \\
\hline $55-66$ & 477 & 427 & 603 & 549 & 1.251 \\
\hline $67+$ & 336 & 320 & 427 & 504 & 835 \\
\hline \multicolumn{6}{|l|}{ Opleidingsniveau ${ }^{1)}$} \\
\hline basisonderwijs & 139 & 94 & 104 & 80 & 364 \\
\hline vmbo & 633 & 492 & 534 & 474 & 957 \\
\hline havo/vwo & 311 & 229 & 230 & 224 & 540 \\
\hline mbo & 463 & 345 & 330 & 335 & 1.188 \\
\hline hbo & 564 & 415 & 518 & 567 & 1.188 \\
\hline wo & 263 & 197 & 254 & 311 & 546 \\
\hline \multicolumn{6}{|l|}{ Arbeidsmarktstatus } \\
\hline verricht betaald werk in loondienst & 1.197 & 872 & 900 & 916 & 2.281 \\
\hline werkt of is meewerkend in gezins- of familiebedrijf & 15 & 7 & 10 & 11 & 49 \\
\hline is vrije beroepsbeoefenaar, freelance of zelfstandige & 78 & 62 & 101 & 82 & 232 \\
\hline zoekt werk na verlies werkkring & 48 & 24 & 36 & 54 & 128 \\
\hline zoekt voor het eerst werk & 4 & 4 & 4 & 5 & 14 \\
\hline gaat naar school of studeert & 141 & 76 & 64 & 52 & 429 \\
\hline verzorgt de huishouding & 312 & 225 & 198 & 173 & 326 \\
\hline is met pensioen (vervroegd, aow of vut) & 406 & 381 & 521 & 548 & 925 \\
\hline is (gedeeltelijk) arbeidsongeschikt & 107 & 79 & 86 & 67 & 208 \\
\hline verricht onbetaald werk met behoud van uitkering & 3 & 1 & 4 & 4 & 20 \\
\hline verricht vrijwilligerswerk & 42 & 32 & 37 & 69 & 130 \\
\hline doet iets anders & 22 & 13 & 13 & 10 & 42 \\
\hline is te jong, heeft nog geen bezigheden & . & . & . & 1 & 7 \\
\hline
\end{tabular}

1) In het rapport wordt ook wel verwezen naar laagopgeleiden (basisonderwijs of vmbo), middelbaar opgeleiden (mbo of havo/vwo) en hoogopgeleiden (hbo of wo). 
TABEL A.2 Meting van een aantal kernvariabelen in de ROA Levenslang Leren Enquête

\begin{tabular}{|l|l|}
\hline Variabele & Vraag \\
\hline Deelname aan cursussen en trainingen & $\begin{array}{l}\text { Hoeveel cursussen en/of trainingen hebt u in de afgelopen twee jaar afgerond? Laat } \\
\text { pure hobby-cursussen (bridge, schilderen) buiten beschouwing. Cursussen die u als } \\
\text { hobby ziet, maar voor anderen nuttig kunnen zijn voor het werk tellen wel mee. }\end{array}$ \\
\hline Informeel leren op het werk & Hoeveel procent van de werktijd besteedt u aan taken waarvan u kunt leren? \\
\hline Leren van vrijwilligerswerk & $\begin{array}{l}\text { Eerder hebt u aangegeven dat u tijd besteedt aan vrijwilligerswerk. } \\
\text { Hoeveel procent van deze tijd besteedt u aan taken waarvan u kunt leren? }\end{array}$ \\
\hline Leren van mantelzorg & $\begin{array}{l}\text { Eerder hebt u aangegeven dat u tijd besteedt aan mantelzorg. } \\
\text { Hoeveel procent van deze tijd besteedt u aan taken waarvan u kunt leren? }\end{array}$ \\
\hline Leren van tijd met kinderen & $\begin{array}{l}\text { Eerder hebt u aangegeven dat u tijd besteedt met kinderen. } \\
\text { Hoeveel procent van deze tijd besteedt u aan taken waarvan u kunt leren? }\end{array}$ \\
\hline Kennisontwikkeling & $\begin{array}{l}\text { Stelt u zich voor welke kennis en vaardigheden nodig zijn voor uw werk om in uw ogen } \\
\text { optimaal te kunnen functioneren. Als dit ideaal gelijk is aan 100, hoe hoog schat u dan } \\
\text { uw vaardigheden in: } \\
\text { Twee jaar geleden? } \\
\text { Op dit moment? } \\
\text { De kennisontwikkeling wordt gemeten als het verschil tussen de twee antwoorden. }\end{array}$ \\
\hline Hoe groot schat u de kans dat, als u nu op zoek zou moeten gaan naar een andere \\
baan, u een baan zou kunnen krijgen van vergelijkbaar niveau als uw huidige baan?
\end{tabular}


TABEL A.3 Cursusdeelname, informeel leren van taken op het werk en kennisontwikkeling naar geslacht, leeftijdscategorie en opleidingsniveau, 2017 (percentages)

\begin{tabular}{|c|c|c|c|}
\hline & Cursusdeelname & $\begin{array}{l}\text { Informeel leren van taken } \\
\text { op het werk }\end{array}$ & Kennisontwikkeling \\
\hline Totaal & 42 & 25 & 9 \\
\hline \multicolumn{4}{|l|}{ Geslacht } \\
\hline $\operatorname{man}$ & 45 & 24 & 9 \\
\hline vrouw & 38 & 26 & 9 \\
\hline \multicolumn{4}{|l|}{ Leeftijd } \\
\hline $16-24$ & 31 & 32 & 24 \\
\hline $25-34$ & 50 & 28 & 11 \\
\hline $35-44$ & 53 & 23 & 7 \\
\hline $45-54$ & 46 & 22 & 5 \\
\hline $55-66$ & 33 & 19 & -1 \\
\hline \multicolumn{4}{|l|}{ Opleidingsniveau } \\
\hline basisonderwijs & 26 & 31 & 20 \\
\hline vmbo & 29 & 20 & 5 \\
\hline havo/vwo & 34 & 27 & 14 \\
\hline mbo & 44 & 22 & 6 \\
\hline hbo & 55 & 26 & 7 \\
\hline wo & 62 & 32 & 9 \\
\hline Totaal werkenden & 54 & 24 & 9 \\
\hline \multicolumn{4}{|l|}{ Geslacht } \\
\hline $\operatorname{man}$ & 54 & 24 & 9 \\
\hline vrouw & 54 & 24 & 9 \\
\hline \multicolumn{4}{|l|}{ Leeftijd } \\
\hline $16-24$ & 47 & 33 & 25 \\
\hline $25-34$ & 57 & 27 & 12 \\
\hline $35-44$ & 57 & 23 & 8 \\
\hline $45-54$ & 53 & 22 & 7 \\
\hline $55-66$ & 50 & 20 & 4 \\
\hline \multicolumn{4}{|l|}{ Opleidingsniveau } \\
\hline basisonderwijs & 42 & 31 & 15 \\
\hline vmbo & 38 & 18 & 7 \\
\hline havo/vwo & 47 & 25 & 10 \\
\hline mbo & 54 & 21 & 9 \\
\hline hbo & 62 & 25 & 8 \\
\hline wo & 65 & 32 & 9 \\
\hline Totaal niet-werkenden & 23 & 30 & 10 \\
\hline \multicolumn{4}{|l|}{ Geslacht } \\
\hline $\operatorname{man}$ & 27 & 27 & 10 \\
\hline vrouw & 20 & 32 & 9 \\
\hline \multicolumn{4}{|l|}{ Leeftijd } \\
\hline $16-24$ & 27 & 32 & 24 \\
\hline $25-34$ & 28 & 36 & 9 \\
\hline $35-44$ & 28 & 34 & 3 \\
\hline $45-54$ & 22 & 18 & -1 \\
\hline $55-66$ & 15 & 11 & -6 \\
\hline \multicolumn{4}{|l|}{ Opleidingsniveau } \\
\hline basisonderwijs & 21 & 31 & 21 \\
\hline vmbo & 19 & 30 & 3 \\
\hline havo/vwo & 26 & 29 & 16 \\
\hline mbo & 18 & 28 & 0 \\
\hline hbo & 30 & 30 & 3 \\
\hline wo & 44 & 34 & 6 \\
\hline
\end{tabular}


TABEL A.4 Taken NSS per geaggregeerde groep

\begin{tabular}{|c|c|}
\hline Groep & Taak \\
\hline \multirow[t]{9}{*}{ Interpersoonlijke vaardigheden } & omgaan met mensen \\
\hline & samen werken in een team met anderen \\
\hline & goed luisteren naar collega's \\
\hline & het geven van feedback aan collega's's) \\
\hline & het instrueren, trainen of iets leren aan anderen \\
\hline & het houden van presentaties \\
\hline & het verkopen van een product of dienst \\
\hline & het overtuigen en beïnvloeden van anderen \\
\hline & het adviseren en begeleiden van klanten of cliënten \\
\hline \multirow[t]{3}{*}{ Rekenvaardigheden } & optellen, aftrekken, vermenigvuldigen en delen van getallen \\
\hline & het maken van berekeningen met decimalen, percentages of fracties \\
\hline & gebruik van wiskunde of statistiek om berekeningen te maken \\
\hline \multirow[t]{6}{*}{ Taal vaardigheden } & het lezen en beoordelen van formulieren \\
\hline & het lezen en beoordelen van korte rapporten, brieven of memo's \\
\hline & het lezen en beoordelen van lange rapporten, brieven of memo's \\
\hline & het invullen van formulieren \\
\hline & het schrijven van korte rapporten, brieven of memo's \\
\hline & het schrijven van lange rapporten, brieven of memo's \\
\hline \multirow[t]{3}{*}{ Fysieke kracht } & fysieke kracht \\
\hline & uithoudingsvermogen \\
\hline & uw behendigheid om een taak te verrichten \\
\hline \multirow[t]{4}{*}{ Probleemoplossend vermogen } & het opmerken van fouten of problemen \\
\hline & het oplossen van problemen \\
\hline & het analyseren van problemen \\
\hline & controleren om te voorkomen dat er fouten worden gemaakt of problemen ontstaan \\
\hline \multirow[t]{2}{*}{ Plannen en organiseren } & het plannen van uw eigen werkzaamheden \\
\hline & het plannen van de werkzaamheden van anderen \\
\hline \multirow[t]{4}{*}{ Kennis van de organisatie } & kennis van het bedienen van apparaten en machines \\
\hline & kennis van specifieke producten of diensten \\
\hline & gespecialiseerde kennis of begrip die niemand anders in uw organisatie heeft \\
\hline & kennis van hoe de organisatie van uw bedrijf in elkaar zit en werkt \\
\hline \multirow[t]{4}{*}{ Gebruik van computers } & kennis van specifieke software of programmeertalen ${ }^{2)}$ \\
\hline & $\begin{array}{l}\text { het werken met een computer om bijvoorbeeld klantgegevens in te voeren en } \\
\text { rekeningen te printen }\end{array}$ \\
\hline & $\begin{array}{l}\text { het werken met een computer om documenten op te stellen, met spreadsheets te } \\
\text { werken, informatie op het internet te zoeken of e-mails te versturen }\end{array}$ \\
\hline & $\begin{array}{l}\text { het werken met een computer om producten te ontwerpen, statistische analyses uit te } \\
\text { voeren of gecompliceerde berekeningen uit te voeren }\end{array}$ \\
\hline
\end{tabular}

1) Aan respondenten is gevraagd hoe belangrijk de taken zijn op hun werk (op een schaal van 1 'helemaal niet belangrijk / niet van toepassing' tot 5'cruciaal') en hoe effectief zij in de taken zijn (op een schaal van 1 'bijna nooit' tot 5 'altijd').

2) Deze taken zijn enkel in de NSS van 2017 opgenomen en ontbreken dus in de NSS van 2012. 
TABEL A.5 Technologische en organisatorische veranderingen

\begin{tabular}{|c|c|}
\hline & Vraag uit ROA Levenslang Leren Enquête \\
\hline Technologische veranderingen & $\begin{array}{l}\text { Zijn er op uw werk technologische ontwikkelingen die de inhoud van uw werk } \\
\text { veranderen? } \\
11 \text { Helemaal niet } \\
22 \\
33 \\
44 \\
55 \text { In zeer grote mate }\end{array}$ \\
\hline Organisatorische veranderingen & $\begin{array}{l}\text { Zijn er op uw werk technologische ontwikkelingen die de inhoud van uw werk } \\
\text { veranderen? } \\
11 \text { Helemaal niet } \\
22 \\
33 \\
44 \\
55 \text { In zeer grote mate }\end{array}$ \\
\hline
\end{tabular}

FIGUUR A.1 Percentage van de werkenden dat aangeeft dat bepaalde taken (zeer) belangrijk zijn op hun werk naar geslacht, 2017

Interpersoonlijke vaardigheden

Rekenvaardigheden

Taal vaardigheden

Fysieke kracht

Probleemoplossend vermogen

Plannen en organiseren

Kennis van de organisatie

Gebruik van computers
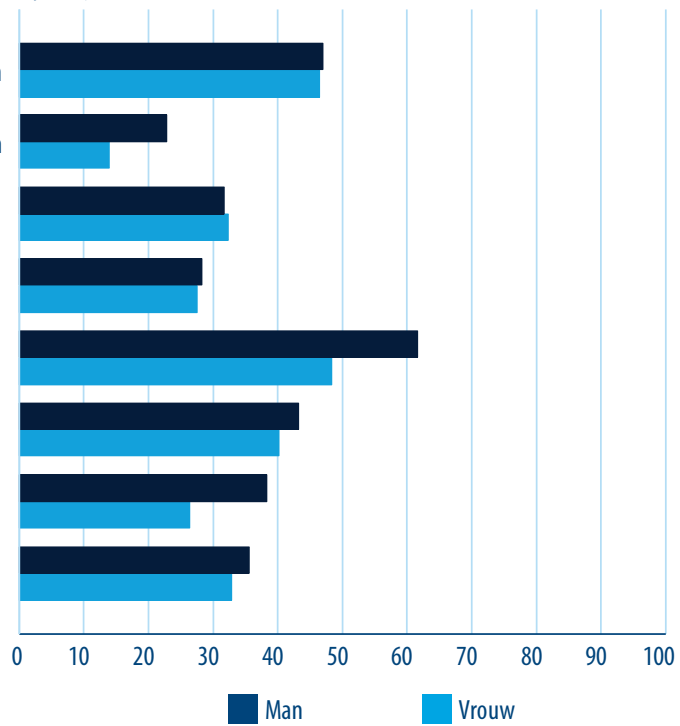
FIGUUR A.2 Percentage van de werkenden dat aangeeft dat bepaalde taken (zeer) belangrijk zijn op hun werk naar leeftijd, 2017

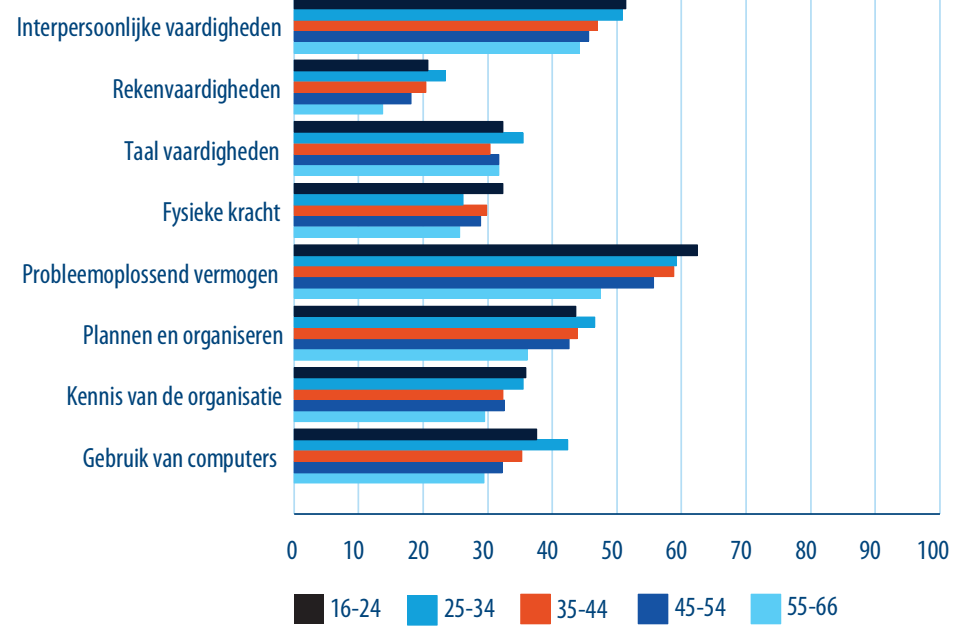




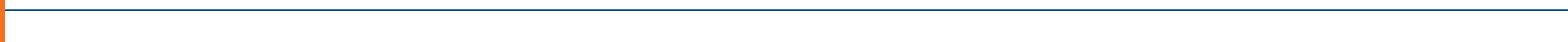




\section{BIJLAGE B}

Berekeningen achter figuren 1.7, 1.14 en 1.15

\section{Figuur 1.7}

Deze figuur laat zien hoe de totale leertijd op het werk is opgedeeld in verschillende leeractiviteiten. Hieronder vallen de leeractiviteiten cursusdeelname en informeel leren van taken op het werk. Voor beide activiteiten wordt het gemiddelde aantal uren berekend dat per jaar aan deze activiteiten is besteed. De berekeningen per activiteit dienen nader toegelicht te worden.

\section{Cursusdeelname:}

Om de leertijd als gevolg van het volgen van cursussen wordt allereerst het gemiddelde aantal gevolgde cursussen en de gemiddelde duur van een cursus in dagen en uren per dag berekend. Hierbij worden alleen de cursussen meegenomen die sinds november 2014 zijn afgerond. Vervolgens wordt het aantal gevolgde cursussen gedeeld door twee om het aantal cursussen per jaar te berekenen. Als laatste wordt dit gemiddelde aantal gevolgde cursussen per jaar vermenigvuldigd met de gemiddelde duur van een cursus in uren en dagen.

\section{Leren van taken op het werk}

Het leren van taken op het werk wordt berekend door het gemiddelde aantal gewerkte uren per jaar te vermenigvuldigen met het percentage dat een gemiddeld persoon van taken op het werk leert. Het aantal gewerkte uren is een gemiddelde van de zelf gerapporteerde arbeidsuren van de respondenten. Het percentage informeel leren is het gemiddelde antwoord dat de respondenten hebben gegeven op de vraag "Hoeveel procent van de werktijd besteedt u aan taken waarvan u kunt leren".

\section{Figuur 1.14}

Deze figuur laat zien hoe de totale leertijd van een werkende is opgedeeld in verschillende leeractiviteiten, tijdens en buiten het werk. Hierin worden alle leeractiviteiten meegenomen die in het kader van het rapport worden gedefinieerd als activiteiten waarvan men kan leren; cursusdeelname, taken op het werk, zelfstudie, vrijwilligerswerk, mantelzorg en tijd met kinderen. Wederom dienen de berekeningen per activiteit nader toegelicht te worden. Cursusdeelname en leren van taken op het werk worden overigens op dezelfde manier gedefinieerd als in Figuur 1.7. 


\section{Zelfstudie}

Met betrekking tot zelfstudie krijgen de respondenten van de ROA Levenslang Leren Enquête de vraag hoeveel uur de respondenten in de afgelopen maanden thuis hebben besteed aan zelfstudie. Vervolgens werd voor elke respondenten het aantal uur zelfstudie per jaar en het gemiddelde van alle respondenten berekend.

\section{Vrijwilligerswerk, mantelzorg en tijd met kinderen}

Voor vrijwilligerswerk, mantelzorg en tijd met kinderen wordt het gemiddelde aantal besteedde uren en het gemiddelde percentage dat men van deze tijd leert met elkaar vermenigvuldigd.

\section{Figuur 1.15}

Deze figuur laat zien hoe de totale leertijd van een werkenden en niet-werkenden is opgedeeld in verschillende leeractiviteiten, waarbij voor werkenden het tijd besteed aan taken op het werk buiten beschouwing is gelaten. Hierin worden alle leeractiviteiten meegenomen die in het kader van het rapport worden gedefinieerd als activiteiten waarvan men kan leren; cursusdeelname, zelfstudie, vrijwilligerswerk, mantelzorg en tijd met kinderen. De tijd besteed per activiteiten wordt voor deze figuur op dezelfde manier berekend als in Figuur 1.14. 